Prepared for the U.S. Department of Energy

under Contract DE-AC05-76RL01830

\title{
Plutonium and Americium Geochemistry at Hanford: A Site-Wide Review
}

KJ Cantrell

AR Felmy

\section{August 2012}

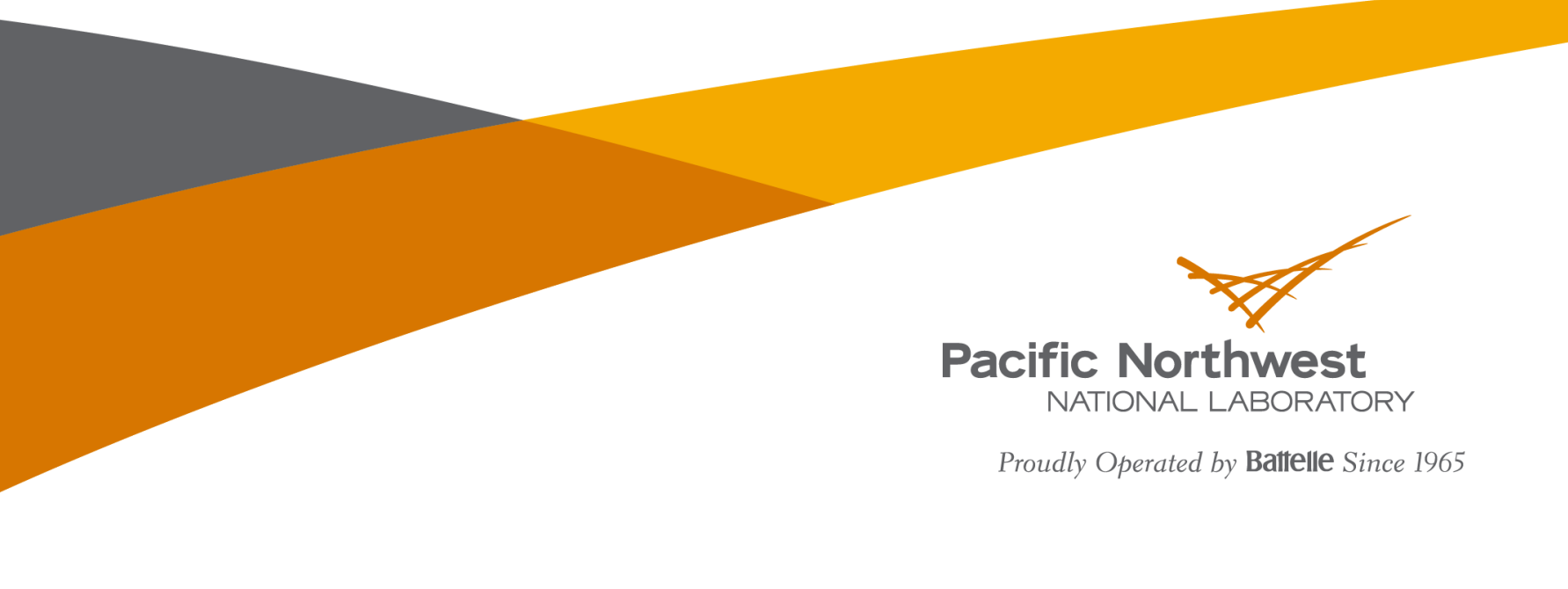




\title{
DISCLAIMER
}

This report was prepared as an account of work sponsored by an agency of the United States Government. Neither the United States Government nor any agency thereof, nor Battelle Memorial Institute, nor any of their employees, makes any warranty, express or implied, or assumes any legal liability or responsibility for the accuracy, completeness, or usefulness of any information, apparatus, product, or process disclosed, or represents that its use would not infringe privately owned rights. Reference herein to any specific commercial product, process, or service by trade name, trademark, manufacturer, or otherwise does not necessarily constitute or imply its endorsement, recommendation, or favoring by the United States Government or any agency thereof, or Battelle Memorial Institute. The views and opinions of authors expressed herein do not necessarily state or reflect those of the United States Government or any agency thereof.

\author{
PACIFIC NORTHWEST NATIONAL LABORATORY \\ operated by \\ BATTELLE \\ for the \\ UNITED STATES DEPARTMENT OF ENERGY \\ under Contract DE-AC05-76RL01830
}

Printed in the United States of America
Available to DOE and DOE contractors from the Office of Scientific and Technical Information, P.O. Box 62, Oak Ridge, TN 37831-0062; ph: (865) 576-8401 fax: $(865) 576-5728$
email: reports $a$ adonis.osti.gov
Available to the public from the National Technical Information Service 5301 Shawnee Rd., Alexandria, VA 22312 ph: (800) 553-NTIS (6847)

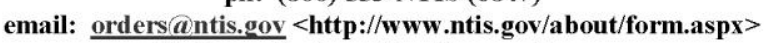 Online ordering: http://www.ntis.gov




\section{Plutonium and Americium Geochemistry at Hanford: A Site-Wide Review}

KJ Cantrell

AR Felmy

August 2012

Prepared for the U.S. Department of Energy under Contract DE-AC05-76RL01830

Pacific Northwest National Laboratory

Richland, Washington 99352 


\section{Executive Summary}

This report was produced to provide a systematic review of the state-of-knowledge of plutonium and americium geochemistry at the Hanford Site. The report integrates existing knowledge of the subsurface migration behavior of plutonium and americium at the Hanford Site with available information in the scientific literature regarding the geochemistry of plutonium and americium in systems that are environmentally relevant to the Hanford Site. As a part of the report, key research needs are identified and prioritized, with the ultimate goal of developing a science-based capability to quantitatively assess risk at sites contaminated with plutonium and americium at the Hanford Site and the impact of remediation technologies and closure strategies.

Spent fuel was reprocessed at the Hanford Site from 1944 through 1989 for production of plutonium for nuclear weapons (Gephart 2010). Over the lifetime of the Hanford facilities, 96,900 metric tons of uranium in the form of spent fuel was reprocessed to recover 67.4 metric tons of plutonium $\left(4.2 \times 10^{6} \mathrm{Ci}\right)$ (Gephart 2010). After product removal, $3.37 \times 10^{4} \mathrm{Ci}$ of plutonium-239, 8.11 $\times 10^{3} \mathrm{Ci}$ of plutonium-240, $1.27 \times 10^{5} \mathrm{Ci}$ of plutonium-241, and $8.27 \times 10^{4} \mathrm{Ci}$ of americium-241 remained in waste streams (Corbin 2005; Watrous et al. 2002). Wastes generated early in the development (pre 1973) were intentionally disposed to the near-surface environment at the Hanford Site. Over the entire production period most of these wastes $(65 \%)$ were disposed to single- and double-shelled tanks.

It is estimated that $11,800 \mathrm{Ci}(189 \mathrm{~kg})$ of plutonium-239; $2,900 \mathrm{Ci}(12.6 \mathrm{~kg})$ of plutonium-240; $37,500 \mathrm{Ci}(0.34 \mathrm{~kg})$ of plutonium-241; 28,700 Ci (9.0 kg) americium-241; and $55 \mathrm{Ci}(78 \mathrm{~kg})$ neptunium-237 were disposed across the Hanford Site (Cantrell 2009). These wastes were primarily liquid process wastes disposed to constructed waste disposal facilities such as trenches, cribs, and ponds. The vast majority of transuranic contaminants disposed to the vadose zone on the Hanford Site $(10,200 \mathrm{Ci}$ [86\%] of plutonium-239; 2,560 Ci [88\%] of plutonium-240; 33,100 Ci [88\%] of plutonium-241; 27,900 $\mathrm{Ci}$ [97\%] of americium-241; and 41.8 Ci [78\%] of neptunium-237) were disposed at sites within the Plutonium Finishing Plant closure zone.

The significance of plutonium-241 is noteworthy and often overlooked due to its short half-life (14.3 years, see Table 1.1). For example, a re-analysis of a study conducted by Price et al. (1979) on the 216-Z-1A Crib demonstrated that plutonium-241 co-disposed with plutonium-239/240 in acidic high-salt wastes resulted in the in growth and subsequent mobilization of americium-241 relative to the plutonium isotopes. Because americium-241 is the daughter product of radioactive decay of plutonium-241 and has a much longer half-life than plutonium-241, plutonium-241 is a continuing source of americium-241. As a result, the activity of americium- 241 will increase in the vadose zone over the short term (approximately next 50 years). In addition, the activity of plutonium-241 disposed to the vadose zone at the Hanford Site is substantially greater than that of plutonium-239 and plutonium-240 combined. Decayed to January 1 , 2001, the activity ratio of plutonium-241 to the sum of plutonium-239 and plutonium-240 disposed to the vadose zone was 2.6 .

From analyses of the various waste sites within the Plutonium Finishing Plant closure zone, it was concluded that these sites can be classified into two major categories based primarily upon the type of wastes that were received by the site (Cantrell and Riley 2008). The two waste categories are low-salt near-neutral wastes and acidic high-salt waste with which organic complexants were co-disposed (Cantrell et al. 2003). At some waste sites where plutonium- and americium-rich wastes were disposed, 
measureable concentrations of both plutonium and americium have reached considerable depths within the vadose zone (in excess of $40 \mathrm{~m}$ below ground surface) for both waste types. In general, much higher concentrations of plutonium and americium were transported deep into the vadose zone at sites that received acidic high-salt waste co-disposed with organic solvents.

Under environmental conditions relevant to the Hanford Site, americium occurs primarily in the +3 oxidation state, whereas plutonium can occur in multiple oxidation states $(+3,+4,+5$, and +6$)$. Oxidation state can significantly impact complexation with dissolved ligands, solubility, and sorption. As a result, the mobility of americium can be different than that of plutonium and these differences can be significantly impacted by local redox chemistry. The nature of the decay chain of plutonium-241 (discussed above) is such that the disposal history of a particular site and the chemistry of the disposed wastes can impact the degree of separation that can occur between plutonium and americium-241. For example, at the 216-B-5 Reverse Well, it was shown that the majority of americium-241 that is in the vadose zone was emplaced as plutonium-241 along with low-salt near-neutral wastes. As a result, the distribution of americium-241 is very similar to that of plutonium-239/240 at this site. At the 216-Z-1A Tile Field, the majority of plutonium was disposed as acidic actinide-bearing wastes over a 5-year period. Over the course of waste disposal, a fraction of plutonium-241 emplaced early in this 5-year period decayed to americium-241. During subsequent disposal of acidic waste solutions, it appears that americium-241 was preferentially mobilized relative to plutonium, resulting in an observable separation of americium-241 from plutonium-239/240 within the depth profiles below the 216-Z-1A Crib.

Despite the very large quantities of plutonium-239 bearing waste that were disposed to the vadose zone at the Hanford Site, plutonium is regularly detected at concentrations at or near the maximum concentration limit $(15 \mathrm{pCi} / \mathrm{L})$ in only three wells. All three of these wells are located within a few meters of the 216-B-5 Reverse Well, where wastes containing plutonium were directly injected into the Hanford aquifer from 1945 through 1947. Trends in these wells indicate that plutonium concentrations are not increasing.

The precipitation of plutonium and americium in Hanford Site sediments is linked to the concentrations in the disposed solutions, oxidation state (plutonium), the acidity or $\mathrm{pH}$ of the discharge solutions, presence of ligands (such as $\mathrm{PO}_{4}$ ) that can form solid phases, and changes in chemistry that can occur when waste solutions contact subsurface sediments. In this regard, the acidic wastes discharged to the 216-Z-9 Trench, the 216-Z-1A Crib, and the 216-Z-18 Crib are examples of disposal sites where precipitation of plutonium, and possibly americium, solids would occur as the acid waste solutions contact the underlying sediments. The precipitation of this "nonparticulate plutonium" appears to be linked with the dissolution of basic minerals (such as carbonates or feldspars) present in the sediments which can create higher $\mathrm{pH}$ regions in the local chemical environments near the mineral surfaces. Earlier reports (Ames 1974; Price et al. 1979) indicated that the chemical form of the precipitated plutonium was most likely plutonium polymer or amorphous plutonium hydroxide. However, recent analysis of the Z-9 surface sediments by Batuk et al. (2012) and Buck et al. (2012) indicates that a significant fraction of the precipitated plutonium could have occurred as plutonium phosphates or plutonium phosphates/silicates. The source of the phosphate in the waste solution is not precisely known, but thermal, radiolytic, and microbial breakdown of tributyl phosphate or dibutyl phosphate are likely. Results of thermodynamic modeling are generally consistent with these observations, indicating that under typical uncontaminated Hanford Site vadose zone or groundwater conditions, the solubility of hydrated $\mathrm{PuO}_{2}$ will control plutonium concentrations. At waste sites where significant phosphate may be available, the solubility of $\mathrm{PuPO}_{4}($ hyd) may control plutonium concentrations for low Eh conditions and moderately alkaline $\mathrm{pH}$ 
values to moderately acidic $\mathrm{pH}$ values. For very acidic and oxidizing conditions, the solubility of $\mathrm{Pu}\left(\mathrm{HPO}_{4}\right)_{2}(\mathrm{~s})$ may control plutonium concentrations.

The possibility of americium precipitation in Hanford Site sediments has never been established. In general, Am(III) is relatively soluble over a wide range of $\mathrm{pH}$ values in the absence of other ligands. However, in the presence of phosphate, americium forms highly insoluble $\mathrm{AmPO}_{4}$ analogous to $\mathrm{PuPO}_{4}$. Hence, the precipitation of $\mathrm{AmPO}_{4}$ or the substitution of americium into plutonium phosphate compounds could have occurred at acid waste disposal sites. However, no evidence of such formation reactions currently exists. Americium can also form insoluble americium carbonate compounds, such as $\mathrm{AmOHCO}_{3}$, at circumneutral $\mathrm{pH}$ values but again no evidence for the formation of such compounds in Hanford Site sediments exits.

When plutonium and americium concentrations are below the solubility limits of applicable solubility controlling phases, adsorption to mineral surfaces can be important. Adsorption is particularly important in the far field region of a waste site. The degree of adsorption can vary considerably and is dependent upon oxidation state (for plutonium), $\mathrm{pH}$, complexation with dissolved ligands, and mineral surface type and surface area. Some of the more important minerals that can adsorb plutonium and americium include various metal oxides (iron oxides, manganese oxides, aluminum oxides), clay minerals, calcite, and silica. All of these minerals occur in Hanford sediments.

The significance of colloidal transport of plutonium and americium within the Hanford vadose zone where significant amounts of plutonium and americium wastes were disposed remains unclear. Based on data from a single study, it appears that for typical far-field conditions, colloidal transport through Hanford groundwater is not an important transport mechanism. The situation for waste sites significantly impacted by plutonium processing wastes is much less certain. Several lines of evidence suggest that colloidal transport may have played a role in the migration of plutonium through the vadose zone beneath waste sites during periods of active disposal. These include that fact that acidic wastes containing plutonium and americium can produce colloidal particles during acid induced weathering of sedimentary minerals in the vadose zone. Adsorption of plutonium and americium to these nascent particles and subsequent advection deeper into the vadose zone could have potentially served as a transport mechanism during active disposal. Recent studies provide evidence of the presence of nano-sized particles of plutonium precipitates of variable composition in sediment samples collected below the 216-Z-9 Trench; however, it is unclear if these particles precipitated in situ or were transported as colloidal particles. The potential for remobilization of these particles during future closure scenarios is unknown.

In order to demonstrate to regulators and other interested parties that we have a technically defensible understanding of plutonium and americium behavior in the Hanford environment, and to predict the impact of remediation or closure options with reasonable confidence, a number of unresolved issues and research needs and challenges need to be addressed. The two primary issues that need to be resolved are 1) what was the mechanism responsible for migration of plutonium and americium into the deep subsurface at disposal sites in the Hanford 200 West Area, and 2) can plutonium and americium present at Hanford disposal sites be re-mobilized into subsurface groundwaters? To address these issues, three research challenges were identified, these are:

1. Determine the transformations of Hanford Site sediments in response to changes in waste/ groundwater composition. Significant mineralogical transformations can that take place when acidic wastes contact Hanford sediments. These transformations can significantly impact the solubility and 
adsorption of plutonium and americium and possibly result in the generation of pseudo colloids that could facilitate plutonium/americium migration.

2. Assess the impact of changes in waste/groundwater chemistry on the potential for plutonium/americium solubilization or colloid formation. Changes in waste or groundwater chemistry can greatly impact the chemical form or speciation of plutonium and americium.

Knowledge of plutonium and americium speciation will be crucial in terms of evaluating the potential for solubilization, adsorption or remobilization of adsorbed complexes, colloid formation, and colloid interactions with sedimentary minerals.

3. Establish the role of organic complexants and/or non-aqueous solvents in the transport of plutonium/americium in the deep subsurface. Plutonium has been found to be associated with TBP and the presence of non-aqueous solvents, at least in certain Z-9 sediments. It will be important to establish the role of non-aqueous solvent in past movement of plutonium and its potential role in future mobility. 


\section{Acknowledgments}

This document was prepared by the Deep Vadose Zone- Applied Field Research Initiative at Pacific Northwest National Laboratory. Funding for this work was provided by the U.S. Department of Energy Richland Operations Office. The Pacific Northwest National Laboratory is operated by Battelle Memorial Institute for the U.S. Department of Energy under Contract DE-AC05-76RL01830. The authors greatly appreciate the technical reviews provided by RJ Serne, MB Triplett, EC Buck, RM Smith, EC Golovich, and DM Wellman (Pacific Northwest National Laboratory [PNNL]). We are particularly grateful to KR Neiderhiser (PNNL) for the word processing of this technical report. 



\section{Acronyms and Abbreviations}

$\begin{array}{ll}\text { bgs } & \text { below ground surface } \\ \text { EPA } & \text { U.S. Environmental Protection Agency } \\ \text { DBP } & \text { dibutyl phosphate } \\ \text { DBBP } & \text { dibutylbutyl phosphonate } \\ \text { DNAPL } & \text { dense nonaqueous phase liquid } \\ \text { DOE } & \text { U.S. Department of Energy } \\ \text { EDTA } & \text { ethylenediaminetetraacetic acid } \\ \text { HEXS } & \text { high energy x-ray source } \\ \text { IUPAC } & \text { International Union of Pure and Applied Chemistry } \\ \text { K } & \text { distribution coefficient } \\ \text { MBP } & \text { monobutyl phosphate } \\ \text { MCL } & \text { maximum concentration limit } \\ \text { nanoSIMS } & \text { nano Secondary Ion Mass Spectrometry } \\ \text { NMR } & \text { nuclear magnetic resonance } \\ \text { OU } & \text { operable unit } \\ \text { PFP } & \text { Plutonium Finishing Plant } \\ \text { PNNL } & \text { Pacific Northwest National Laboratory } \\ \text { ppm } & \text { parts per million } \\ \text { PUREX } & \text { Plutonium Uranium Extraction (Plant or process) } \\ \text { RECUPLEX } & \text { Recovery of Uranium and Plutonium by Extraction (Plant or process) } \\ \text { REDOX } & \text { Reduction-Oxidation (Plant or process) } \\ \text { SIM } & \text { Soil Inventory Model } \\ t_{1 / 2} & \text { half-life } \\ \text { TEM } & \text { transmission electron microscopy } \\ \text { TBP } & \text { x-ray absorption fine structure } \\ \text { XAFS } & \text { X-ray absorption spectroscopy } \\ \text { XAS } & \end{array}$





\section{Units of Measure}

$\begin{array}{ll}\mathrm{Bq} / \mathrm{l} & \text { becquerel/liter } \\ \mathrm{Ci} & \text { curie(s) } \\ \mathrm{ft} & \text { foot; feet } \\ \mathrm{g} & \text { gram(s) } \\ \mathrm{kg} & \text { kilogram(s) } \\ \mathrm{L} & \text { liter(s) } \\ \mathrm{lb} & \text { pound(s) } \\ \mu & \left.\text { micro (prefix, } 10^{-6}\right) \\ \mu \mathrm{Ci} & \text { microcurie(s) }\left(10^{-6} \mathrm{Ci}\right) \\ \mathrm{m} & \text { meter(s) } \\ \mathrm{M} & \text { molar }(\operatorname{moles} / \mathrm{L}) \\ \mathrm{ML} & \text { megaliter(s) }\left(10^{6} \mathrm{~L}\right) \\ \mathrm{nCi} & \text { nanocurie(s) }\left(10^{-9} \mathrm{Ci}\right) \\ \mathrm{nm} & \text { nanometer(s) } \\ \mathrm{pCi} & \text { picocurie(s) }\left(10^{-12} \mathrm{Ci}\right) \\ \mathrm{wt} \% & \text { weight percent }\end{array}$





\section{Contents}

Executive Summary ….................................................................................................. iii

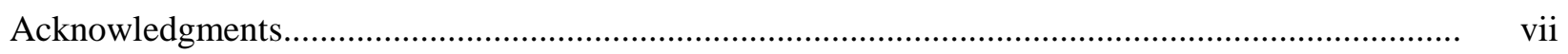

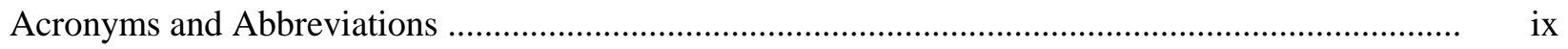

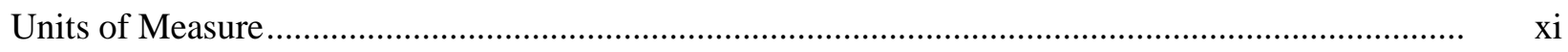

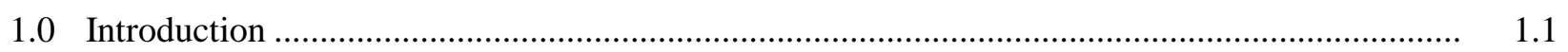

2.0 Inventory and Character of Plutonium/Americium Containing Wastes ................................... 2.1

3.0 Insights Acquired from Field and Laboratory Studies of Hanford Plutonium/Americium

Waste Sites .......................................................................................................... 3.1

3.1 Direct Injection of Plutonium Bearing Waste into Groundwater through

216-B-5 Reverse Well ...................................................................................... 3.1

3.2 Plutonium and Americium at the 200-PW-1/3/6 Operable Units .................................... 3.4

3.2.1 Background and History of Plutonium and Americium Contamination at the 216-Z-9 Trench ..................................................................................... 3.5

3.2.2 Soil Analysis Results from Wells 299-W15-46 and 299-W15-48 ......................... 3.7

3.2.3 Plutonium Mobility Studies on 216-Z-9 Trench Samples..................................... 3.12

3.2.4 Distribution of Plutonium and Americium Below the 216-Z-1A Tile Field............ 3.14

3.2.5 Comparison of Key Site Features of Sites Receiving Acidic High-Salt Wastes and Low-Salt Near-Neutral Wastes ....................................................... 3.14

3.3 Historic Site-Wide Monitoring of Plutonium in Groundwater.......................................... 3.17

3.4 Summary and Implications of Past Studies ............................................................... 3.18

4.0 Speciation and Solubility of Plutonium and Americium in the Hanford Environment ............... 4.1

4.1 Speciation and Solubility of Plutonium......................................................................... 4.1

4.1.1 Plutonium Disproportionation Reactions .......................................................... 4.2

4.1.2 Plutonium Speciation and Solubility Calculations Relevant to Hanford ................. 4.3

4.1.3 Hyperstoichiometric Plutonium Oxide........................................................... 4.7

4.2 Speciation and Solubility of Americium ..................................................................... 4.7

4.2.1 Americium Speciation and Solubility Calculations Relevant to Hanford ................ 4.7

4.3 Organo-Phosphates and Phosphonates and Implications for Plutonium and

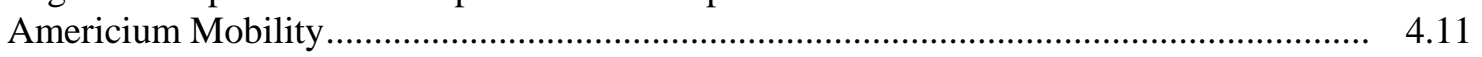

4.3.1 Aqueous Phase Transport ............................................................................. 4.11

4.3.2 Organic Phase Transport ............................................................................... 4.12

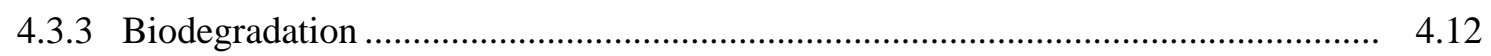

4.4 Importance of Precipitation and Mass-Transfer Processes .............................................. 4.13

5.0 Adsorption and Surface Complexation........................................................................ 5.1

5.1 Hanford-Specific Plutonium and Americium Distribution Coefficient Data...................... 5.2

5.2 Surface Complexation of Plutonium ............................................................................ 5.3

5.3 Surface Complexation of Americium...................................................................... 5.5

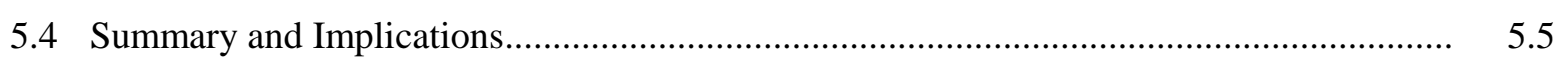




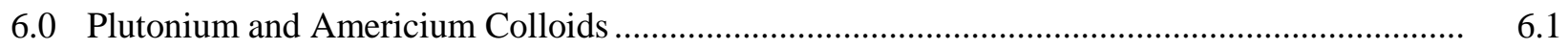

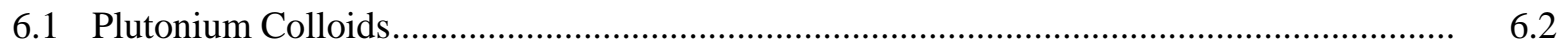

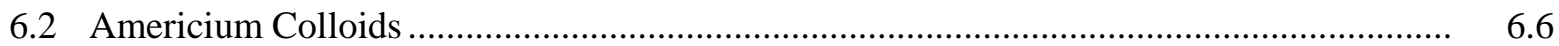

6.3 Implications of Plutonium and Americium Colloids.................................................... 6.8

7.0 Challenges and Research Needs .......................................................................................

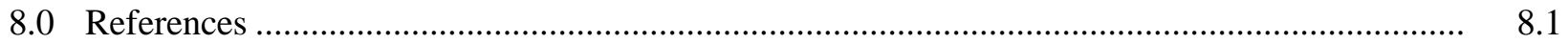

\section{Figures}

1.1 Hanford Site Geography and Major Operational Areas

3.1 Cross-Section of Plutonium-239/240 Distribution in the Vicinity of the 216-B-5 Reverse Well

3.2 Plutonium-239/240 and Americium-241 in Sediment Collected from Well 299-E28-23 .......... 3.3

3.3 Plutonium 239/240 Extracted from 216-B-5 Reverse Well During Treatability Testing .......... 3.4

3.4 Map of 216-Z-9 Trench and Vicinity Including Wells 299-W15-46 and 299-W15-48 ............ 3.5

3.5 Plutonium, Americium, and TBP Concentrations as a Function of Depth Measured in Soil Samples from Well 299-W15-46.

3.6 Plutonium, Americium, and $\mathrm{pH}$ as a Function of Depth Measured in Soil Samples from Well 299-W15-46.

3.7 Nitrate Concentrations as a Function of Depth Measured in Soil Samples from Wells 299-W15-46 and 299-W15-48

3.8 Plutonium, Americium, and TBP Concentrations as a Function of Depth Measured in Soil Samples from Well 299-W15-48.

3.9 North-South Cross Section Through the Center of the 216-Z-1A Tile Field and Distribution of Waste, and Plan View of 216-Z-1A Tile Field and Distribution of Waste

3.10 Plutonium-239/240, Americium-241 and Americium-241/Plutonium-239/240 Ratio in Sediment Collected from Well 299-W18-149

3.11 Trends in Plutonium Groundwater Concentrations near the 216-B-5 Reverse Well Injection Site, Includes Filtered and Unfiltered Samples

4.1 Eh pH Diagram for Plutonium at a Concentration of $10^{-12} \mathrm{M}$ in Pure Water

4.2 Eh pH Diagram for Plutonium at a Concentration of $10^{-10} \mathrm{M}$ in Pure Water

4.3 Eh pH Diagram for Plutonium at a Concentration of $10^{-10} \mathrm{M}$ in a Hypothetical Hanford Site Groundwater with a Composition of $2 \times 10^{-3} \mathrm{M} \mathrm{HCO}_{3}^{-}, 10^{-3} \mathrm{M} \mathrm{Cl}^{-}$, $5 \times 10^{-4} \mathrm{M} \mathrm{SO}_{4}{ }^{2-}, 10^{-6} \mathrm{M} \mathrm{HPO}_{4}{ }^{2-}, 10^{-3} \mathrm{M} \mathrm{Na}^{+}, 2 \times 10^{-3} \mathrm{M} \mathrm{Ca}^{2+}$, and $5 \times 10^{-4} \mathrm{M} \mathrm{Mg}^{2+}$

4.4 Eh pH Diagram for Plutonium at a Concentration of $10^{-10} \mathrm{M}$ in a Hypothetical Hanford Site Groundwater with a Composition of $2 \times 10^{-3} \mathrm{M} \mathrm{HCO}_{3}^{-}, 10^{-3} \mathrm{M} \mathrm{Cl}^{-}$, $5 \times 10^{-4} \mathrm{M} \mathrm{SO}_{4}{ }^{2-}, 10^{-5} \mathrm{M} \mathrm{HPO}_{4}{ }^{2-}, 10^{-3} \mathrm{M} \mathrm{Na}^{+}, 2 \times 10^{-3} \mathrm{M} \mathrm{Ca}^{2+}$, and $5 \times 10^{-4} \mathrm{M} \mathrm{Mg}^{2+}$

4.5 Distribution of Americium Species at a Concentration of $10^{-12} \mathrm{M}$ in Pure Water 
4.6 Distribution of Americium Species at a Concentration of $10^{-12} \mathrm{M}$ in a Hypothetical Hanford Site Groundwater with a Composition of $2 \times 10^{-3} \mathrm{M} \mathrm{HCO}_{3}^{-}, 10^{-3} \mathrm{M} \mathrm{Cl}^{-}$, $5 \times 10^{-4} \mathrm{M} \mathrm{SO}_{4}{ }^{2-}, 10^{-6} \mathrm{M} \mathrm{HPO}_{4}{ }^{2-}, 10^{-3} \mathrm{M} \mathrm{Na}^{+}, 2 \times 10^{-3} \mathrm{M} \mathrm{Ca}^{2+}$, and $5 \times 10^{-4} \mathrm{M} \mathrm{Mg}^{2+}$

4.7 Solubility of Americium Phases in a Hypothetical Hanford Site Groundwater with a Composition of $2 \times 10^{-3} \mathrm{M} \mathrm{HCO}_{3}^{-}, 10^{-3} \mathrm{M} \mathrm{Cl}^{-}, 5 \times 10^{-4} \mathrm{M} \mathrm{SO}_{4}{ }^{2-}, 10^{-3} \mathrm{M} \mathrm{Na}^{+}$, $2 \times 10^{-3} \mathrm{M} \mathrm{Ca}^{2+}$, and $5 \times 10^{-4} \mathrm{M} \mathrm{Mg}^{2+}$, Shaded Area Indicates Approximate

Range of Uncontaminated Hanford Groundwater and Pore Water.

4.8 Solubility of Americium Phases in a Hypothetical Hanford Site Groundwater with a Composition of: $2 \times 10^{-3} \mathrm{M} \mathrm{HCO}_{3}^{-}, 10^{-3} \mathrm{M} \mathrm{Cl}^{-}, 5 \times 10^{-4} \mathrm{M} \mathrm{SO}_{4}{ }^{2-}, 10^{-6} \mathrm{M} \mathrm{HPO}_{4}{ }^{2-}$, $10^{-3} \mathrm{M} \mathrm{Na}^{+}, 2 \times 10^{-3} \mathrm{M} \mathrm{Ca}^{2+}$, and $5 \times 10^{-4} \mathrm{M} \mathrm{Mg}^{2+}$, Shaded Area Indicates Approximate Range of Uncontaminated Hanford Groundwater and Pore Water.

6.1 The Elemental Mapping of 216-Z-9 Crib Surface Sample and Results of a Curve Fitting for a Shell at 3.45-3.54 $\AA$ Using Both Pu-O and Pu-P Amplitudes and Phases Compared to the Data

6.2 Thin-Sectioned 216-Z-9 Crib Sediment Showing the Occurrence of a PlutoniumPhosphate Region Within a Clay-Like Phase

6.3 NanoSIMS and SEM Images of Individual Soil Particles Collected from Well 299-W15-48, Sample B1HY61, Collected at Sample Depths of 65-66 ft bgs. Plutonium appears to be concentrated at grain boundaries on these samples.

6.4 NanoSIMS and SEM Images of Individual Soil Particles Collected from Well 299-W15-48, Sample B1HY61, Collected at Sample Depths of 65-66 ft bgs. Plutonium appears to be concentrated in $\mathrm{CaCO}_{3}$ precipitates.

6.5 Plutonium and Americium Distributions in Well 299-W18-181 as a Function of Depth

\section{Tables}

1.1 Plutonium and Americium Isotopes of Environmental Concern at the Hanford Site

2.1 Hanford Waste Sites with Estimated Plutonium-239 Inventories in Excess of $25 \mathrm{Ci}$, Decayed to January 1, 2001

2.2 Operating Years, Volumes Disposed, and Waste Types for Waste Sites with Estimated Plutonium-239 Inventories in Excess of $25 \mathrm{Ci}$, Decayed to January 1, 2001

3.1 Maximum Concentration and Depth Interval for Plutonium-239/240, Americium-241, TBP, and Lowest $\mathrm{pH}$ Value and Depth Interval, Well 299-W15-46

3.2 Maximum Concentration and Depth Interval for Plutonium-239/240, Americium-241, and TBP, Well 299-W15-48

3.3 Summary of Key Waste Site Features for Two Representative Highly Impacted Waste Sites of the 200-PW-1 Operable Unit

3.4 Number of Wells Sampled and Distinct Sample Results for Plutonium and Gross Alpha during 2010 and 2011

4.1 Plutonium Thermodynamic Data Used in Speciation and Solubility Calculations

4.2 Americium Thermodynamic Data Used in Speciation and Solubility Calculations...

5.1 Surface Complexation Model for Plutonium Adsorption onto Geothite and Silica 


\subsection{Introduction}

The Hanford Site was constructed during the Manhattan Project for the industrial-scale production of plutonium for use in nuclear weapons (DOE/EM 1997; DOE/RL 2002). A massive industrial complex was required to accomplish this task. The site location (Figure 1.1) was selected for its relative remoteness and sparse population for safety and security reasons. Between 1943 and 1963, nine reactors were constructed on the site. Uranium fuel fabrication facilities were built in the 300 Area, along with research and development laboratories. Chemical separations plants for the recovery of plutonium from irradiated fuel rods were constructed in the 200 East and 200 West Areas. From 1945 until 1949, the plutonium nitrate coming from the chemical separations facilities was shipped offsite for conversion into plutonium metal and weapons components. In 1949, the 234-5Z Facility (commonly referred to as the Z Plant Complex, Z Plant, or Plutonium Finishing Plant [PFP]) began operations in the 200 West Area to convert plutonium nitrate from the 231-Z Plutonium Isolation Facility into metal and metal components. The 231-Z Facility operated until the bismuth phosphate process operations in the T Plant ended in 1956 when the plutonium-uranium extraction (PUREX) process came on line.

In 1955, the Recovery of Uranium and Plutonium by Extraction (RECUPLEX) process came on line in the Z Plant to serve as a versatile plutonium recovery operation. The RECUPLEX process used a PUREX-type solvent extraction system where tributyl phosphate (TBP) was used as the extractant and carbon tetrachloride as the diluent (rather than normal paraffin hydrocarbon, which was used in the PUREX Plant). The RECUPLEX process was shut down in April 1962 and was replaced by the 236-Z Plutonium Reclamation Facility in May 1964. Both facilities used similar chemical separations technologies and produced similar waste streams. A more complete history of the development of the Z Plant Complex can be found in HNF (1997) and SGW (2009).

Plutonium-239 is a long-lived isotope of an element of great human health and environmental concern. Americium-241 is the decay product of plutonium-241 and is also of significant environmental concern. Table 1.1 shows plutonium and americium isotopes of environmental interest at the Hanford Site, along with their half-lives ( $\left.\mathrm{t}_{1 / 2}\right)$ (Unterweger et al. 1992). Other isotopes such as plutonium-242 $\left(\mathrm{t}_{1 / 2}=\right.$ $\left.3.73 \times 10^{5} \mathrm{y}\right)$, americium-243 $\left(\mathrm{t}_{1 / 2}=7,370 \mathrm{y}\right)$, neptunium-237 $\left(\mathrm{t}_{1 / 2}=2.14 \times 10^{6} \mathrm{y}\right)$, and curium isotopes (curium-242, $-243,-244$ with longest $t_{1 / 2}=29.1 \mathrm{y}$ ) were also produced in the irradiated fuels but at much lower activities than the isotopes listed in Table 1.1. Most of the plutonium production at the Hanford Site occurred between 1950 and 1970 (Gephart 2010).

Table 1.1. Plutonium and Americium Isotopes of Environmental Concern at the Hanford Site

\begin{tabular}{cc}
\hline Isotope & Half-Life \\
\hline Plutonium-238 & 87.7 years \\
Plutonium-239 & 24,110 years \\
Plutonium-240 & 6,561 years \\
Plutonium-241 & 14.3 years \\
Americium-241 & 433 years \\
\hline
\end{tabular}




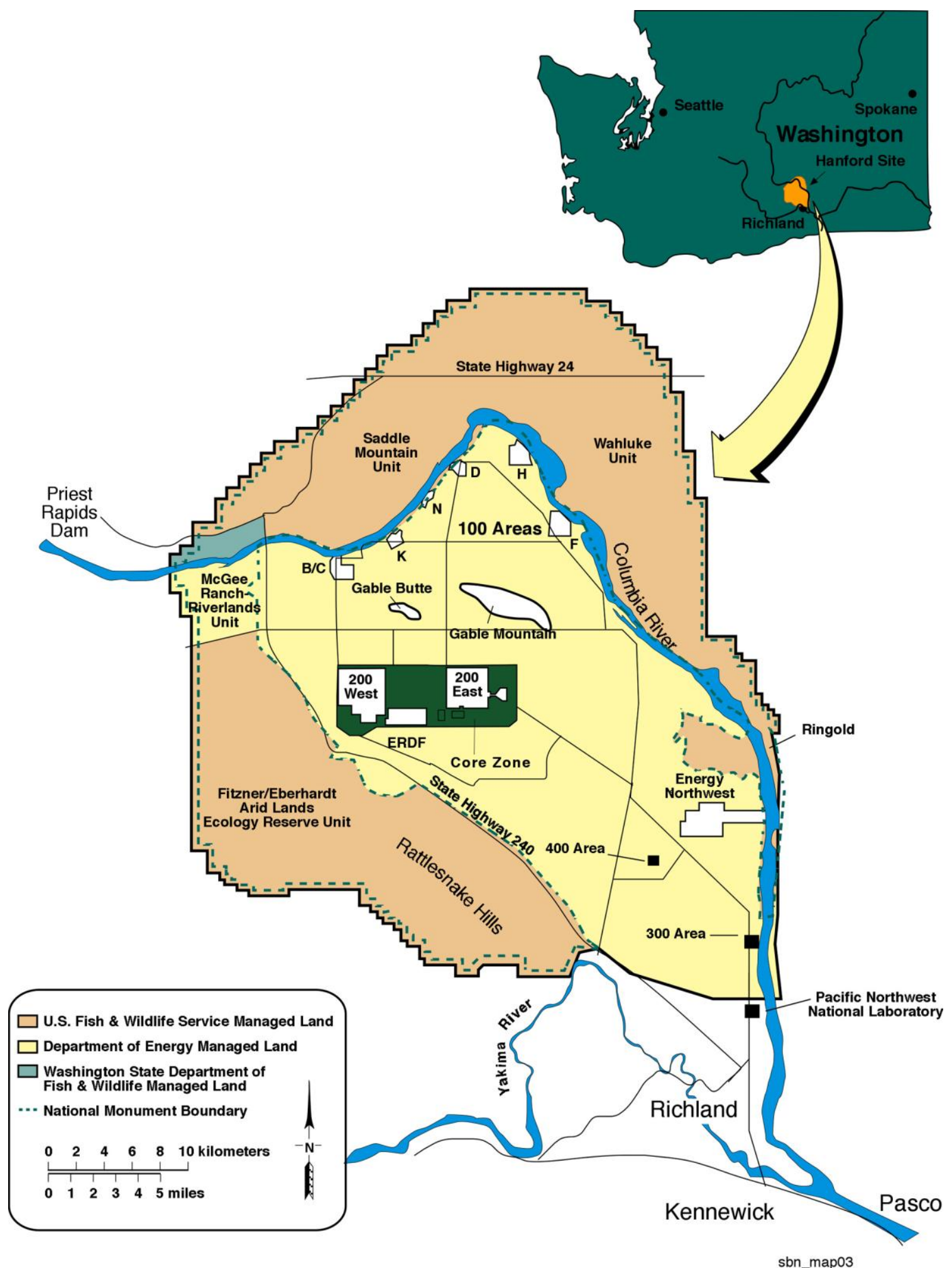

Figure 1.1. Hanford Site Geography and Major Operational Areas 
It is estimated that $11,800 \mathrm{Ci}(189 \mathrm{~kg})$ of plutonium-239 and 28,700 $\mathrm{Ci}$ americium-241 were disposed directly to the vadose zone as liquid wastes across the Hanford Site (Cantrell 2009). The vast majority of plutonium and americium disposed to the vadose zone on the Hanford Site (10,200 Ci [86\%] of plutonium-239 and 27,900 Ci [97\%] of americium-241) was disposed to sites within the PFP closure zone in the 200 West Area. Under typical Hanford Site vadose zone conditions, plutonium and americium are not very mobile, due to their low solubility and strong tendency to sorb to mineral surfaces. However, there are a few sites at Hanford where plutonium and americium have migrated considerable distances (up to 120 feet below ground surface [bgs]) through the vadose zone. At these sites, plutonium and americium were disposed as acidic liquid wastes and with organic extractants (TBP). The observed migration has brought into question our ability to thoroughly understand the risk associated with these sites. Indeed, the chemistry of the actinide elements, plutonium in particular is exceedingly complex. For example, under environmentally relevant conditions plutonium occurs in four different oxidation states, each of which behave very differently than the others. In addition, these four oxidation states can co-exist simultaneously in the same solution (Cleveland 1979). Another important complication of plutonium geochemistry is the formation of intrinsic and pseudo colloids. ${ }^{1}$ Colloids have the potential to play a major role in the mobility of plutonium in the environment and have been implicated by a number of researchers as being responsible for mobilizing plutonium at a number of sites where this would not necessarily be expected. However, the impact of colloids on plutonium migration remains poorly understood.

Two recent publications have raised questions on the status of plutonium waste within the U.S. Department of Energy (DOE) complex (Alvarez 2011; International Panel on Fissile Materials 2010). Between 1996 and the present these two publications note that there has been a significant increase in the mass of plutonium designated as waste in DOE publications. The increase appears to be due to: 1) reclassification of residues originally set aside for plutonium recovery for weapons as waste; 2) underestimates of production losses; and 3) improvements in waste characterization data. Because the Hanford Site is responsible for nearly a third of DOE's plutonium wastes (4 metric tons) - more than any site in the U.S. nuclear weapons complex - the two cited publications suggest that the status of plutonium waste at Hanford merits renewed attention.

The two publications indicate that prior to 1970, when most of U.S. plutonium production occurred, material measurement technologies "were less accurate than today." In recent years, environmental compliance agreements with host states have resulted in more rigorous measurements of plutonium in wastes, which, in some cases, has resulted in dramatic increases. For example the amount of plutonium in Hanford high-level radioactive waste tanks has been found to be more than twice the amount estimated in 1996. ${ }^{2}$ Another example of increased plutonium waste inventories is the 216-Z-9 Trench. Although historical processing records indicate that approximately $27 \mathrm{~kg}$ of plutonium were discarded into the trench between 1955 and 1962, sediment samples taken in the years following closure of the 216-Z-9 Trench indicate that it may have contained as much as $150 \mathrm{~kg}$ of plutonium, with soil plutonium concentrations as high as $34.5 \mathrm{~g} / \mathrm{L}$-soil at the bottom of the trench. Between 1974 and 1976, $58 \mathrm{~kg}$ of

\footnotetext{
${ }^{1}$ Intrinsic colloids (sometimes called real, pure, or true colloids) are primarily composed of actinides formed through condensation by hydrolytic or precipitation processes. Pseudo colloids (or associative colloids) are colloids in which trace amounts of actinides adsorb to naturally occurring colloids that consist of various minerals, clays and oxides, partially coated with organic matter, and organic macromolecules.

${ }^{2}$ U.S. Department of Energy, "Tank Waste Inventory Network System, Best Basis Estimate," Fluor Hanford Corp., 090803 (September 2003).
} 
plutonium had been removed from the top 30 centimeters of soil at the bottom of 216-Z-9 Trench using remotely controlled equipment. Plutonium concentrations of 350 nanocuries/g still exists in vadose zone sediment $127 \mathrm{ft}$ below the bottom of the trench. ${ }^{1}$

A another issue raised in the two cited publications is that 0.7 metric tons of plutonium is present in Hanford Site subsurface as "prior to 1970 buried TRU waste. ${ }^{2}$ Further according to the Government Accountability Office, "DOE has long considered pre-1970s buried wastes permanently disposed."3

This report provides a systematic review of the state-of-knowledge of plutonium and americium geochemistry at the Hanford Site. The objective of the report is to integrate existing knowledge of the subsurface migration behavior of plutonium and americium at the Hanford Site with available information in the scientific literature regarding the geochemistry of plutonium and americium in systems that are environmentally relevant to the Hanford Site. Subsequently, key research needs are identified with the ultimate goal of guiding science-based research to quantitatively assess risk at Hanford sites contaminated with plutonium and americium. This information is organized into the following chapters.

- Chapter 2.0 summarizes available information on plutonium and americium containing waste streams. Roughly $180 \mathrm{kgs}$ of plutonium-239 was discharged to 22 waste sites at Hanford.

Knowledge of the process chemistry of these waste streams is important to the understanding of how plutonium and americium moved in the subsurface. Key attributes of waste streams include high/low salt, acidic/basic, and aqueous/organic.

- Chapter 3.0 summarizes insights into plutonium and americium distribution and mobility gained from past characterization of plutonium discharge sites. The 216-B-5 reverse well provides a 60+-year "case study" in plutonium mobility in Hanford groundwater because of the direct injection of plutonium-bearing waste into groundwater from 1945-1947. Roughly $90 \%$ of the plutonium discharge to Hanford soil occurred at sites within the 200-PW-1/3/6. Past field and laboratory studies of these sites is important to examining how varying waste stream chemistries affected the distribution and mobility of plutonium and americium. Finally, historic site-wide groundwater monitoring provides the most direct insight into plutonium's mobility at Hanford due to the very long history of site operations, some extreme disposal practices and the very long history of groundwater monitoring.

- Chapter 4.0 summarizes information on the speciation and solubility of plutonium and americium in the environment. Actinide geochemistry is extremely complex and plutonium, for example, can exist in as many as four oxidation states simultaneously. Because mobilization of fixed contaminants (either precipitated within solid phases or adsorbed to mineral surfaces) to an aqueous phase is often the most likely route for human exposure and environmental impacts, developing a good understanding of speciation and its impact on plutonium and americium transport is imperative for assessing the potential risk of contaminant exposure.

\footnotetext{
${ }^{1}$ SL Charboneau, A Hopkins, CS Sutter, and JA Teal, "Decommissioning the 216-Z-9 Crib Plutonium Mining Facility at the Plutonium Finishing Plant: Issues Characterization,” Fluor Hanford Co., HNF-304575-FP, Rev.0, (2007).

${ }^{2}$ WO Greenhalgh, "Pre-1970Transuranic Solid Waste at Hanford," Westinghouse Hanford Company, WHC-SD-WM-ES-325 (1995).

${ }^{3}$ United States Government Accountability Office, Report to the Subcommittee on Energy and Water Development, Committee on Appropriations, House of Representatives, "Nuclear Waste, Plans for Addressing Most Buried Transuranic Wastes Are Not Final, and Preliminary Cost Estimates Will Likely Increase," GAO-07-761 (June 2007), available at http://www.gao.gov/new.items/d07761.pdf.
} 
- Chapter 5.0 summarizes information on adsorption and surface complexation of plutonium and americium. When metal concentrations are calculated to be below the solubility limits of solubility controlling phases, adsorption is viewed as the primary mechanism controlling solution concentrations and migration in the subsurface. Typically, adsorption to mineral surfaces will immobilize metals from the aqueous phase; however, adsorption to surface sites on mobile colloidal particles can potentially act as a transport vector under certain circumstances. This section focuses on adsorption to immobile mineral surfaces.

- Chapter 6.0 discusses the role of colloids in the potential environmental transport of plutonium and americium. For strongly sorbing and /or highly insoluble radionuclides subsurface transport could still occur in association with colloids - nanoparticles and macromolecules in the size range between $1 \mathrm{~nm}$ to $1 \mu \mathrm{m}$.

- Chapter 7.0 presents the unresolved issues related to subsurface transport of plutonium and americium at key Hanford waste sites. A set of research challenges is defined to guide subsequent research efforts. Resolution of these issues will help to improve the conceptual models and quantitative assessment of plutonium and americium migration for a broad range of Hanford Site disposal conditions. 


\subsection{Inventory and Character of Plutonium/Americium Containing Wastes}

Spent fuel was reprocessed at the Hanford Site from 1944 through 1989 for production of plutonium for nuclear weapons (Gephart 2010). Over the lifetime of the Hanford facilities, 96,900 metric tons of uranium in the form of spent fuel was reprocessed to recover 67.4 metric tons of plutonium $\left(4.2 \times 10^{6} \mathrm{Ci}\right)$ (Gephart 2010). Most of this (54.5 tons) was weapons grade metal (94\% or greater plutonium-239) produced at the PFP in the 200 West Area. The remainder (12.9 tons) was fuel grade plutonium (82\%-94\% plutonium-239).

After plutonium (product) removal, $3.37 \times 10^{4} \mathrm{Ci}$ of plutonium-239, $8.11 \times 10^{3} \mathrm{Ci}$ of plutonium-240, $1.27 \times 10^{5} \mathrm{Ci}$ of plutonium-241, and $8.27 \times 10^{4} \mathrm{Ci}$ of americium-241 remained in waste streams (Corbin et al. 2005; Watrous et al. 2002). Most of this (65\%) was disposed to single- and double-shelled tanks. The remainder was intentionally disposed to the near-surface environment at the Hanford Site. It is estimated that $11,800 \mathrm{Ci}(189 \mathrm{~kg})$ of plutonium-239; 2,900 Ci $(12.6 \mathrm{~kg})$ of plutonium-240; 37,500 Ci $(0.34 \mathrm{~kg})$ of plutonium-241; 28,700 $\mathrm{Ci}(9.0 \mathrm{~kg})$ americium-241; and $55 \mathrm{Ci}(78 \mathrm{~kg})$ neptunium-237 were disposed across the Hanford Site (Cantrell 2009). These wastes were primarily liquid process wastes disposed to constructed waste disposal facilities such as trenches, cribs, and ponds.

Cantrell (2009) presented a review of inventories of transuranic radionuclide contamination in sediments and groundwater at the Hanford Site. This review focused primarily on plutonium-239/240 and americium-241; however, other transuranic nuclides were discussed as well, including neptunium-237, plutonium-238, and plutonium-241. The scope of this review included liquid process wastes intentionally disposed to constructed waste disposal facilities such as trenches, cribs, and ponds, as well as unplanned releases to the ground surface. This review did not include liquid wastes sent to the single-shelled and double-shelled storage tanks or solid wastes disposed to Hanford Site solid waste burial grounds.

The vast majority of transuranic contaminants disposed to the vadose zone on the Hanford Site (10,200 Ci [86\%] of plutonium-239; 27,900 Ci [97\%] of americium-241; and 41.8 Ci [78\%] of neptunium-237) were disposed in sites within the PFP closure zone. This closure zone is located within the 200 West Area. Other operable units with notably high quantities of transuranic contaminant disposal include the T Farm zone with $408 \mathrm{Ci}$ (3.5\%) plutonium-239, the Plutonium Uranium Extraction zone with $330 \mathrm{Ci}(2.8 \%)$ plutonium-239, 200-W Ponds zone with $324 \mathrm{Ci}(2.8 \%)$ plutonium-239, B Farm zone with $183 \mathrm{Ci}(1.6 \%)$ plutonium-239, and the Reduction-Oxidation zone with $164 \mathrm{Ci}$ (1.4\%) plutonium-239.

Individual waste sites with estimated plutonium-239 inventories in excess of $25 \mathrm{Ci}$ are identified in Table 2.1. Also included in the table are plutonium-240, plutonium-241, and americium-241. All quantities of radionuclides presented here were decay-corrected to January 1, 2001 (Corbin et al. 2005). However, it does not appear that production of daughter products was taken into account. Plutonium-241 is of particular interest because it has a 14-year half-life and decays to americium-241 and is, therefore, a major additional source of americium-241 that has not been accounted for in Corbin et al. (2005) or Table 2.1. The 21 inactive waste sites in Table 2.1 account for $97 \%$ of the total plutonium-239 inventory estimated to have been released to the vadose zone on the Hanford Site. 
Table 2.1. Hanford Waste Sites with Estimated Plutonium-239 Inventories in Excess of $25 \mathrm{Ci}$, Decayed to January 1, 2001 (from Corbin et al. 2005)

\begin{tabular}{cccccc}
\hline Closure Zone & Waste Site & Ci Pu-239 & Ci Pu-240 & Ci Pu-241 & Ci Am-241 \\
\hline 200-E Ponds & $216-A-25$ & 29.1 & 8.53 & 155 & 2.84 \\
200-W Ponds & $216-$-U 10 & 308 & 91.9 & 1378 & 160 \\
B Farm & $216-\mathrm{B}-8$ & 126 & 9.74 & 12.7 & 1.12 \\
B Plant & $216-\mathrm{B}-5$ & 37.2 & 2.51 & 2.41 & 0.12 \\
PFP & $216-Z-1 \& 2$ & 147 & 36.7 & 521 & 188 \\
PFP & $216-Z-12$ & 2,480 & 672 & 8,910 & 8,510 \\
PFP & $216-Z-18$ & 1,770 & 532 & 8,012 & 755 \\
PFP & $216-Z-1 \mathrm{~A}$ & 3,190 & 956 & 14,400 & 3,890 \\
PFP & $216-Z-3$ & 121 & 14.1 & 39.6 & 5,230 \\
PFP & $216-Z-5$ & 29.6 & 2.00 & 1.93 & 1,180 \\
PFP & $216-Z-7$ & 505 & 40.0 & 172 & 7,350 \\
PFP & $216-Z-9$ & 1,880 & 302 & 1,060 & 565 \\
PUREX Zone & $216-\mathrm{A}-10$ & 56.4 & 13.4 & 138 & 75.3 \\
PUREX Zone & $216-\mathrm{A}-30$ & 30.7 & 10.7 & 202 & $<0.00$ \\
PUREX Zone & $216-A-5$ & 32.6 & 6.55 & 28.8 & 43.0 \\
PUREX Zone & $216-A-9$ & 183 & 64.3 & 1,210 & 0.10 \\
REDOX Zone & $216-\mathrm{S}-1 \& 2$ & 72.8 & 14.1 & 49.2 & 25.5 \\
REDOX Zone & $216-\mathrm{S}-7$ & 69.4 & 14.3 & 68.9 & 16.8 \\
T Farm Zone & $216-\mathrm{T}-26$ & 36.9 & 2.50 & 3.22 & 1.09 \\
T Farm Zone & $216-\mathrm{T}-28$ & 36.8 & 12.4 & 225 & 15.5 \\
T Farm Zone & $216-\mathrm{T}-7$ & 236 & 26.4 & 53.1 & 6.57 \\
\hline Total & & $\mathbf{1 1 , 3 7 8}$ & $\mathbf{2 , 8 3 2}$ & $\mathbf{3 6 , 6 4 3}$ & $\mathbf{2 8 , 0 1 6}$ \\
\hline
\end{tabular}

Table 2.2 includes additional data regarding the waste types that were disposed in each of the waste sites with estimated plutonium-239 inventories in excess of $25 \mathrm{Ci}$, as well as the years in which the sites operated and the volumes of waste disposed. For sites that received exceptionally high volumes (216-A-25 and 216-U-10), the wastes were generally dominated by lightly contaminated process waste or process cooling water. The wastes at sites with the highest inventories of plutonium-239 and americium-241(216-Z-12, 216-Z-18, 216-Z-1A, and 216-Z-9) consisted primarily of plutonium and americium recovery wastes from PFP. Wastes disposed in 216-Z-12 were low-salt aqueous wastes that were neutral to slightly basic (DOE/RL 2007). The wastes disposed in 216-Z-18, 216-Z-1A, and 216-Z-9 contained both aqueous and organic waste streams. The aqueous waste streams disposed to $216-Z-18$ were both high in salts and acidic (pH 1 to 2.5) (DOE/RL 2007). Wastes disposed to the 216-Z-1A Tile Field include 1.0 ML of slightly basic, aqueous waste disposed from 1949 to 1959, and 5.2 ML of highsalt, acidic waste containing significant inventories of carbon tetrachloride, disposed from 1964 to 1969 (DOE/RL 2007). The aqueous waste streams disposed to 216-Z-9 were also high salt and acid (DOE/RL 2007). 
Table 2.2. Operating Years, Volumes Disposed, and Waste Types for Waste Sites with Estimated Plutonium-239 Inventories in Excess of 25 Ci, Decayed to January 1, 2001 (Corbin et al. 2005)

\begin{tabular}{|c|c|c|c|c|}
\hline Waste Site & $\begin{array}{l}\text { Operating } \\
\text { Years }\end{array}$ & $\begin{array}{l}\text { Site Volume } \\
\quad(\mathrm{ML})\end{array}$ & Waste Type & Waste Types and Volumes Disposed \\
\hline $216-\mathrm{A}-25$ & $1958-1985$ & $2.94 \times 10^{5}$ & $\begin{array}{l}\text { Low salt, } \\
\text { near neutral }\end{array}$ & $\begin{array}{l}\text { Gable Mountain Pond received almost } \\
294,000 \text { ML of non-contact or lightly } \\
\text { contaminated process waste over its } \\
\text { operating lifetime (e.g., PUREX and B Plant } \\
\text { process cooling water; Powerhouse water), } \\
\text { with an excursion of high-level waste. }\end{array}$ \\
\hline 216-U-10 & 1944-1995 & $1.60 \times 10^{5}$ & $\begin{array}{l}\text { Low salt, } \\
\text { near neutral }\end{array}$ & $\begin{array}{l}\text { This site received } \sim 160,000 \text { ML of PUREX, } \\
\text { REDOX, and Z Plant process condensates, } \\
\text { cooling water, laundry waste, Powerhouse } \\
\text { water, and chemical sewer. }\end{array}$ \\
\hline $216-B-5$ & 1945-1947 & 32.1 & $\begin{array}{l}\text { Low salt, } \\
\text { near neutral }\end{array}$ & $\begin{array}{l}\text { This site received a total of } 32 \mathrm{ML} \text { of } 224 \\
\text { and } 5-6 \text { waste from the bismuth phosphate } \\
\text { process. }\end{array}$ \\
\hline $216-B-8$ & $1948-1953$ & 35.3 & & $\begin{array}{l}\text { This site received } \sim 35 \mathrm{ML} \text { of } 224 \text { and 5-6 } \\
\text { waste. }\end{array}$ \\
\hline $216-Z-1 \& 2$ & $\begin{array}{l}1949-1952 ; \\
1966-1969\end{array}$ & 33.7 & $\begin{array}{l}\text { High salt, } \\
\text { acidic, organic }\end{array}$ & $\begin{array}{l}\text { This site received } \sim 34 \mathrm{ML} \text { of plutonium } \\
\text { recovery, americium recovery, and } \\
\mathrm{Z} \text { Complex laboratory waste during its } \\
\text { operating lifetime. }\end{array}$ \\
\hline $216-Z-12$ & $1959-1973$ & 272 & $\begin{array}{l}\text { Low salt, } \\
\text { near neutral }\end{array}$ & $\begin{array}{l}\text { This site received about } 272 \mathrm{ML} \text { of } \\
\text { plutonium purification, } 232-\mathrm{Z} \text { incinerator, } \\
\text { and } \mathrm{Z} \text { Complex laboratory waste. }\end{array}$ \\
\hline 216-Z-18 & $1969-1973$ & 3.86 & $\begin{array}{l}\text { High salt, } \\
\text { acidic, organic }\end{array}$ & $\begin{array}{l}\text { This site received about } 4 \mathrm{ML} \text { of plutonium } \\
\text { purification and americium recovery waste. }\end{array}$ \\
\hline $216-Z-1 A$ & $\begin{array}{l}1949-1959 ; \\
1964-1969\end{array}$ & 6.21 & $\begin{array}{l}\text { High salt, } \\
\text { acidic, organic }\end{array}$ & $\begin{array}{l}\text { This site received over } 6 \mathrm{ML} \text { of plutonium } \\
\text { and americium recovery waste, and } \\
\mathrm{Z} \text { Complex chemical sewer. This site also } \\
\text { includes inventories from separately reported } \\
\text { sites (Z-1AA, Z-1AB, and Z-1AC) } \\
\text { consolidated with the } 216-\mathrm{Z}-1 \mathrm{~A} \text {. Both } \\
\text { aqueous and organic waste streams were } \\
\text { disposed to this site. }\end{array}$ \\
\hline 216-Z-3 & $1952-1959$ & 178 & $\begin{array}{l}\text { Low salt, } \\
\text { near neutral }\end{array}$ & $\begin{array}{l}\text { This site received approximately } 180 \mathrm{ML} \text { of } \\
\text { Z Complex laboratory waste and } 234-5 \mathrm{Z} \\
\text { waste. }\end{array}$ \\
\hline $216-Z-5$ & 1945-1947 & 31.0 & High salt & $\begin{array}{l}\text { This site received } 31 \mathrm{ML} \text { of } \mathrm{Z} \text { Complex } \\
\text { laboratory waste and plutonium recovery } \\
\text { waste. }\end{array}$ \\
\hline 216-Z-7 & $\begin{array}{l}1947-1957 ; \\
1965-1966\end{array}$ & 79.9 & High salt & $\begin{array}{l}\text { This site received } 80 \mathrm{ML} \text { of } \mathrm{Z} \text { Complex } \\
\text { laboratory waste, plutonium recovery waste } \\
\text { and decontamination waste. }\end{array}$ \\
\hline 216-Z-9 & 1955-1962 & 4.09 & $\begin{array}{l}\text { High salt, } \\
\text { acidic, organic }\end{array}$ & $\begin{array}{l}\text { This site received over } 4 \mathrm{ML} \text { of plutonium } \\
\text { recovery waste. Both aqueous and organic } \\
\text { waste streams were disposed to this site. }\end{array}$ \\
\hline 216-A-10 & $\begin{array}{c}1956 \\
1961-1988\end{array}$ & 3,160 & $\begin{array}{l}\text { Low salt, } \\
\text { near neutral }\end{array}$ & $\begin{array}{l}\text { This site received } \sim 3,160 \mathrm{ML} \text { of PUREX } \\
\text { process condensate/cooling water. }\end{array}$ \\
\hline
\end{tabular}


Table 2.2. (contd)

\begin{tabular}{|c|c|c|c|c|}
\hline Waste Site & $\begin{array}{l}\text { Operating } \\
\text { Years }\end{array}$ & $\begin{array}{l}\text { Site Volume } \\
\quad(M L)\end{array}$ & Waste Type & Waste Types and Volumes Disposed \\
\hline $216-\mathrm{A}-30$ & $1961-1991$ & 7,640 & $\begin{array}{l}\text { Low salt, } \\
\text { near neutral }\end{array}$ & $\begin{array}{l}\text { This site received approximately } 7635 \mathrm{ML} \text { of } \\
\text { PUREX condensate and misc. drainage. The } \\
\text { waste streams selected to represent the } \\
\text { process history of this site are } \\
\text { decontamination waste, PUREX chemical } \\
\text { sewer, PUREX steam condensate, and } \\
\text { PUREX stack drainage. }\end{array}$ \\
\hline $216-A-5$ & $\begin{array}{l}\text { 1955-1961; } \\
1966\end{array}$ & 1,630 & $\begin{array}{l}\text { Low salt, } \\
\text { near neutral }\end{array}$ & $\begin{array}{l}\text { This site received } \sim 1630 \mathrm{ML} \text { of PUREX } \\
\text { process condensate. }\end{array}$ \\
\hline 216-A-9 & $\begin{array}{l}1956-1958 \\
1966-1967\end{array}$ & 981 & $\begin{array}{l}\text { Low salt, } \\
\text { near neutral }\end{array}$ & $\begin{array}{l}\text { This site received } 980 \text { ML of PUREX } \\
\text { chemical sewer, cooling water, tank farm } \\
\text { condensate, and N Reactor decontamination } \\
\text { waste. }\end{array}$ \\
\hline $216-S-1 \& 2$ & $1952-1956$ & 160 & $\begin{array}{l}\text { Low salt, } \\
\text { near neutral }\end{array}$ & $\begin{array}{l}\text { This site received } 160 \mathrm{ML} \text { of REDOX D-1 } \\
\text { cell drainage and D- } 2 \text { process condensate. }\end{array}$ \\
\hline 216-S-7 & $1956-1965$ & 390 & $\begin{array}{l}\text { Low salt, } \\
\text { near neutral }\end{array}$ & $\begin{array}{l}\text { This site received } 390 \mathrm{ML} \text { of REDOX D-1 } \\
\text { cell drainage and D-2 process condensate. }\end{array}$ \\
\hline $216-T-26$ & $1955-1956$ & 11.1 & $\begin{array}{l}\text { Low salt, } \\
\text { near neutral }\end{array}$ & $\begin{array}{l}\text { This site received } 11 \mathrm{ML} \text { of ferrocyanide } \\
\text { waste. }\end{array}$ \\
\hline $216-\mathrm{T}-28$ & $1960-1966$ & 42.3 & $\begin{array}{l}\text { Low salt, } \\
\text { near neutral }\end{array}$ & $\begin{array}{l}\text { This site received } 42 \mathrm{ML} \text { of decontamination } \\
\text { waste and } 300 \text { Area laboratory waste. The } \\
300 \text { Area laboratory waste is represented as } \\
\text { 222-S Laboratory waste with a small } \\
\text { contribution of PL1. }\end{array}$ \\
\hline $216-\mathrm{T}-7$ & $1947-1955$ & 107 & $\begin{array}{l}\text { Low salt, } \\
\text { near neutral }\end{array}$ & $\begin{array}{l}\text { This site received } \sim 107 \mathrm{ML} \text { of } 2 \mathrm{C}, 224 \text { and } \\
5-6 \text { waste. }\end{array}$ \\
\hline
\end{tabular}




\subsection{Insights Acquired from Field and Laboratory Studies of Hanford Plutonium/Americium Waste Sites}

Previous characterization studies reviewed by Cantrell (2009) are generally focused on a few selected sites and are limited in scope. The most prevalent characterization methods used consisted of geophysical logging. Characterization of a number of sites included laboratory analysis of borehole sediment samples specifically for radionuclides and other contaminants, as well as for geologic and hydrologic properties. In some instances, more detailed research-level studies were conducted. These sites are reviewed in more detail in the following sections.

\subsection{Direct Injection of Plutonium Bearing Waste into Groundwater through 216-B-5 Reverse Well}

From 1945 to 1947, 32 ML of plutonium-bearing waste consisting of 224 and 5-6 waste from the bismuth phosphate process conducted in the plutonium recovery plant (B Plant) was disposed to the 216-B-5 disposal system (DOE/RL 1996). These alkaline low-salt liquid wastes were generated from cell washings collected in the 5-6 W cell located in the 221-B Building and from the 224-B Building and contained an estimated total of $4.3 \mathrm{~kg}$ (268 Ci) plutonium (Smith 1980). The 216-B-5 disposal system consisted of the 241-B-361 Settling Tank and a 20-cm diameter well. The well penetrated approximately $3.7 \mathrm{~m}$ below the water table, and waste was introduced into the aquifer at this level. Prior to injection, the waste was pumped into the settling tank where solids settled. Liquid waste that overflowed from the settling tank was then injected directly into the groundwater through the 216-B-5 Reverse Well. Analyses of sludge samples from the settling tank, including an in situ neutron activation study, suggested that approximately half of the plutonium inventory in the waste that was discharged to the system remained in the settling tank (Smith 1980). Estimates from the Soil Inventory Model (SIM) model (Table 2.1, Corbin et al. 2005) suggest that significantly less than half the plutonium inventory was actually injected into the 216-B-5 Reverse Well (37 Ci).

Eleven wells were drilled adjacent to the reverse well from 1947 to 1948 to characterize groundwater contamination from this discharge. Results are summarized in Brown and Ruppert (1950). In 1976, plutonium was measured in groundwater from three wells located near the 216-B-5 Reverse Well using a large-volume sampling technique (Weimer 1978). The wells sampled were 299-E28-1, 299-E28-5, and 299-E28-7 located approximately $180 \mathrm{~m}(590 \mathrm{ft}), 290 \mathrm{~m}(951 \mathrm{ft})$, and $20 \mathrm{~m}(66 \mathrm{ft})$, respectively, from the 216-B-5 Reverse Well. The sample collected from Well 299-E28-7 contained the highest concentration of plutonium-239/240 (0.16 pCi/L). Wells 299-E28-1 and 299-E28-5 had considerably lower concentrations at $0.0005 \mathrm{pCi} / \mathrm{L}$ and $0.0008 \mathrm{pCi} / \mathrm{L}$, respectively.

Additional characterization of plutonium contamination associated with the 216-B-5 Well occurred in 1979 (Smith 1980) and again in 1994 (DOE/RL 1996). As part of the characterization study of Smith (1980), three wells were drilled to basalt (299-E28-23, 299-E28-24, and 299-E28-25) and another well in the vicinity of the 216-B-5 Reverse Well was deepened to basalt (299-E28-7). Figure 3.1 shows the estimated distribution of plutonium resulting from that characterization effort. Analytical results from borehole sediments collected from the wells indicated that plutonium-239/240 concentrations greater than

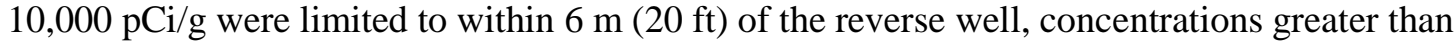
$100,000 \mathrm{pCi} / \mathrm{g}$ were limited to a narrow (1-m [3.3-ft]) layer located near the 1948 water table. The 
sample with the highest reported plutonium-239/240 concentration $(191,000 \mathrm{pCi} / \mathrm{g})$ was from

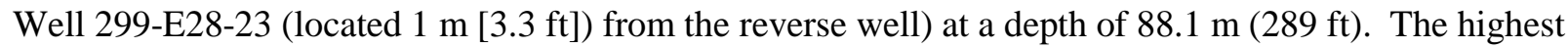

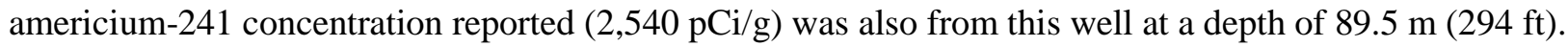

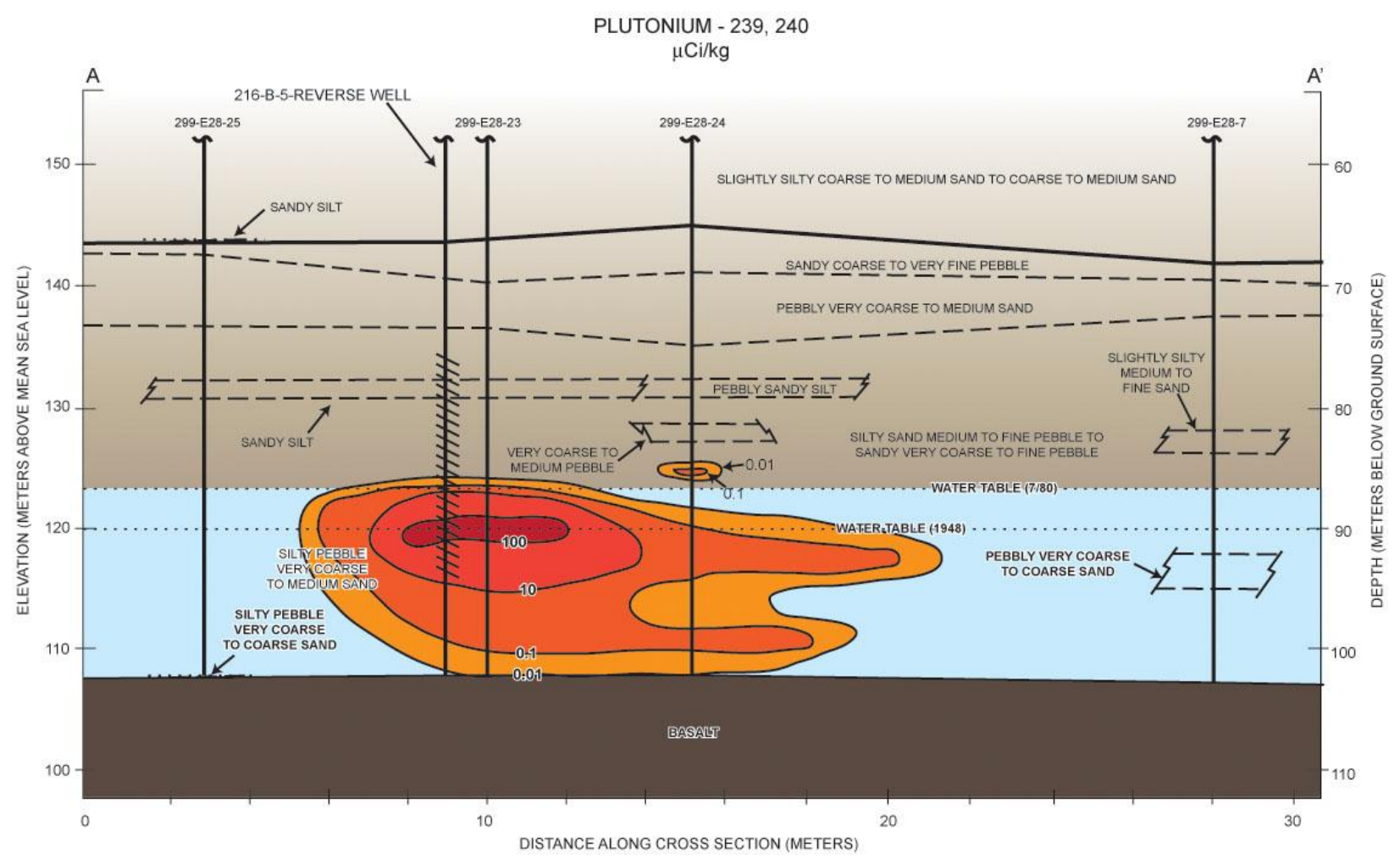

Figure 3.1. Cross-Section of Plutonium-239/240 Distribution in the Vicinity of the 216-B-5 Reverse Well (contours are in $\mu \mathrm{Ci} / \mathrm{kg}$ ) (Source: DOE/RL (1996), Figure F-4)

Figure 3.2 shows the results of sediment analyses for plutonium-239/240 and americium-241 for samples collected from Well 299-E28-23 in the depth interval where significantly elevated concentrations were found (Smith 1980). It is remarkable how similar the americium-241 depth profile is to that of plutonium-239/240. Because the geochemical behavior of $\mathrm{Am}^{3+}$ is significantly different than that of $\mathrm{Pu}^{4+}$ (see Sections 5 and 6), this similarity might not be expected. However, because americium-241 is the decay product of plutonium-241 ( $\left.\mathrm{t}_{1 / 2}=14.3 \mathrm{y}\right)$ and the wastes disposed to the 216-B-5 Reverse Well were injected only a relatively short time after the spent fuel was removed from the reactor and processed, it is likely that the majority of americium-241 in the sediments around the 216-B-5 Reverse Well was actually injected as plutonium-241.

This was confirmed by conducting a mass balance of plutonium-241, plutonium-239/240, and americium-241, as a function of time. This was done by starting with the quantities of plutonium-241 and plutonium-239/240 estimated to have been injected into the 216-B-5 Injection Well from the SIM (Corbin et al. 2005; Cantrell 2009). These values are decay corrected to January 1, 2001. The total quantity of plutonium-241 injected into the 216-B-5 Injection Well was estimated by correcting this value for decay back to 1946. This quantity of plutonium-241 was then used to determine the quantity of americium-241 that would have resulted from decay of plutonium-241 during 1946 to 1979 (when the sediment samples from Well 299-E28-23 were collected and analyzed). With this approach, the ratio of curies of 
americium-241/plutonium-239/240 in the waste injected into the 216-B-5 Reverse Well was estimated to be 0.022 (in 1979). For comparison, the average americium-241/plutonium-239/240 ratio was calculated from measurements of americium-241 and plutonium-239/240 in sediment samples collected from Well 299-E28-23 in the depth interval of $86.6 \mathrm{~m}$ to $94.5 \mathrm{~m}$ bgs (Smith 1980). The result was $0.019 \pm$ 0.007 , which confirms that the majority of americium-241 in the sediments around the 216-B-5 Reverse Well originated from in situ decay of plutonium-241 that was injected along with plutonium-239/240.

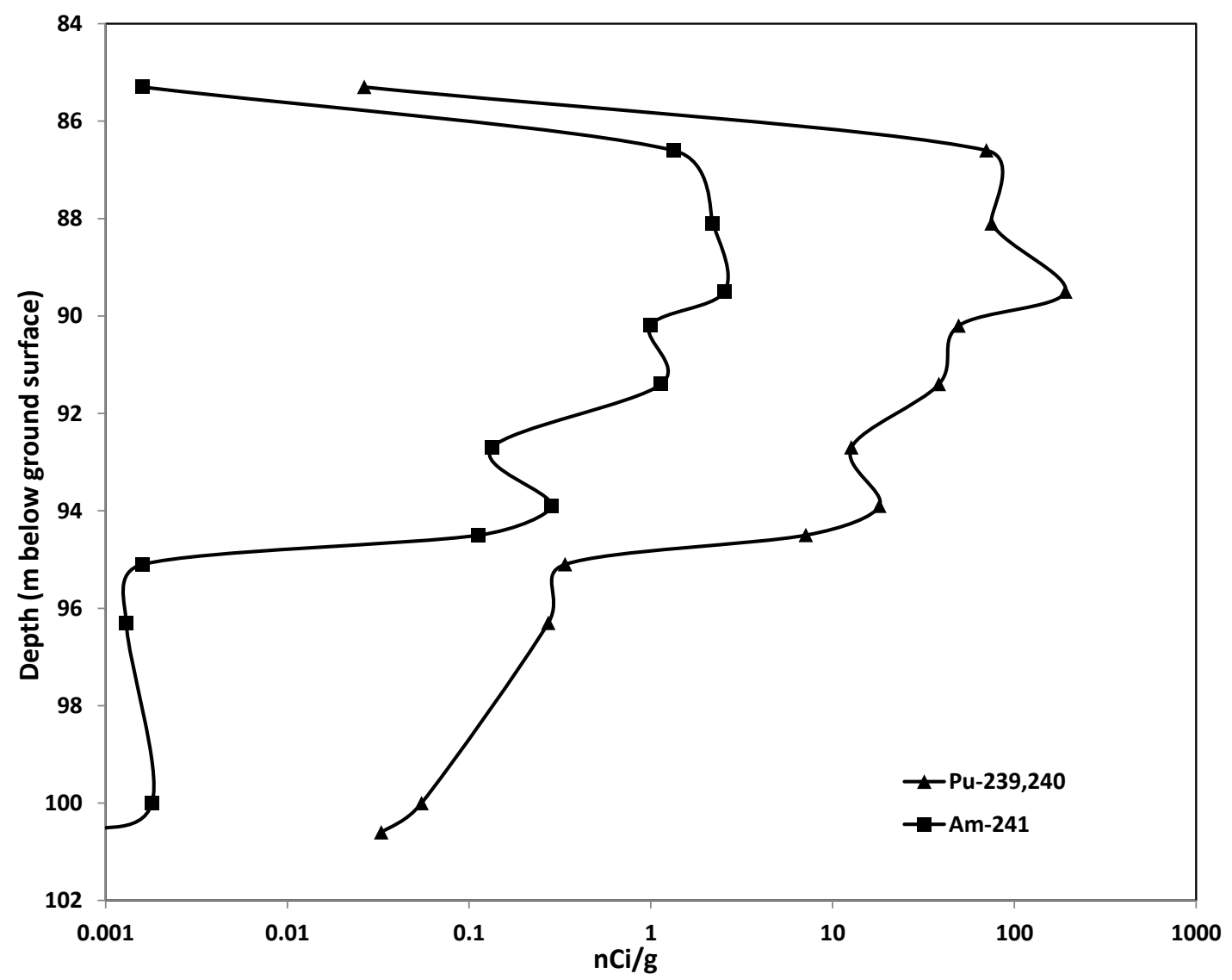

Figure 3.2. Plutonium-239/240 and Americium-241 in Sediment Collected from Well 299-E28-23 (Smith 1979)

In 1995, DOE implemented a treatability test plan for the 216-B-5 Reverse Well for key groundwater contaminants that included cesium-137, strontium-90, and plutonium-239/240 (DOE/RL 1996). Testing and modeling were performed to determine whether groundwater extraction was a viable remediation alternative. Plutonium concentrations in extracted groundwater are shown in Figure 3.3. The concentration of plutonium-239/240 in the extracted groundwater quickly dropped to values between 15 and $25 \mathrm{pCi} / \mathrm{L}$. Assuming that the Corbin et al. (2005) inventory estimate of $37 \mathrm{Ci}$ is accurate and that the removal efficiency remains as observed it would require extraction of between 1.5 and 2.5 trillion gallons of water to remove the source. At the groundwater pump rate of $\sim 30 \mathrm{gpm}$ (114 liters per minute), it would take between 25,000 to 40,000 years to remove the plutonium-239/240 present in the aquifer proximal to the 216-B-5 Reverse Well. The conclusion of the treatability test regarding the 216-B-5 Reverse Well (DOE/RL 1996, p. 7-3) was that the B-5 Reverse Well plume were not a risk to 
offsite groundwater and recommended that the plume be removed from the accelerated interim remedial measure pathway and that groundwater monitoring in the vicinity continue.

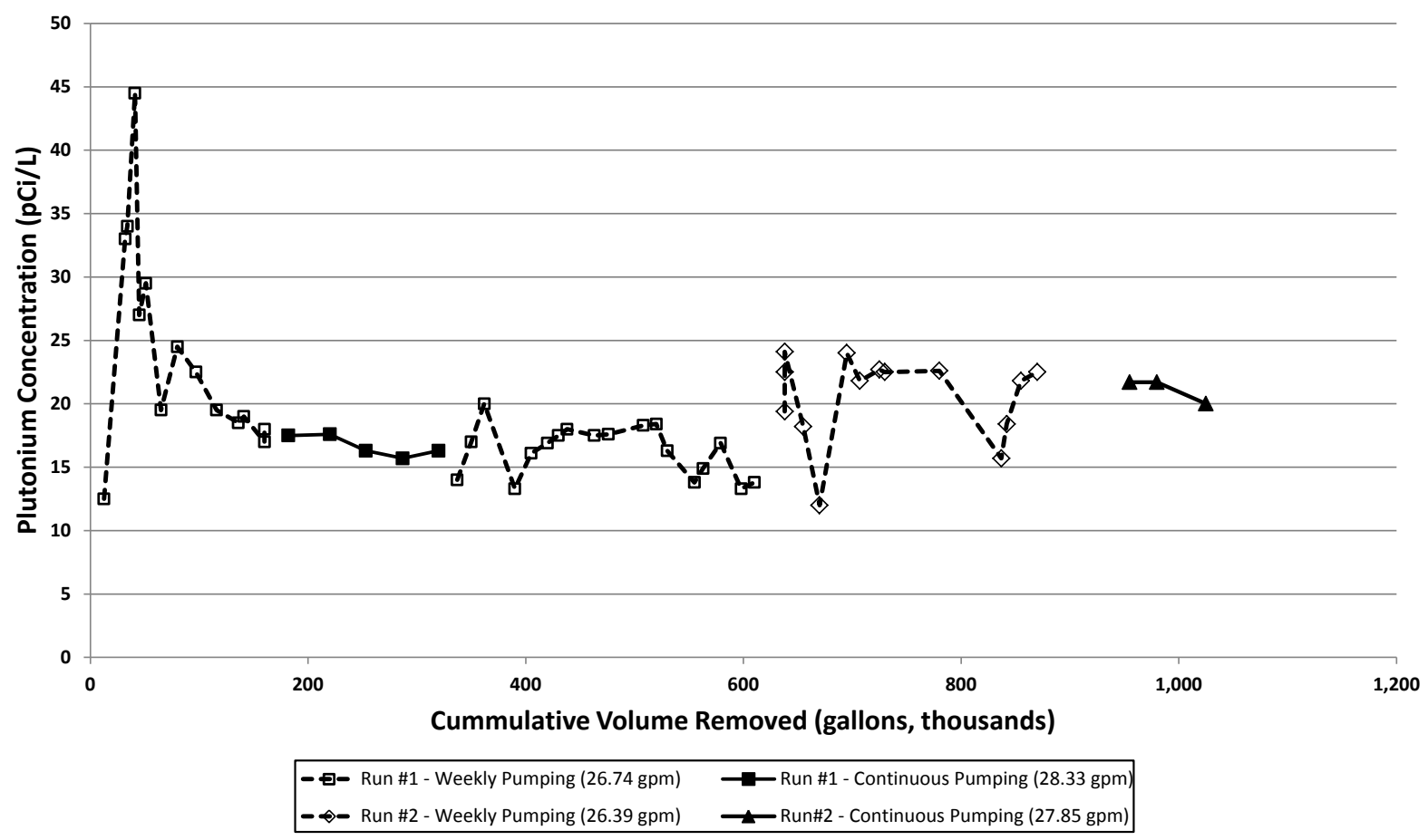

Figure 3.3. Plutonium 239/240 Extracted from 216-B-5 Reverse Well During Treatability Testing (Source: DOE/RL (1996), Figure 4-4)

\subsection{Plutonium and Americium at the 200-PW-1/3/6 Operable Units}

The Plutonium/Organic-Rich Group Operable Unit (OU) waste sites are in the 200 East and 200 West Areas near the center of the Hanford Site. The Plutonium/Organic-Rich Group OU includes three OUs where liquid wastes were disposed into cribs, French drains, trenches, an injection/reverse well, settling tanks, drain/tile fields, and at an unplanned release site. The three OUs are the 200-PW-1 OU, the 200-PW-3 OU, and the 200-PW-6 OU. The 200 PW-1 OU waste sites primarily received plutonium and organic-rich wastes (mostly carbon tetrachloride, TBP, and lard oil) from processes within the Z Plant Complex (now referred to as the PFP complex). The 200-PW-3 OU waste sites received organic-rich wastes (primarily refined kerosene [normal paraffin hydrocarbon], TBP, and butanol) from the A Plant (PUREX process). The 200-PW-6 OU waste sites received plutonium-rich wastes from the PFP complex but did not receive organic-rich wastes from that complex. Both the 200-PW-1 and 200-PW-6 OU waste sites are in the 200 West Area. The 200 PW-3 OU waste sites are in the 200 East Area.

From analyses of the various waste sites within the 200-PW-1/3/6 OUs, it was concluded that sites can be classified into two major categories based primarily upon the type of wastes that were received by each site (Cantrell and Riley 2008). These two waste categories are low-salt near-neutral waste and acidic high-salt waste with organic complexing agents (Cantrell et al. 2003). 
The 216-Z-9 Trench is an example of a waste site that received acidic high-salt waste with organic complexing agents. Remedial investigations conducted for the 216-Z-9 Trench have shown that significant plutonium and americium have moved to depths of up to $120 \mathrm{ft} \mathrm{bgs}$. To better understand the reasons for this observed migration of plutonium, Cantrell and Riley (2008) conducted a review of the subsurface behavior of plutonium and americium at the Hanford Site 200-PW-1/3/6 OUs. A summary of what is known regarding the history, characterization work performed, and current distribution of contaminants at the 216-Z-9 Trench is provided below.

\subsubsection{Background and History of Plutonium and Americium Contamination at the 216-Z-9 Trench}

The 216-Z-9 Trench is located in the 200 West Area and consists of a $6 \mathrm{~m}(20 \mathrm{ft})$ deep excavation with a $37-\mathrm{m}$ by $27-\mathrm{m}(120-\mathrm{ft}$ by $90-\mathrm{ft})$ concrete cover. The walls of the trench slope inward to form an $18-\mathrm{m}$ by $9-\mathrm{m}$ (60-ft by $30-\mathrm{ft})$ floorspace, which has a slight slope to the south. The underside of the concrete cover was paved with acid-resistant brick/tiles. The concrete cover of the trench is supported by six concrete columns. A map of 216-Z-9 Trench and vicinity including characterizations wells 299-W15-46 and 299-W15-48 are shown in Figure 3.4.

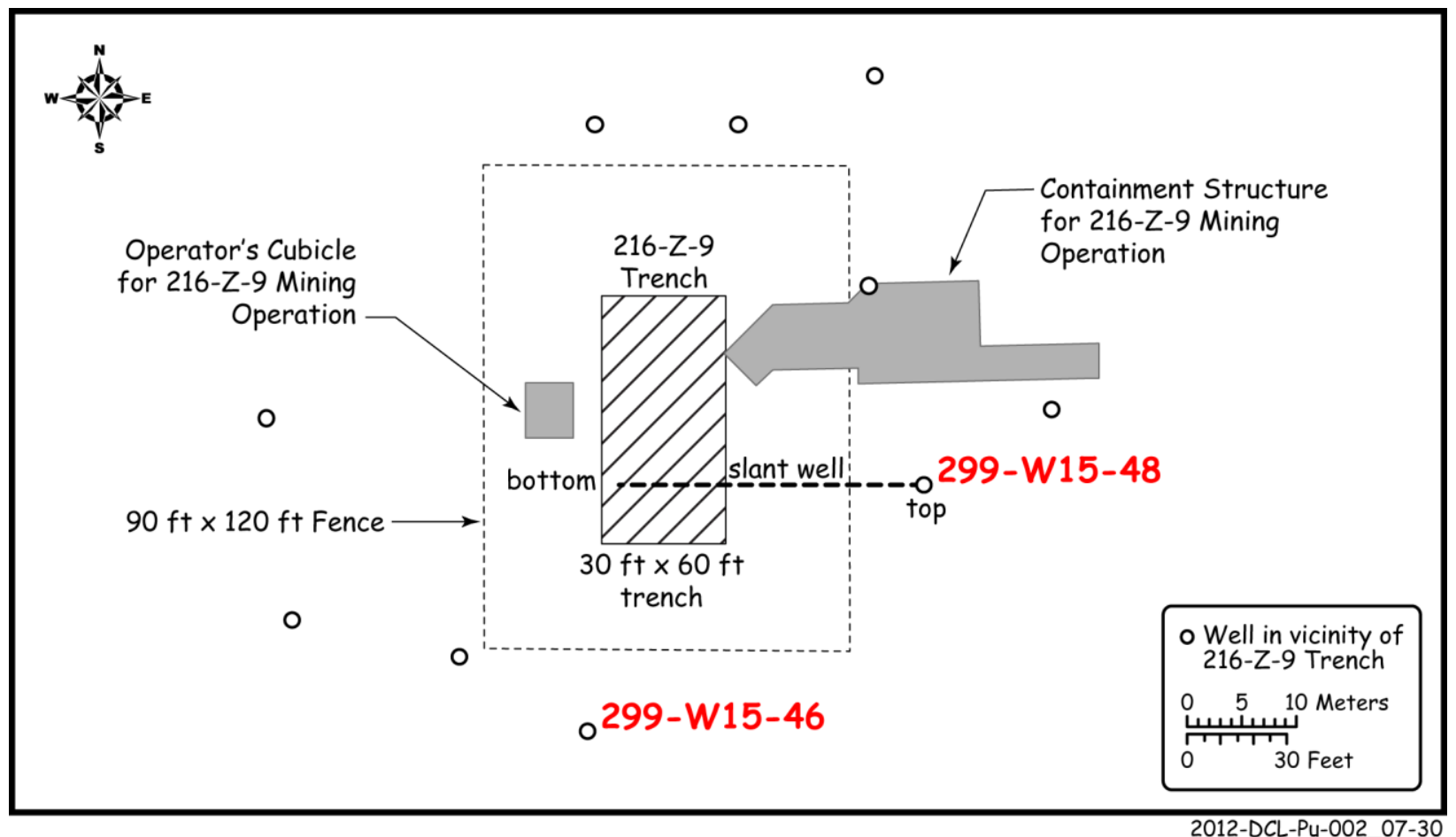

Figure 3.4. Map of 216-Z-9 Trench and Vicinity Including Wells 299-W15-46 and 299-W15-48

The trench was used from 1955 to 1962 for disposal of Z Plant RECUPLEX aqueous and organic liquid waste (DOE/RL 2007). Over 4 ML of liquid wastes were disposed (Corbin et al. 2005). The estimated inventories of plutonium-239/240, plutonium-241, and americium-241 are 2,180 Ci, 1,060 Ci and $565 \mathrm{Ci}$, respectively (all decay corrected to 1/01/2001, Table 2.1). The two major liquid streams used in the RECUPLEX process were an aqueous stream composed of nitric and hydrofluoric acids to produce soluble plutonium as plutonium nitrate and an organic phase solvent extraction stream composed of 
carbon tetrachloride and TBP (85:15 ratio) or carbon tetrachloride and dibutybutyl phosphonate (DBBP; 50:50 ratio) to recover the plutonium or plutonium and americium from the aqueous streams. The process was used to recover plutonium from many different types of scrap or wastes, such as ingot and casing skulls (ingoting dross), slag, and crucible button line supernates. With exposure to ionizing radiation and nitric acid, the TBP in the solvent extraction stream gradually would degrade to dibutyl phosphate (DBP). DBP has a much greater affinity for plutonium than TBP and would not work in the process because of its poor stripping properties. The degraded solvent was periodically discharged in batches and replaced with fresh solvent. The DBBP solution was discharged after each use. The RECUPLEX waste solutions consisted of aluminum, magnesium, calcium, and other metal nitrate salt wastes; used solvents (15\% TBP, i.e., a mixture of TBP and DBP) or 50\% DBBP in carbon tetrachloride; other organic wastes such as solvent washings, fabrication oil (a mixture of lard oil and carbon tetrachloride used as a cutting oil during the machining of plutonium) (Ridgway et al. 1971), and other deteriorated materials from hood and equipment flushes.

Additional details regarding the estimated inventory of materials discharged to the trench include the following: 50 to $140 \mathrm{~kg}$ plutonium (3,600 to $11,000 \mathrm{Ci}$ plutonium-239/240 [assuming $6 \%$ by weight plutonium-240, DOE/DP 1996]); 8,580 Ci of americium-241; 130,000 to $480,000 \mathrm{~kg}$ (286,600 to $1,058,219 \mathrm{lb})$ of carbon tetrachloride; 9,300 L lard oil; and 500,000 kg $(1,102,310 \mathrm{lb})$ of nitrate (DOE/RL 1992).

Characterization of the site began in the 1950s, when wells were installed around the 216-Z-9 Trench to monitor contaminant migration. Between 1954 and 1967, nine wells were drilled around the 216-Z-9 Trench. Scintillation probe profiles were completed for each boring at least once between 1963 and 1970, and at least once more between 1973 and 1976. Radiological contamination was detected in two borings (Wells 299-W15-8 and 299-W15-86) at a depth from 15.2 to $38.1 \mathrm{~m}$ (49.5 to $125 \mathrm{ft}$ ) bgs (see ARH 1977 for profiles). Later geophysical logging of Well 299-W15-8 detected plutonium-239 from 15.1 to $32.3 \mathrm{~m}$ (50 to $106 \mathrm{ft}$ ) bgs with a maximum activity of $300,000 \mathrm{pCi} / \mathrm{g}$ at $15.5 \mathrm{~m}(51 \mathrm{ft}) \mathrm{bgs}$ (WHC 1993).

Sediment samples were collected from the bottom of the trench to a maximum depth of $3 \mathrm{~m}(9 \mathrm{ft})$ below the trench floor during 1959, 1961, and 1963 and analyzed for the presence of plutonium. Concern over the potential for the accumulation of a critical mass of plutonium on the floor of the trench prompted additional sampling during 1973 (Smith 1973). Both plutonium and americium were detected at relatively high concentrations across the $3-\mathrm{m}$ depth profile. Samples from the bottom of the trench to $15 \mathrm{~cm}$ ( 6 in.) below the floor yielded plutonium-239 concentrations of up to $1.2 \times 10^{12} \mathrm{pCi} / \mathrm{L}$ (sediment), and americium-241 concentrations of up to $1.4 \times 10^{11} \mathrm{pCi} / \mathrm{L}$ (sediment) were found within $15 \mathrm{~cm}(6 \mathrm{in}$.) of the bottom of the trench. At a depth of $3 \mathrm{~m}(9 \mathrm{ft})$, plutonium-239 and americium-241 concentrations were $2.0 \times 10^{9} \mathrm{pCi} / \mathrm{L}$ (sediment) and $1.4 \times 10^{8} \mathrm{pCi} / \mathrm{L}$ (sediment), respectively. Soil $\mathrm{pH}$ was 4.1 at a depth of $2.4 \mathrm{~m}(8 \mathrm{ft})$ and generally acidic through the entire $3 \mathrm{~m}(9 \mathrm{ft})$ soil profile (Smith 1973). These sediment core samples were also examined by autoradiography and electron microprobe analysis (Price and Ames 1975). Results of these analyses were consistent with plutonium being discharged as both particulate and dissolved plutonium. The particulate plutonium had a composition consisting of greater than $70 \%$ (wt \%) $\mathrm{PuO}_{2}$. This material was shown to have been filtered out within the first meter of sediment underlying the bottom of the trench and accounted for the high concentrations of plutonium observed in this area of the sediment profile. Dissolved plutonium (disposed originally as dissolved plutonium(IV) and less than 0.5 wt $\% \mathrm{PuO}_{2}$ ) penetrated deeper within the sediment profile and was deposited in association with sediment minerals that had undergone acid induced silicate hydrolysis. 


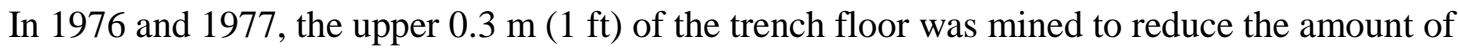
plutonium in the trench. The mining operation removed an estimated $58 \mathrm{~kg}(128 \mathrm{lb})$ of plutonium, leaving an estimated $48 \mathrm{~kg}$ (106 lb) of plutonium in the trench (RHO 1978). A discussion of results of the characterization performed during excavation can be found in DOE/RL (2007, Section 2.1.3).

Further characterization of the 216-Z-9 Trench was conducted in 1991 to 1993 to support soil-vapor extraction activities for carbon tetrachloride. A dense nonaqueous phase liquid (DNAPL) investigation conducted on the northeast corner of 216-Z-9 Trench in 1995 detected no DNAPL in Well 299-W15-32 (BHI 1995). Remedial investigation activities conducted at the trench included sampling from one deep well (299-W15-46), one slant well (299-W15-48), and a phased carbon tetrachloride investigation. DNAPL was identified in a silt lens $20 \mathrm{~m}(66 \mathrm{ft}) \mathrm{bgs}$ south of the trench. Further characterization results relevant to plutonium and americium determined from samples collected from Wells 299-W15-46 and 299-W15-48 are provided in Section 3.2.2. Soil-vapor extraction has been ongoing at the 216-Z-9 Trench since 1993 to remove carbon tetrachloride from the vadose zone.

The quantity of waste disposed to the 216-Z-9 Trench was calculated to be sufficient to fill approximately 1.5 times the vadose zone pore space beneath the floor of the trench; however, it appears that downward migration of the plutonium and americium was interrupted at the Cold Creek Unit (approximately 120 feet bgs) and is being held in place here and higher in the vadose zone (see Section 3.2.2). In the 200-ZP-1 Groundwater OU (where the 216-Z-9 Crib is located), plutonium has been detected in groundwater samples only twice. The concentrations of plutonium and americium detected in unfiltered groundwater samples from Well 299-W15-8 were $8.3 \mathrm{pCi} / \mathrm{L}$ plutonium-239/240, and $0.14 \mathrm{pCi} / \mathrm{L}$ americium-241 (May 7, 1990), and $1.9 \mathrm{pCi} / \mathrm{L}$ plutonium-239/240, and $5.9 \mathrm{pCi} / \mathrm{L}$ americium-241 (November 13, 1991). After this, the groundwater table declined below the elevation of the bottom of the well and the well went dry.

\subsubsection{Soil Analysis Results from Wells 299-W15-46 and 299-W15-48}

In 2004-2006, Well 299-W15-46 (Borehole C3426) and Well 299-W15-48 (Borehole C3427) were drilled to better characterize the extent of contamination originating from 216-Z-9 Trench. Well 299-W15-48 was drilled as a slant borehole starting approximately $63 \mathrm{ft}$ east of the 216-Z-9 Trench at a $32^{\circ}$ angle from vertical and extending below the Trench. Figure 3.4 shows the locations of these wells relative to the 216-Z-9 Trench. Geophysical logging using the Spectral Gamma Logging System was performed during these drilling activities. The geophysical log data reports are included in Appendix E of WMP (2005) and Appendix D of WMP (2007). Soil samples collected during the drilling of Wells 299-W15-46 and 299-W15-48 at the 216-Z-9 Trench were analyzed for a variety of contaminants. Results of the analyses are tabulated in Appendix B of the remedial investigation report (DOE/RL 2007). Results for plutonium, americium, TBP, pH, and nitrate are discussed below (Cantrell and Riley 2008; Felmy et al. 2010).

Maximum concentration results for plutonium, americium, neptunium, TBP, and the lowest $\mathrm{pH}$ value, along with corresponding depth intervals for sediment samples collected during the drilling of Well 299-W15-46, are presented in Table 3.1. It is notable that the highest plutonium-239/240 result is coincident with both the highest TBP result and the lowest $\mathrm{pH}$ value measured. This suggests that plutonium-239/240 may have migrated through the vadose zone relatively unimpeded along with the organic and/or acidic high-salt aqueous waste streams. 
Table 3.1. Maximum Concentration and Depth Interval for Plutonium-239/240, Americium-241, TBP, and Lowest $\mathrm{pH}$ Value and Depth Interval, Well 299-W15-46

\begin{tabular}{lccc}
\hline & \multirow{2}{*}{ Maximum } & \multicolumn{2}{c}{ Depth Interval (ft bgs) } \\
\cline { 3 - 4 } Constituent or Parameter & Concentration & Top & Bottom \\
\hline Plutonium-239/240 & $115,000 \mathrm{pCi} / \mathrm{g}$ & 63.5 & 66 \\
Americium-241 & $324,000 \mathrm{pCi} / \mathrm{g}$ & 47.5 & 50 \\
$\mathrm{TBP}$ & $2,100 \mathrm{mg} / \mathrm{kg}$ & 63.5 & 66 \\
$\mathrm{pH}$ & 3.9 & 63.5 & 66 \\
\hline
\end{tabular}

Plutonium, americium, and TBP concentration data are plotted as a function of average core depth below ground surface in Figure 3.5. The bottom of a silt layer that occurs at about $65 \mathrm{ft}$ bgs is indicated as well as the bottom of the Cold Creek unit at about $120 \mathrm{ft}$ bgs. High concentrations of plutonium, americium, and TBP occur at and above the bottom of the silt layer, indicating that plutonium and americium migrated with co-contaminants during the operational period. Because this well is located approximately $55 \mathrm{ft}$ south of the trench, it is also apparent that this upper silt layer has enabled migration of TBP, plutonium, and americium horizontally along and above this layer (i.e., the concentrations of TBP, plutonium and americium just below the silt layer are significantly lower than concentrations observed within the silt layer). The same argument would appear to hold for americium in the Cold Creek unit.

Plutonium, americium, and $\mathrm{pH}$ data as a function of average core depth below ground surface are shown in Figure 3.6. A number of low values of $\mathrm{pH}$ are indicated on this graph. A sample collected from the average core depth of $65 \mathrm{ft}$ bgs has a particularly low $\mathrm{pH}$ value of 3.9. Other low $\mathrm{pH}$ values of 6.0 and 6.6 are located at average core depths of $111 \mathrm{ft} \mathrm{bgs}$ and $49 \mathrm{ft} \mathrm{bgs,} \mathrm{respectively.} \mathrm{These} \mathrm{results} \mathrm{suggest} \mathrm{that}$ significant impacts (e.g., loss of buffering capacity of the sediment) have occurred to sediment underlying the 216-Z-9 Trench as a result of acidic high-salt aqueous waste-sediment interactions. Impacts to the silt layer and Cold Creek unit also have occurred but apparently not sufficient to prevent attenuation of plutonium and americium to occur in these layers. High concentrations of americium occur above both the silt layer and the Cold Creek unit and at locations where values of $\mathrm{pH}$ are below neutral.

Sediment nitrate data for Well 299-W15-46 and Well 299-W15-48 as a function of average core depth bgs are shown in Figure 3.7. In contrast to the behavior of TBP, plutonium, and americium, horizontal migration of nitrate occurred only at and above the Cold Creek unit and not the upper silt layer. The reason for this is not readily apparent.

Maximum concentration results for plutonium, americium, neptunium, and TBP, along with the depth interval, for soil samples collected during the drilling of Well 299-W15-48 are presented in Table 3.2. No $\mathrm{pH}$ values are available for the Well 299-W15-48 soil samples. As was the case for Well 299-W15-46, data for Well 299-W15-48 indicate that the highest concentrations of plutonium and TBP occur at the same depth, indicating that plutonium migrated with co-contaminants during the operational period. 


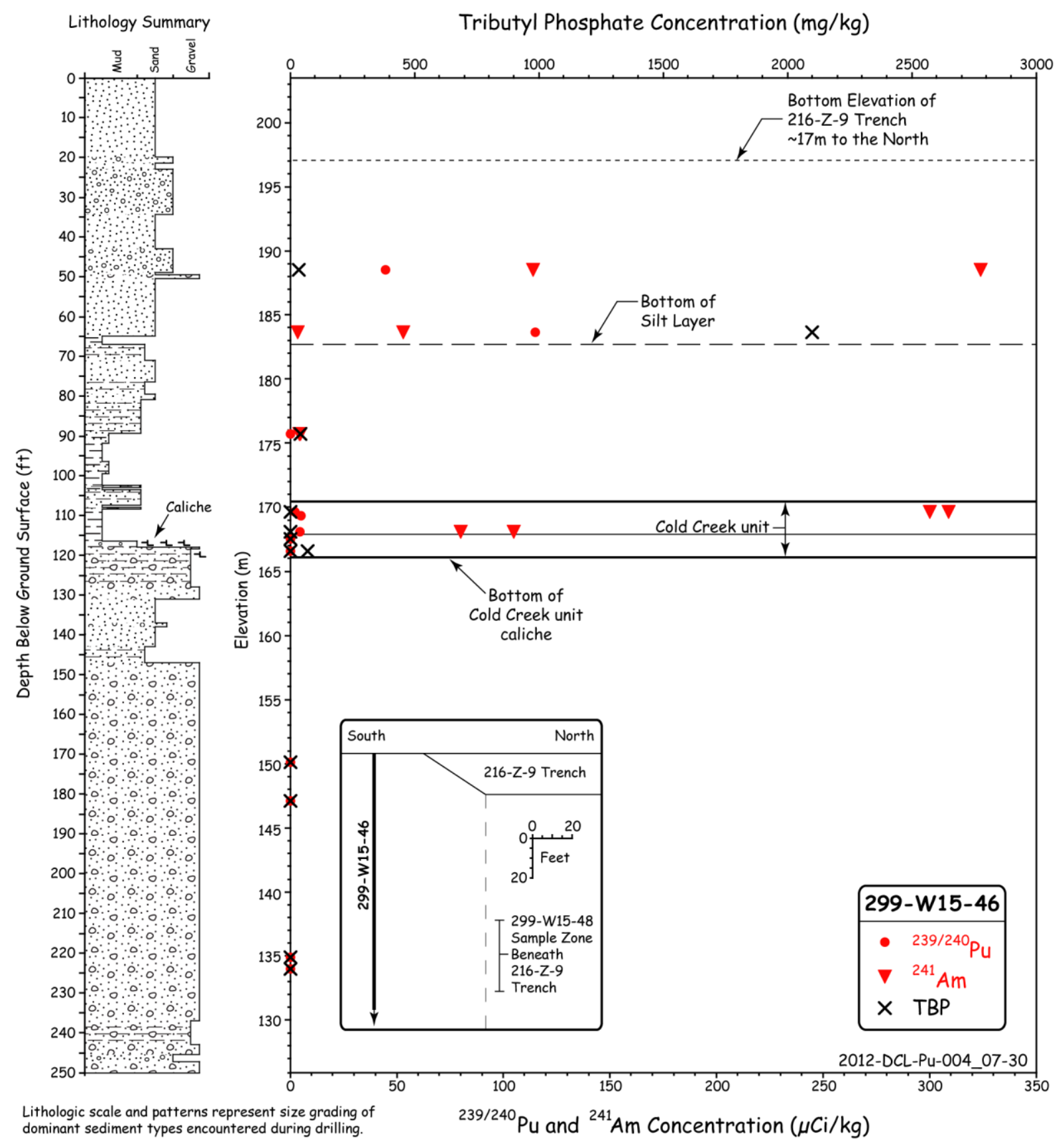

Figure 3.5. Plutonium, Americium, and TBP Concentrations as a Function of Depth Measured in Soil Samples from Well 299-W15-46 (symbols at same depth represent duplicate analyses) 


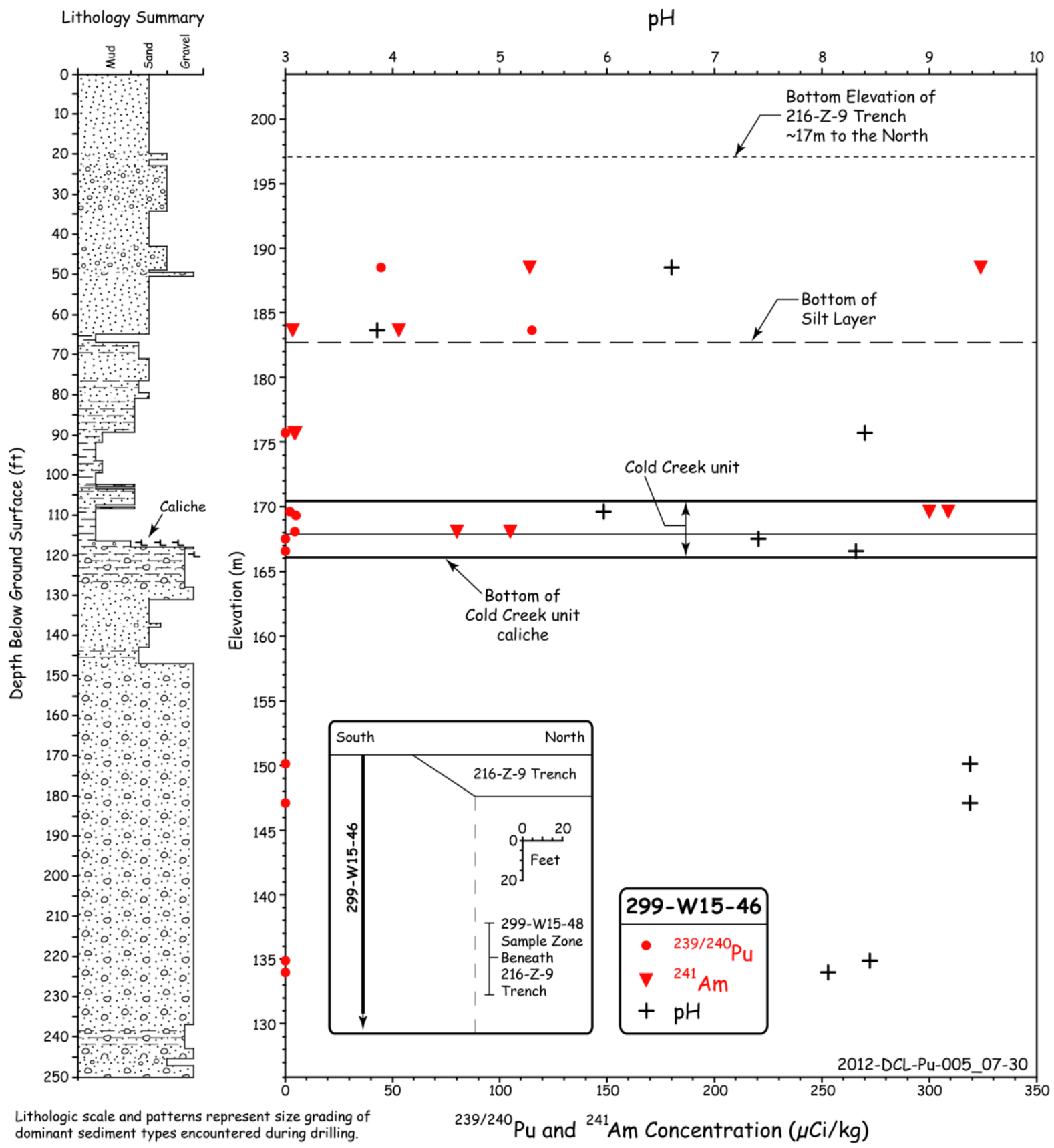

Figure 3.6. Plutonium, Americium, and $\mathrm{pH}$ as a Function of Depth Measured in Soil Samples from Well 299-W15-46 (symbols at same depth represent duplicate analyses) 


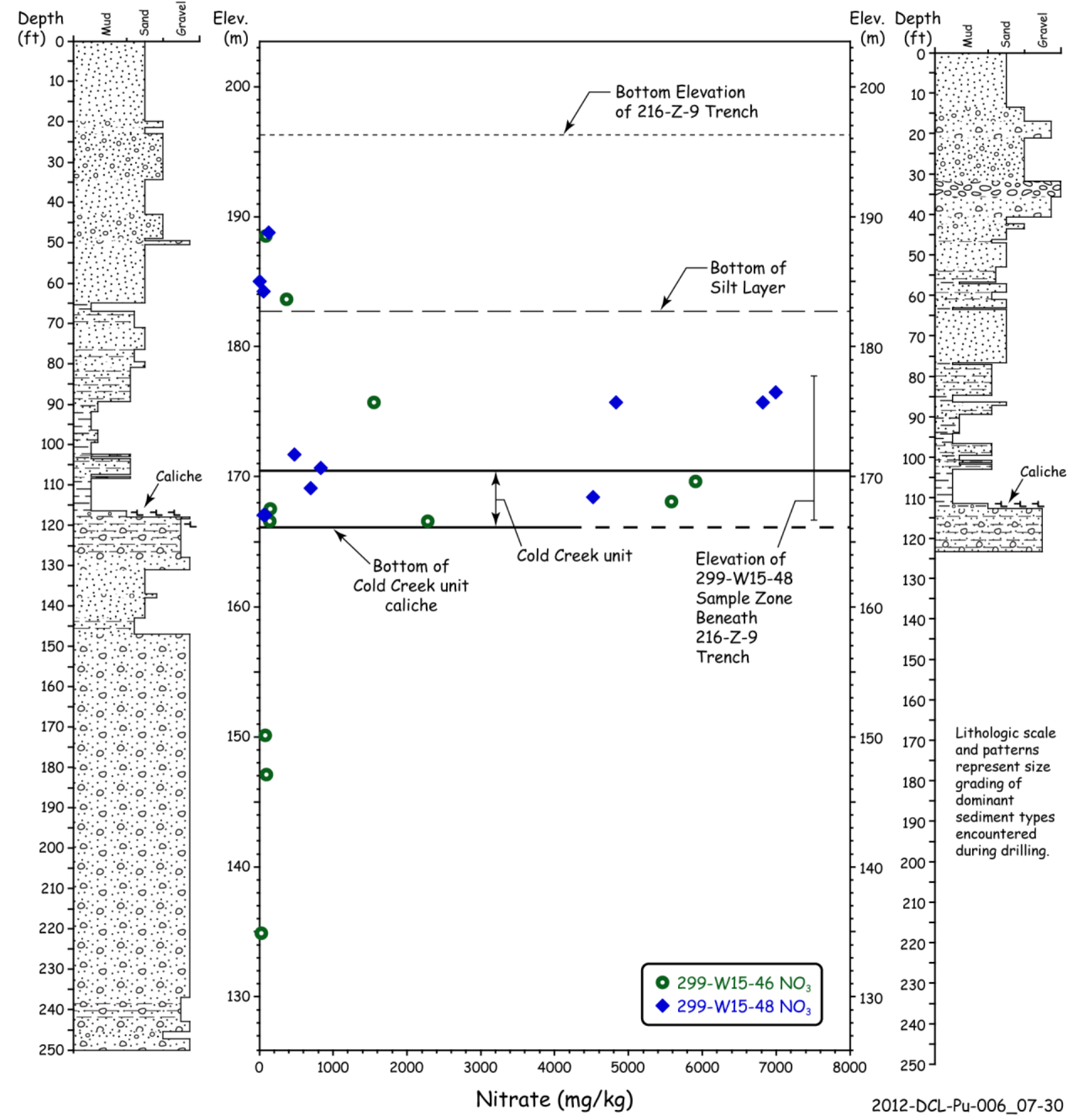

Figure 3.7. Nitrate Concentrations as a Function of Depth Measured in Soil Samples from Wells 299-W15-46 and 299-W15-48

Table 3.2. Maximum Concentration and Depth Interval for Plutonium-239/240, Americium-241, and TBP, Well 299-W15-48

\begin{tabular}{lccc}
\hline \multirow{2}{*}{$\begin{array}{c}\text { Radionuclide Contaminant } \\
\text { of Potential Concern }\end{array}$} & Maximum Concentration & Depth Interval (ft bgs) \\
\cline { 3 - 4 } Plutonium-239/240 & $254,000 \mathrm{pCi} / \mathrm{g}$ & 70 & Bottom \\
Americium-241 & $131,000 \mathrm{pCi} / \mathrm{g}$ & 118.5 & 120.5 \\
TBP & $3,000 \mathrm{mg} / \mathrm{kg}$ & 70 & 72 \\
\hline
\end{tabular}


Plutonium, americium, and TBP concentration data for Well 299-W15-48 as a function of average core depth below ground surface are shown in Figure 3.8. Note that samples collected above approximately $82 \mathrm{ft}$ bgs were located east of the 216-Z-9 footprint and samples collected below $82 \mathrm{ft}$ bgs were directly below the 216-Z-9 footprint. These data are consistent with that of Well 299-W15-46, indicating that horizontal migration of TBP, plutonium, and americium had occurred at or above the upper silt layer located above $65 \mathrm{ft}$ bgs. The acidic high-salt component of the aqueous waste stream was able to breach this layer and continue its downward migration to the Cold Creek unit, carrying with it americium and a small amount of the plutonium in the waste. Americium and a small amount of plutonium showed attenuation within and at the bottom of the Cold Creek unit. Vertical migration of plutonium and americium appears to have been stopped within the Cold Creek unit, below which plutonium and americium concentrations are low. This layer appears to have been effective at buffering the acidic waste coming into contact with this layer (see Figure 3.6) and preventing significant further downward migration of the waste below the Cold Creek unit. These results and those for Well 299-W15-48 indicate that lateral spreading of the acidic waste occurred above the silt layer and the Cold Creek unit below the 216-Z-9 Trench.

\subsubsection{Plutonium Mobility Studies on 216-Z-9 Trench Samples}

As part of a plutonium mobility study (Cantrell et al. 2008), various additional analyses were conducted on selected sediment samples collected from the two wells (299-W15-46 and 299-W15-48) drilled near the 216-Z-9 Trench. Analyses included moisture content, determination of the less than sand size fraction (silt plus clay), carbon analysis, scanning electron microscopy/energy dispersive spectroscopy analysis, microwave-assisted acid digestions for total element analysis, and extraction tests using Hanford Site groundwater as the leachate. Results of the extraction tests were used as input to conduct equilibrium geochemical modeling of the solutions using Geochemist's Workbench ${ }^{\circledR}$.

The highest concentrations of plutonium and americium were associated with sediments of low silt/clay content located above silt/clay rich layers within the sediment profile. It was also found that plutonium and americium were relatively enriched in the silt/clay portion of these samples. Scanning electron microscopy/energy dispersive spectroscopy analysis indicated the plutonium and americium in these sediments does not occur as discrete micron-size particles. More recent analyses using high resolution NanoSIMS and x-ray absorption fine structure (XAFS) are described in Section 6.1.

Leaching of these sediment samples with Hanford Site groundwater indicated release of plutonium and americium from the sediments correlates most significantly with the acidity of the water and not the initial concentrations of plutonium and americium in the sediments. Only extracts that were acidic after contact with the sediments ( $\mathrm{pH} 4.3$ to 5.4) contained detectable concentrations of extractable plutonium $\left(6.2 \times 10^{-10} \mathrm{M}\right)$ and americium $\left(6.7 \times 10^{-10}-3.5 \times 10^{-9} \mathrm{M}\right)$. Water extracts from samples containing high concentrations of TBP indicated that if the TBP degradation products DBP and monobutyl phosphate are available in these sediments, they do not significantly increase the extractability of plutonium or americium.

Geochemical modeling results indicated the plutonium and americium concentrations in water in contact with these sediments is highly undersaturated with respect to $\mathrm{PuO}_{2}(\mathrm{am})$ and $\mathrm{Am}(\mathrm{OH})_{3}(\mathrm{c})(\mathrm{Cantrell}$ et al. 2008). Sediment extracts that had measureable concentrations of plutonium and americium occurred only in samples that were fairly acidic ( $\mathrm{pH} 4.3$ to 4.6 ). 


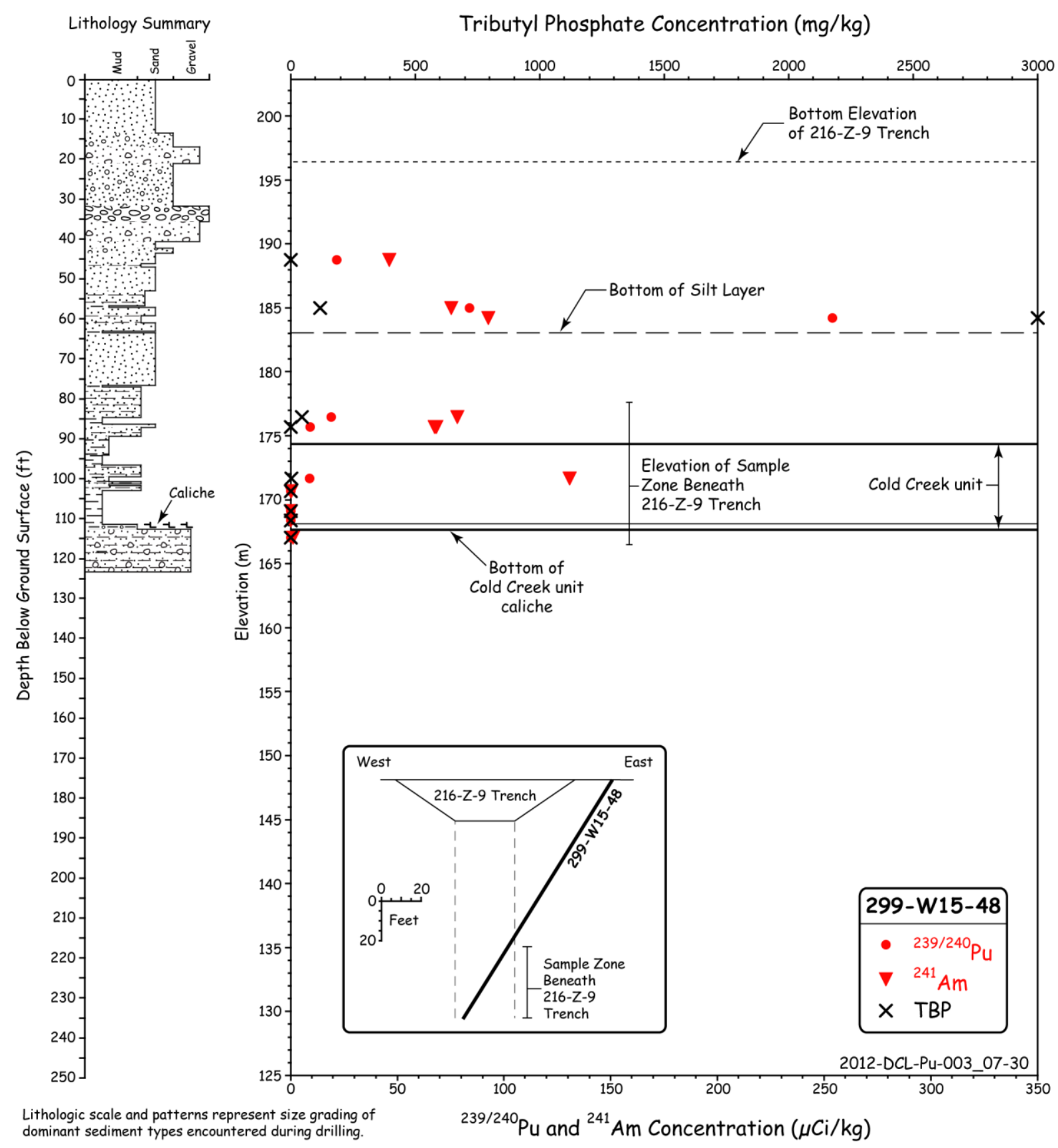

Figure 3.8. Plutonium, Americium, and TBP Concentrations as a Function of Depth Measured in Soil Samples from Well 299-W15-48 


\subsubsection{Distribution of Plutonium and Americium Below the 216-Z-1A Tile Field}

The 216-Z-1A Tile Field was constructed in 1949 and received 1 ML of overflow of liquid waste from the 216-Z1, 216-Z2, and 216-Z3 Cribs that contained only minor amounts of plutonium. Large amounts of plutonium were disposed to the 216-Z-1A Tile Field when it received 6 ML of acidic actinide bearing waste from the Plutonium Recovery Facility between 1964 and 1969. The waste was distributed to the vadose zone through buried pipe consisting of a single 100-m long central distributor pipe and fourteen 21-m long laterals in a "herringbone" pattern.

The distribution of plutonium and americium in sediments beneath the 216-Z-1A Tile Field was investigated by Price et al. (1979). In this work, 16 characterization wells were drilled within the vicinity of the 216-Z-1A Tile Field. It was determined that the highest concentrations of plutonium-239/240 and americium-241 occurred in sediments located immediately below the central distributor pipe. The maximum vertical extent of contamination was found to be approximately $30 \mathrm{~m}$ below the bottom of the tile field and approximately $30 \mathrm{~m}$ above the groundwater table. A cross section and plan view of the 216Z-1A Tile Field and graphical representations of the waste distribution are shown in Figure 3.9. Comparison of plutonium-239/240 and americium-241 concentration depth profiles from the various wells indicated that lateral spreading of the liquid waste occurred along sediment layers, but was limited to a $10 \mathrm{~m}$ wide zone around the perimeter of the tile field.

The highest concentrations of plutonium-239/240 $\left(4 \times 10^{4} \mathrm{nCi} / \mathrm{g}\right)$ and americium-241 $(2.5 \times$ $10^{3} \mathrm{nCi} / \mathrm{g}$ ) were found in sediments from Well 299-W18-149. This well was located immediately beneath the central distributor pipe near the entrance to the tile field. Figure 3.10 shows the distribution of plutonium-239/240, americium-241, and the ratio of americium-241/plutonium-239/240 in sediments collected from Well 299-W18-149 as a function of depth (Price et al. 1979). The depth distribution profiles for plutonium-239/240 and americium-241 are similar. A peak in concentration for both plutonium-239/240 and americium-241 occurs at a depth of $14.3 \mathrm{~m}$ and is associated with the top of a silt layer. Although the depth distribution profiles for plutonium-239/240 and americium-241 are similar, they are not identical. This is more readily apparent by observing the ratio of americium-241/ plutonium-239/240. This ratio is lowest in the shallower depths and increases with depth down to approximately $8 \mathrm{~m}$. A possible explanation for this behavior is that over the course of waste disposal in the 216-A-1A Tile Field, a fraction of plutonium-241 emplaced early on decays to americium-241. During subsequent disposal of acidic waste solutions, americium-241 is preferentially mobilized relative to plutonium, resulting in the observed americium-241/plutonium-239/240 depth profile.

\subsubsection{Comparison of Key Site Features of Sites Receiving Acidic High-Salt Wastes and Low-Salt Near-Neutral Wastes}

In this section, a comparison is made between two key waste site types (acidic high-salt waste and low-salt near-neutral waste) and their impact on plutonium and americium migration in the vadose zone. The 216-Z-9 Trench is one of the better characterized sites that received acidic high-salt waste with organic complexing agents. The 216-Z-12 Crib is used as an example of a site that received low-salt near-neutral wastes. 


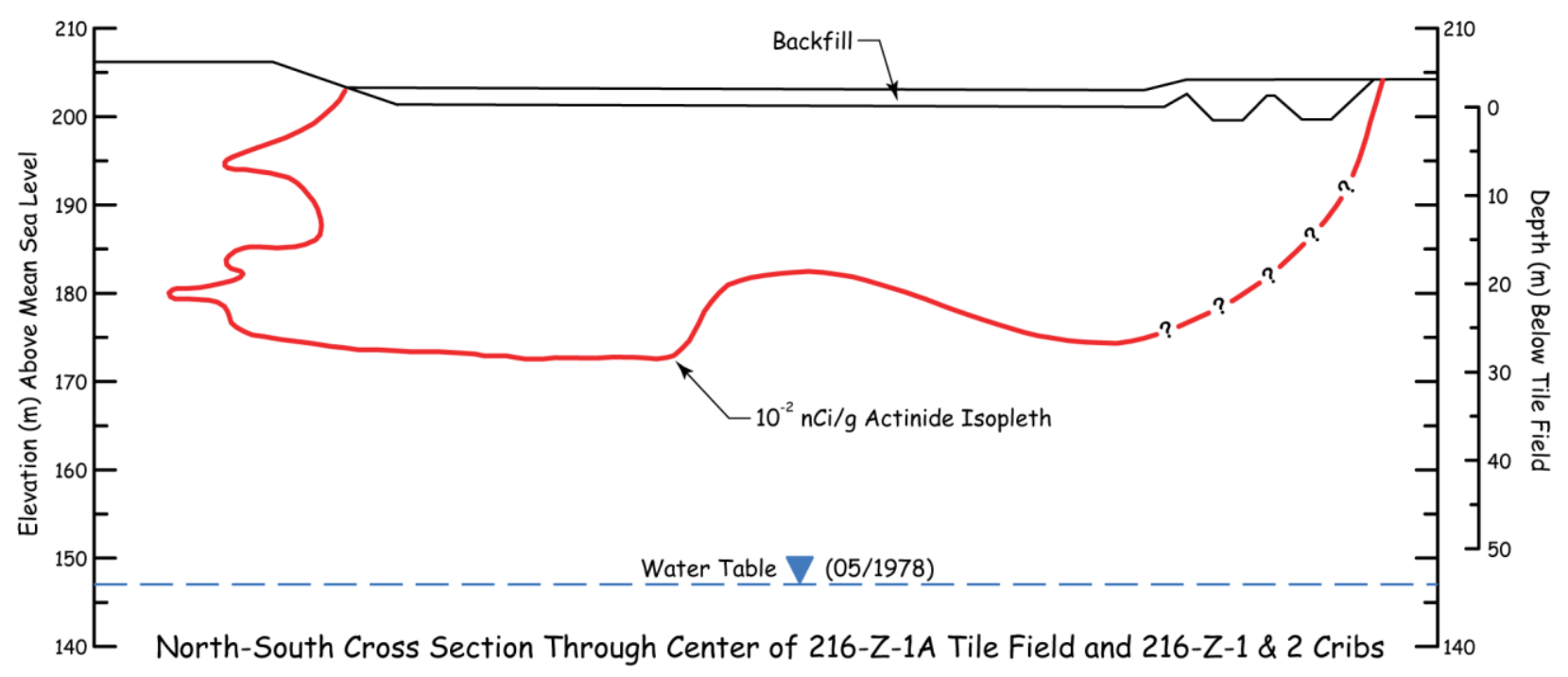

$\phi$

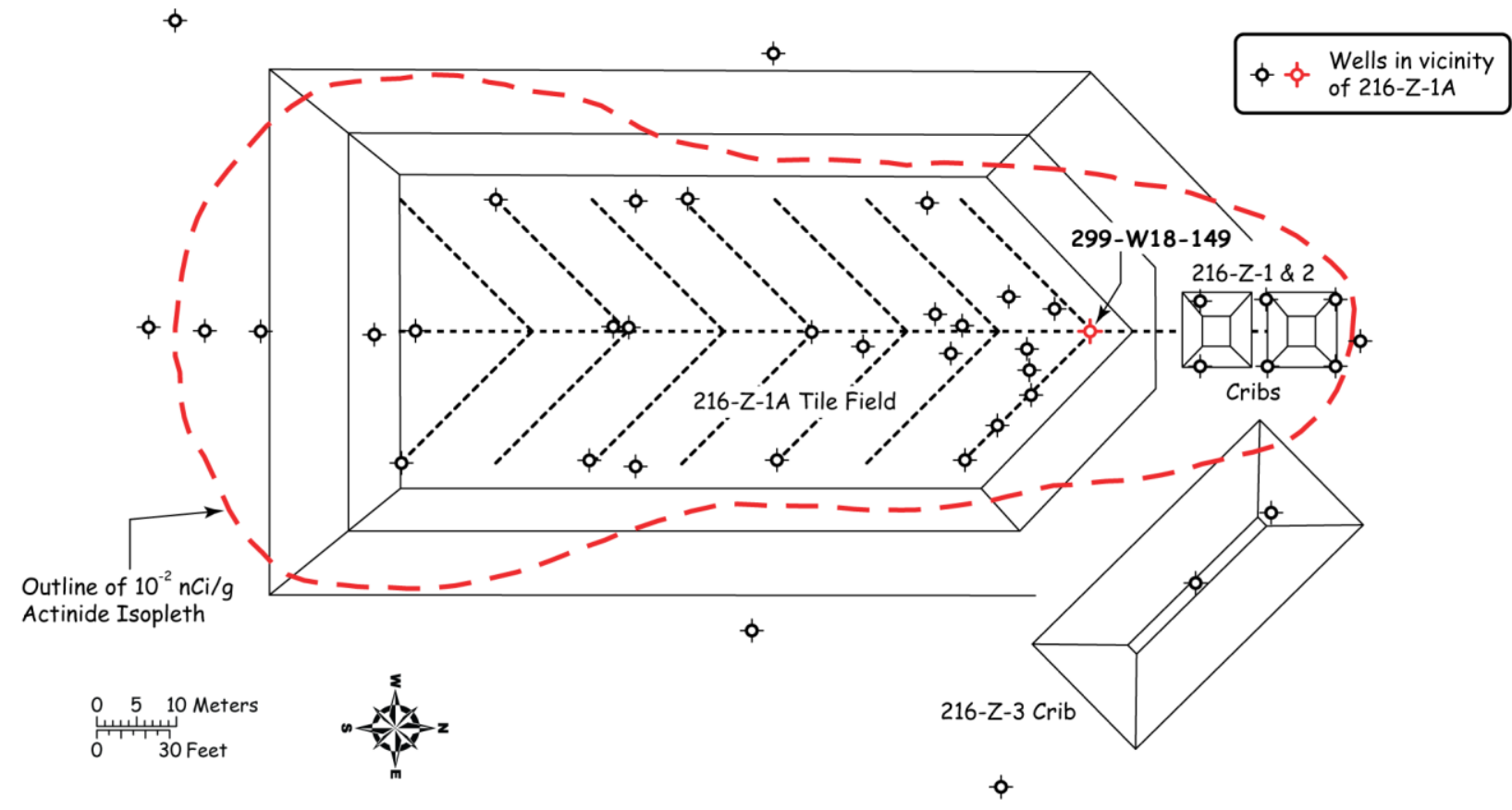

Plan View of 216-Z-1A Tile Field and 216-Z-1, -2 \& -3 Cribs

2012-DCL-Pu-001_07-30

Figure 3.9. North-South Cross Section Through the Center of the 216-Z-1A Tile Field and Distribution of Waste (top), and Plan View of 216-Z-1A Tile Field and Distribution of Waste (bottom) (dots indicate well locations) 


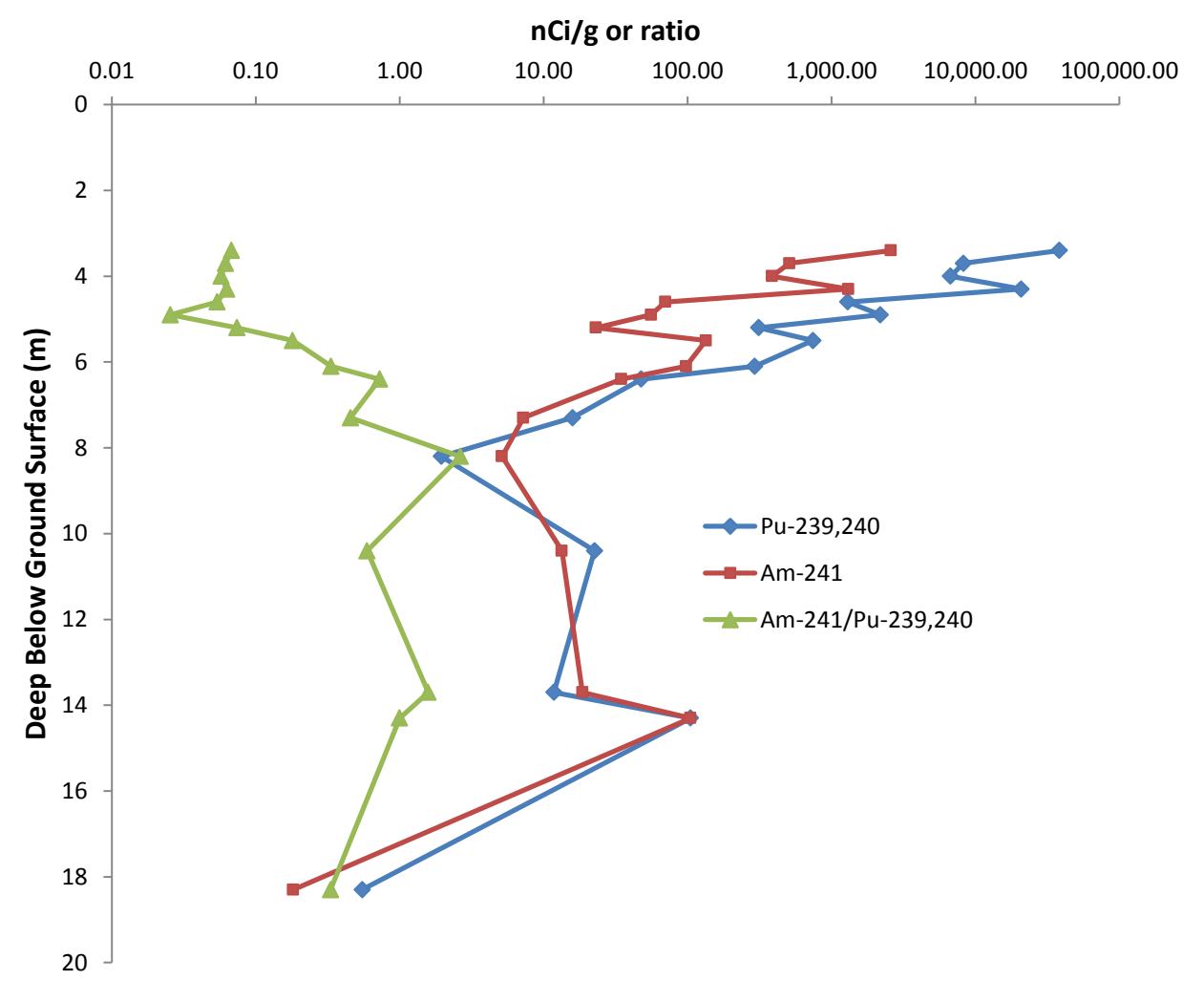

Figure 3.10. Plutonium-239/240, Americium-241 and Americium-241/Plutonium-239/240 Ratio in Sediment Collected from Well 299-W18-149 (Price et al. 1979)

Table 3.3 summarizes key features important for understanding the differences in migration behavior of plutonium and americium at these two representative sites during artificial recharge conditions (Cantrell and Riley 2008; DOE/RL 2007). Prior to disposal to the 216-Z-12 Crib, waste first passed through the Z-361 settling tank. The 216-Z-12 Crib received nearly 70 times the volume of waste (lowsalt near-neutral waste) that the 216-Z-9 Trench received. Despite this fact, relatively little migration of plutonium and americium away from the point of discharge occurred at the 216-Z-12 Crib. The maximum plutonium and americium concentrations in sediments below the 216-Z-12 Crib occurred just below the disposal point and decreased rapidly with distance from the bottom of the crib. This occurred despite the very large volumes of waste ( 281 million L) that were disposed in the trench.

The differences in depths of contaminant migration can be attributed to differences in chemical and physical properties of the wastes disposed at each of these sites. Unlike the low-salt near-neutral waste discharged at the 216-Z-12 Crib, the highly acidic waste disposed to the 216-Z-9 Trench moved down through the soil profile and, over time, consumed the buffering capacity of the underlying sediment. Loss of sediment buffering capacity allowed highly acidic subsurface conditions to prevail as waste discharge continued over a seven-year period. The high subsurface acidity and presence of organic complexants could potentially enhance plutonium and americium migration under the 216-Z-9 Trench (i.e., higher solubility in pore water and reduced sorption to sediment); however, the exact mechanism remains to be determined. 
Table 3.3. Summary of Key Waste Site Features for Two Representative Highly Impacted Waste Sites of the 200-PW-1 Operable Unit (DOE/RL 2007)

\begin{tabular}{|c|c|c|}
\hline Waste Site & 216-Z-12 Crib & 216-Z-9 Trench \\
\hline Waste category & Low-salt, alkaline & Acidic high-salt, organic/rich \\
\hline Waste volume (L) & $281,000,000$ & $4,090,000$ \\
\hline Footprint $\left(\mathrm{m}^{2}\right)$ & 546 & 162 \\
\hline Duration (years) & 14 & 7 \\
\hline Average volumetric flux rate $\left(\mathrm{L} / \mathrm{m}^{2}-\mathrm{yr}\right)$ & 36,800 & 3,610 \\
\hline $\mathrm{pH}$ of infiltrating waste & $>10$ & 2.5 \\
\hline Co-contaminants & nitrate, fluoride & $\begin{array}{c}\mathrm{CCl}_{4}, \mathrm{TBP}, \mathrm{DBBP}, \mathrm{DBP}, \mathrm{MBP}, \\
\text { lard oil, nitrate }\end{array}$ \\
\hline $\mathrm{Pu}$ - Depth of Primary Maximum & Bottom of crib (20 ft bgs) & Bottom of trench (20 ft bgs) \\
\hline $\begin{array}{l}\mathrm{Pu} \text { - Depth of Secondary Max. Conc. } \\
\text { (ft. bgs) }\end{array}$ & $120-137$ & $63.5-66$ \\
\hline $\mathrm{Pu}$ - Secondary Max. Conc. (pCi/g) & 54 & 115,000 \\
\hline
\end{tabular}

Most of the sites within the 200-PW-1/3/6 OUs received wastes that had the same general characteristics as those received by one of the two representative waste sites presented in Table 3.3. For example, the characteristics of the waste disposed to the 216-Z-1A Tile Field were similar to those disposed in the 216-Z-9 Trench. The footprint 216-Z-1A Tile Field $\left(2,370 \mathrm{~m}^{2}\right)$ is considerably larger than that of the 216-Z-9 Trench $\left(162 \mathrm{~m}^{2}\right)$, and the volumetric flux rate was about one-third that of the 216-Z-9 Trench $\left(1,310 \mathrm{~L} / \mathrm{m}^{2}-\mathrm{y}\right)$. These differences in site characteristics and waste disposal history are the primary reasons that wastes disposed to the 216-Z-1A Tile Field did not reach, saturate, and spread horizontally along the Cold Creek unit as occurred below the 216-Z-9 Trench.

The characteristics of the waste disposed to the 216-Z-18 Crib were similar to those disposed in the 216-Z-1A Tile Field; however, the footprint of the $216-\mathrm{Z}-18 \mathrm{Crib}\left(7,505 \mathrm{~m}^{2}\right)$ is considerably larger. As a result, the volumetric flux rate was relatively low $\left(133 \mathrm{~L} / \mathrm{m}^{2}-\mathrm{y}\right)$ and significant plutonium contamination below the 216-Z-18 Crib reached only relatively shallow depths (approximately $60 \mathrm{ft}$ bgs) compared to the 216-Z-9 Trench (120 ft bgs) or the 216-Z-1A Tile Field (110 ft bgs).

\subsection{Historic Site-Wide Monitoring of Plutonium in Groundwater}

Despite the fact that over 11,800 Ci of plutonium-239 bearing waste was disposed to the vadose zone at the Hanford Site, only very small amounts have been detected in groundwater. Groundwater monitoring has been a routine practice since the earliest days of Hanford Site operations and has been continually expanded and refined. The Hanford Site maintains an extensive network of groundwater monitoring wells that are routinely sampled for key contaminants of concern.

For the period of October 1, 2008-December 31, 2009, 922 monitoring wells and 326 shoreline aquifer tubes were sampled to determine the distribution and movement of contaminants (DOE/RL 2010). Many of the wells and aquifer tubes were sampled multiple times during the reporting period. A total of 18,899 samples were analyzed for the reporting period (October 1, 2008-December 31, 2009). A search of Hanford's Environmental Dashboard Application (http://environet.hanford.gov/eda/) for calendar years 2010 and 2011 showed plutonium and gross alpha sampling rates as displayed in Table 3.4. In a more 
wide ranging search of the Hanford Environmental Dashboard Application from 1984 through mid-2011 there were 52 laboratory validated detections of plutonium-239/240 in groundwater above 15 pCi/L (U.S. Environmental Protection Agency [EPA] maximum contaminant level [MCL]). All of these measurements came from three wells located within a few meters of the 216-B-5 Reverse Well. Only one other well onsite has historical measurements above 1 pCi/L (Well 299-W15-8, located in the vicinity of the 216-Z-9 Trench). This search included 722 distinct samples collected from 137 wells in the 200 West Area. Today, this extensive base of historical information provides a direct means of observing plutonium impacts on and mobility within Hanford Site groundwater.

Table 3.4. Number of Wells Sampled and Distinct Sample Results for Plutonium and Gross Alpha during 2010 and 2011

\begin{tabular}{lcc}
\hline \multicolumn{1}{c}{ Constituent } & Wells Samples & Sample Results \\
\hline Plutonium 239/240 & 92 & 240 \\
Gross Alpha & 780 & 2661 \\
\hline
\end{tabular}

Figure 3.11 shows trend plots for plutonium-239/240 concentrations for the three monitoring wells closest to the 216-B-5 Reverse Well. A handful of measurements were above $100 \mathrm{pCi} / \mathrm{L}$ in the early 1990s. More recent groundwater monitoring near the 216-B-5 Reverse Well indicates that the associated plutonium plume has not moved and concentrations in groundwater are generally in the range of 1-40 pCi/L (DOE/RL 2008). The highest reported plutonium concentration measured in fiscal year 2006 was from Well 299-E28-23, with filtered values of 12.0 and $12.7 \mathrm{pCi} / \mathrm{L}$ and unfiltered values of 35.4 and $40.4 \mathrm{pCi} / \mathrm{L}$. The lower concentrations in the filtered samples suggest that most of the plutonium is associated with filterable particulates and potentially colloids. Plutonium concentrations in Well 299E28-23 have not exhibited a clear change in trend in recent years.

The only two plutonium values detected in groundwater that were not from wells near the 216-B-5 Reverse Well were from Well 299-W15-8 in the 200-ZP-1 Groundwater OU (where the 216-Z-9 Crib is located). For this well, both detection occurrences were from Well 299-W15-8 during the 1990s (8.3 pCi/L [5/7/1990] and 1.9 pCi/L [11/13/1991]) from unfiltered samples.

In 2011 a record of decision (EPA 2011) was signed for four operable units containing plutonium waste discharge sites mostly located near PFP in the 200 West Area. Also in 2011, five groundwater wells in this area of interest were selected for routine monitoring of plutonium, americium and their isotopes. The expanded sampling from these wells will add to the base of information regarding plutonium and americium in the environment at Hanford.

\subsection{Summary and Implications of Past Studies}

The implications of past studies at the 216-B-5 Reverse Well, the 216-Z-9 Trench, 216-Z-1A Crib, and groundwater monitoring are summarized in this section. Studies of the 216-B-5 Reverse Well and the groundwater monitoring results provide some insight into plutonium and americium mobility under typical Hanford background conditions (neutral to slightly alkaline), whereas studies of the 216-Z-9 Trench and 216-Z-1A Crib provide some insight into plutonium and americium mobility under acidic high-salt organic waste disposal conditions. 


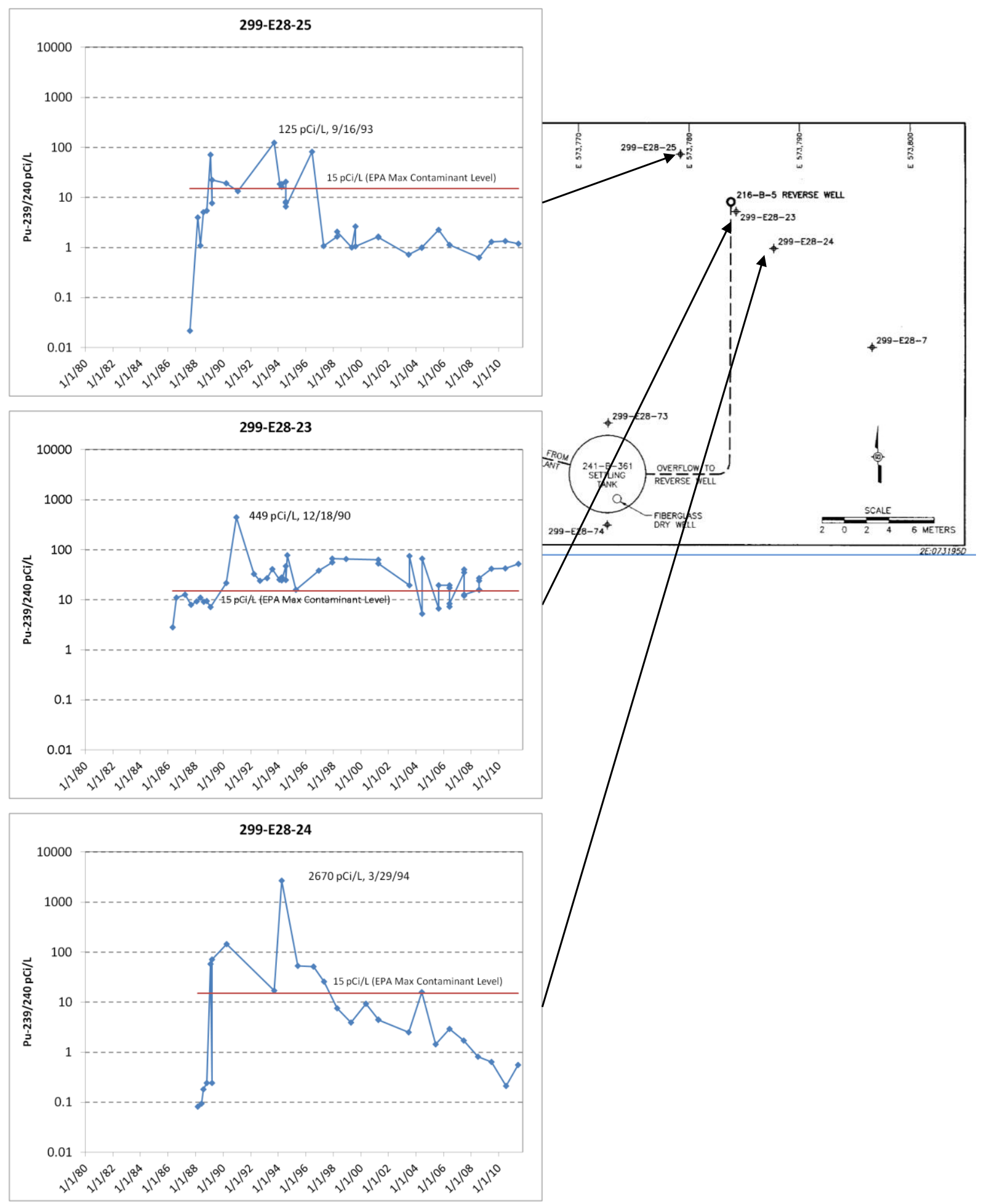

Figure 3.11. Trends in Plutonium Groundwater Concentrations near the 216-B-5 Reverse Well Injection Site, Includes Filtered and Unfiltered Samples (Source: Hanford Environmental Information System [HEIS] query, October 13, 2011)

3.19 
The 216-B-Reverse Well provides a case study of plutonium mobility in Hanford groundwater. There is probably no better location to assess the likelihood of plutonium mobility in groundwater at the Hanford Site.

From 1945 to 1947 , nearly 10 million gallons of plutonium-bearing waste (up to $4.3 \mathrm{~kg}$ of plutonium) was injected directly into the groundwater at the 216-B-5 Reverse Well. Characterization of this site in 1979 and again in 1994 shows the vast majority of plutonium remains within a few meters of the injection site. Measured ratios of americium-241/plutonium-239/240 also indicated that little if any separation of americium and plutonium has occurred over the years since disposal. Three groundwater monitoring wells within $7 \mathrm{~m}$ of the injection site routinely show plutonium detection with occasional readings slightly exceeding drinking water standards $(15 \mathrm{pCi} / \mathrm{L})$. However, continued monitoring does not show increasing concentrations of plutonium. A treatability study at this site was conducted in the mid-1990s to determine if an interim remedial action would be effective. The results of the treatability test showed that only insignificant quantities of plutonium could be removed with groundwater pumping because plutonium is tightly bound to sediments and not highly soluble or mobile within groundwater. This site continues to be monitored and provides a substantial base of information for evaluating plutonium mobility in Hanford groundwater.

The key conclusions from sample analyses for the 216-Z-9 Trench include the following.

- Studies with actual sediments collected beneath or near the 216-Z-9 Trench indicate that silt layers at approximately 65 and $115 \mathrm{ft}$ bgs significantly reduced the vertical advection of plutonium, americium, and TBP and likely resulted in horizontal spreading of the waste components along the tops of these layers during active disposal.

- The studies also indicate that plutonium and americium can only be mobilized from the 216-Z-9 Trench contaminated sediments by pore waters that remain acidic ( $\mathrm{pH} 4.3$ to 5.4) after contact with the sediments. Because an advective driving force is no longer present to transport the plutonium and americium, further subsurface migration of plutonium and americium does not appear to be likely.

- At waste sites within the 200-PW-1/3/6 OU, plutonium and americium were co-disposed with large volumes of acidic high-salt wastes that contained organic complexants. This practice resulted in significant transport through the vadose zone (up to $150 \mathrm{ft}$ bgs). The significant transport of plutonium and americium through the vadose zone was the result of the combination of high advective flux of the waste along with a high solubility and low sorption potential of plutonium and americium associated with low $\mathrm{pH}$ solutions. Association with dissolved organic complexing agents such as DBP may have added to the high mobility of plutonium and americium during the disposal phase of the site. In addition, it is possible that some fraction of the plutonium that migrated through the vadose zone may have been in particulate form.

- Under typical Hanford subsurface conditions [groundwater dominated by $\mathrm{Ca}, \mathrm{Na}$, and $\mathrm{HCO} 3-$ at near neutral $\mathrm{pH}(\sim 8)$, and oxidizing conditions], plutonium as the amorphous dioxide is relatively insoluble $(<10-8 \mathrm{M})$ and can adsorb strongly to Hanford sediments.

Major findings determined for americium and plutonium from studies conducted on the 216-Z-1A Crib are as follows.

- Reanalysis of a study conducted by Price et al. (1979) on the 216-Z-1A Crib demonstrated that plutonium-241 co-disposed with plutonium-239/240 in acidic high-salt wastes resulted in the in 
growth and subsequent mobilization of americium-241 relative to the plutonium isotopes. This is in contrast to the 216-B-5 Reverse Well where under near neutral conditions little separation occurred. The chemical behavior of plutonium-241 and plutonium-239/240 co-disposed in acidic high-salt wastes will be indistinguishable; however, because of the short half-life of plutonium-241, significant amounts of americium-241 will be produced as plutonium-241 decays. By comparing the depth profiles of americium-241 to plutonium-239/240, it became apparent that americium-241 was being transported preferentially relative to plutonium-239/240. These results suggest that at the 216-Z-1A Crib $\mathrm{Am}^{3+}$ was mobilized preferentially relative to $\mathrm{Pu}^{4+}$ (the most likely oxidation state present in the Hanford subsurface). In addition, comparison of plutonium-239/240 and americium-241

concentration depth profiles from the various wells indicated that lateral spreading of the liquid waste occurred along sediment layers. Lateral spreading was limited to a 10-m wide zone around the perimeter of the crib.

The Hanford Site has an extensive network of groundwater monitoring wells which have been monitored since operations began in the mid-1940s. To draw conclusions regarding subsurface mobility of plutonium at Hanford, it is essential to understand the relevant observations from groundwater monitoring results.

- Hanford's groundwater monitoring data are readily available on Hanford's Environmental Dashboard Application (http://environet.hanford.gov/eda/). Only three wells regularly show plutonium concentrations at or near drinking water standards. These are the three wells referred to above that are within a few meters of the 216-B-5 Reverse Well. Even with the liquid discharge of more than 11,000 $\mathrm{Ci}$ of plutonium-239 at Hanford (mostly to about a dozen sites associated with the PFP), there is little evidence of migration through the vadose zone to groundwater. There is no evidence of increasing concentrations of plutonium in groundwater from the few locations where plutonium has been detected in groundwater. 


\subsection{Speciation and Solubility of Plutonium and Americium in the Hanford Environment}

Understanding the speciation and solubility of plutonium and americium is key to understanding the behavior and fate of these two elements in the environment. Speciation relates to the particular chemical form that an element assumes and is dependent upon a number of factors including $\mathrm{pH}$, Eh, and solution composition in which the element is dissolved and the type of mineral surfaces to which the solution is in contact. Temperature and pressure can impact speciation, but for most near surface conditions, this effect is minor. Because mobilization of fixed contaminants (either precipitated within solid phases or adsorbed to mineral surfaces) to an aqueous phase is often the most likely route for human exposure and environmental impacts, developing a good understanding of speciation and its impact on plutonium and americium transport is imperative for assessing the potential risk of contaminant exposure.

In this section, we review the important aspects of speciation and solubility of plutonium and americium. The review is focused on conditions relevant to waste environments at the Hanford Site. A widely used fundamental approach to predicting the speciation of actinides is thermodynamic equilibrium modeling. In this approach, the free energy of the system is minimized to determine the most stable suite of species for a given solution composition. Several pitfalls can occur in this approach. In many instances, actinide ions in solution are not in a state of thermodynamic equilibrium. For example, for plutonium the crystalline oxide phase $\left[\mathrm{PuO}_{2}(\mathrm{c})\right]$ is often the most stable and least soluble phase; however, at room temperature this phase does not precipitate from solution, but rather a more soluble amorphous hydrated phase $\left[\mathrm{PuO}_{2} \cdot \mathrm{xH}_{2} \mathrm{O}\right.$ (am, hyd) or $\left.\mathrm{Pu}(\mathrm{OH})_{4}(\mathrm{am})\right]$ (Rai and Ryan 1982) is formed initially, becoming more crystalline and dehydrated with time. In other cases, slow reaction rates associated with certain redox reactions may prevent attainment of equilibrium. As a result of these complexities, careful consideration must be taken to account for these effects when conducting and interpreting speciation modeling results.

\subsection{Speciation and Solubility of Plutonium}

Many reviews that cover actinide geochemistry (including plutonium) in the environment have been published previously (e.g., Choppin 2007; Runde 2000; EPA 1999; Silva and Nitsche 1995; Allard et al. 1984). For conditions relevant to environments near the surface of the earth, plutonium can occur in four different oxidation states: $+3,+4,+5$, and +6 (Allard and Ryberg 1983). It is possible for all four of these oxidation states to occur in solution simultaneously (Cleveland 1979). Plutonium can exist in the $+4,+5$, and +6 oxidation states in environmentally relevant oxidizing conditions (Keeney-Kennicutt; Morse 1985), and in the +3 and +4 oxidation states under environmentally relevant reducing conditions. Under most environmental conditions, it appears that the +4 and +5 are the most stable oxidations states in the aqueous phase and +4 is the most stable oxidation state when adsorbed to mineral surfaces (Choppin and Morgenstern 2001). A number of factors can affect which oxidation states are most stable under a particular set of conditions. For example, lower oxidation states are stabilized by more acidic conditions while higher oxidation states are stabilized by basic conditions (Choppin 1983). Complexation can also alter the apparent redox stability. For example, the greater stability of complexes formed by $\mathrm{Pu}(\mathrm{IV})$ relative to $\mathrm{Pu}(\mathrm{III})$ can increase the apparent redox stability of $\mathrm{Pu}(\mathrm{IV})$ species relative to $\mathrm{Pu}(\mathrm{III})$. 
Dissolved plutonium forms complexes in solution with a variety of negatively charged ligands. The more important inorganic ligands of environmental significance include hydroxide, carbonate, fluoride, hydrogen phosphate, di-hydrogen phosphate and sulfate. Complexes with naturally occurring organic ligands such as humic and fulvic acids, and low molecular weight organic acids (e.g., oxalate, acetate, citrate) are also known. For a given oxidation state, the stability of plutonium complexes with various ligands follows the following trend (Silva and Nitsche 1995):

$$
\mathrm{OH}^{-}, \mathrm{CO}_{3}{ }^{2-},>\mathrm{F}^{-}, \mathrm{HPO}_{4}{ }^{2-}, \mathrm{SO}_{4}{ }^{2-},>\mathrm{Cl}^{-}, \mathrm{NO}_{3}{ }^{-} .
$$

It is well known that $\mathrm{Pu}(\mathrm{IV})$ forms the most stable complexes, while $\mathrm{Pu}(\mathrm{V})$ form the weakest. For example, the relative stability of the four oxidation states of interest for plutonium decreases according to the following sequence (Lemire et al. 2001):

$$
\mathrm{Pu}(\mathrm{IV})>\mathrm{Pu}(\mathrm{VI})>\mathrm{Pu}(\mathrm{III})>\mathrm{Pu}(\mathrm{V})
$$

The reason for this sequence in complex stability is not readily apparent from oxidation state considerations alone. For the III and IV oxidation states, plutonium forms hydrated ions $\mathrm{Pu}^{3+}$ and $\mathrm{Pu}^{4+}$ in solution. The highly charged plutonium ions in the $\mathrm{V}$ and $\mathrm{VI}$ oxidation states are not stable in solution and hydrolyze to form linear trans-dioxo cations, $\mathrm{PuO}_{2}{ }^{+}$and $\mathrm{PuO}_{2}{ }^{2+}$. The covalent bonding between the plutonium and oxygen atoms enhances the effective charge of the central plutonium ion to 2.3 for $\mathrm{PuO}_{2}{ }^{+}$ and 3.3 for $\mathrm{PuO}_{2}{ }^{2+}$ (Runde 2000; Choppin 1983). With these considerations, the reason for the sequence of complex stability is readily apparent:

$$
\begin{array}{cccc}
\mathrm{Pu}^{4+}>\mathrm{PuO}_{2}{ }^{2+}>\mathrm{Pu}^{3+}>\mathrm{PuO}_{2}^{+} \\
+4 & +3.3 & +3 & +2.3 \\
\text { IV } & \text { VI } & \text { III } & \mathrm{V}
\end{array}
$$

The second line shows the effective charge of the respective ion, while the third line indicates the formal oxidation state.

Because $\mathrm{Pu}^{4+}$ has the highest effective charge, it forms the most stable complexes in solution and also forms the most stable precipitates having the lowest solubility. In contrast, $\mathrm{PuO}_{2}{ }^{+}$complexes are the weakest and its precipitates are the most soluble.

\subsubsection{Plutonium Disproportionation Reactions}

As demonstrated in the previous section, oxidation states play a crucial role in the speciation and solubility of plutonium which in turn significantly affects its behavior in the environment. Disproportionation reactions are a significant aspect of plutonium chemistry that leads to several oxidation states being in solution simultaneously (Cleveland 1979). Disproportionation of plutonium in various acidic media has been described in a number of studies (Connick 1949; Connick and McVey 1953; Rabideau 1953; Rabideau and Cowan 1955; Lavallee and Newton 1972; Costanzo et al. 1973; Toth et al. 1990; Haschke 2007; Shilov et al. 2011).

Uncertainties still exist in our ability to quantitatively model plutonium disproportionation reactions (Silver 2011); however, for most environmentally relevant conditions in natural waters, these reactions are not a factor (Choppin and Morgenstern 2001). Because disproportionation reactions are bimolecular, 
they are dependent upon the square of the concentration of the disproportionating species. As a result, as plutonium concentrations in solution decrease, the probability of these reactions being significant diminishes dramatically. In addition, any radiolytically induced redox reactions are minimal at concentrations less than $\sim 10^{-6} \mathrm{M}$ (Runde 2000). The impact of radiolysis generated redox reactions could be important at locations where significant concentrations of solid plutonium precipitates occur such as at the bottom of the 216-Z-9 Trench.

\subsubsection{Plutonium Speciation and Solubility Calculations Relevant to Hanford}

In this section, we provide results of thermodynamic equilibrium speciation and solubility calculations for a range of conditions considered relevant to various Hanford waste site conditions or scenarios. The results are presented graphically for ease of interpretation. In order to conduct accurate speciation and solubility calculations, it is critical that the thermodynamic data used are accurate, complete and internally consistent in terms of all the potentially important species and solid phases. Because these data are constantly being revised and updated, the data that were used in the present calculations are documented in Table 4.1.

Figure 4.1 is an Eh pH diagram for plutonium at a concentration of $10^{-12} \mathrm{M}(15 \mathrm{pCi} / \mathrm{L}$, the MCL) in pure water. For these conditions, plutonium is completely soluble and $\mathrm{Pu}$ (III) species dominate at lower $\mathrm{pH}$ and Eh values. At intermediate $\mathrm{pH}$ values and low $\mathrm{Eh}$, and at high $\mathrm{pH}, \mathrm{Pu}(\mathrm{IV})$ species are dominant. At neutral $\mathrm{pH}$ values and above $\mathrm{Pu}^{4+}$ is completely hydrolyzed to the $\mathrm{Pu}(\mathrm{OH})_{4}(\mathrm{aq})$ species. $\mathrm{Pu}(\mathrm{V})$ at high Eh values at moderate to low $\mathrm{pH}$ values and $\mathrm{Pu}(\mathrm{VI})$ dominates at high Eh values under acidic and basic conditions.

Increasing the plutonium concentration to $10^{-10} \mathrm{M}(1,500 \mathrm{pCi} / \mathrm{L})$ results in precipitation of the solid phase $\mathrm{PuO}_{2}$ (hyd,aged) (Figure 4.2). For these conditions, the stability field for the solid covers an extensive range. Above $\mathrm{pH} 6$, this solid phase dominates over nearly the entire range of Eh.

To evaluate the impact of ligands that are commonly present in a hypothetical Hanford Site groundwater, another diagram was constructed using the following major component concentrations: $2 \times 10^{-3} \mathrm{M} \mathrm{HCO}_{3}^{-}, 10^{-3} \mathrm{M} \mathrm{Cl}^{-}, 5 \times 10^{-4} \mathrm{M} \mathrm{SO}_{4}{ }^{2-}, 10^{-6}$ and $10^{-7} \mathrm{M} \mathrm{HPO}_{4}{ }^{2-}, 10^{-3} \mathrm{M} \mathrm{Na}^{+}, 2 \times 10^{-3} \mathrm{M} \mathrm{Ca}^{2+}$, and $5 \times 10^{-4} \mathrm{M} \mathrm{Mg}^{2+}$ (Figure 4.3). The most significant change in speciation for this diagram is that a new stability field for the solid phase $\mathrm{PuPO}_{4}(\mathrm{~s}$, hyd) appears between $\mathrm{pH}$ values of approximately four to ten at intermediate to low Eh values. In addition, the stability fields for $\mathrm{Pu}(\mathrm{VI})$ species have increased as a result of carbonate complexation and the stability fields for $\mathrm{Pu}(\mathrm{IV})$ has increased at low $\mathrm{pH}$ values as a result of fluoride complexation.

Figure 4.4 was constructed for the same conditions as Figure 4.3 with the exception that the total $\mathrm{HPO}_{4}{ }^{2-}$ concentration was increased to $10^{-5} \mathrm{M}$. In this case, the stability field of $\mathrm{PuPO}_{4}(\mathrm{~s}$, hyd) increases to $\mathrm{pH}$ values as low as approximately 3 . In addition, a new plutonium(IV) phase $\left[\mathrm{Pu}\left(\mathrm{HPO}_{2}\right)_{2}(\mathrm{~s})\right]$ becomes stable under oxidizing conditions at $\mathrm{pH}$ values of less than 3 . 
Table 4.1. Plutonium Thermodynamic Data Used in Speciation and Solubility Calculations (298.15 K, $0.1 \mathrm{Mpa}$ )

\begin{tabular}{|c|c|c|}
\hline Reaction & $\log \mathrm{K}^{\circ}(\mathrm{I}=0)$ & Source \\
\hline $\mathrm{Pu}^{3+}+\mathrm{H}_{2} \mathrm{O}=\mathrm{PuOH}^{2+}+\mathrm{H}^{+}$ & -6.900 & (a) \\
\hline $\mathrm{Pu}^{3+}+\mathrm{SO}_{4}^{2-}=\mathrm{PuSO}_{4}^{+}$ & 3.832 & (a) \\
\hline $\mathrm{Pu}^{3+}+2 \mathrm{SO}_{4}{ }^{2-}=\mathrm{Pu}\left(\mathrm{SO}_{4}\right)_{2}^{-}$ & 5.544 & (a) \\
\hline $\mathrm{Pu}^{3+}+3 \mathrm{H}_{2} \mathrm{O}=\mathrm{Pu}(\mathrm{OH})_{3}(\mathrm{cr})+3 \mathrm{H}^{+}$ & -15.800 & (a) \\
\hline $\mathrm{Pu}^{3+}+\mathrm{HPO}_{4}{ }^{2-}=\mathrm{PuPO}_{4}(\mathrm{~s}$, hyd $)+\mathrm{H}^{+}$ & 12.250 & (a) \\
\hline $\mathrm{Pu}^{4+}+\mathrm{H}_{2} \mathrm{O}=\mathrm{PuOH}^{3+}+\mathrm{H}^{+}$ & -0.600 & (b) \\
\hline $\mathrm{Pu}^{4+}+2 \mathrm{H}_{2} \mathrm{O}=\mathrm{Pu}(\mathrm{OH})_{2}{ }^{2+}+2 \mathrm{H}^{+}$ & 0.600 & (b) \\
\hline $\mathrm{Pu}^{4+}+3 \mathrm{H}_{2} \mathrm{O}=\mathrm{Pu}(\mathrm{OH})_{3}{ }^{2+}+3 \mathrm{H}^{+}$ & -2.300 & (b) \\
\hline $\mathrm{Pu}^{4+}+4 \mathrm{H}_{2} \mathrm{O}=\mathrm{Pu}(\mathrm{OH})_{4}(\mathrm{aq})+4 \mathrm{H}^{+}$ & -8.500 & (b) \\
\hline $\mathrm{Pu}^{4+}+\mathrm{F}^{-}=\mathrm{PuF}^{3+}$ & 8.840 & (a) \\
\hline $\mathrm{Pu}^{4+}+2 \mathrm{~F}^{-}=\mathrm{PuF}_{2}^{2+}$ & 15.700 & (a) \\
\hline $\mathrm{Pu}^{4+}+\mathrm{SO}_{4}{ }^{2-}=\mathrm{PuSO}_{4}{ }^{2+}$ & 6.812 & (a) \\
\hline $\mathrm{Pu}^{4+}+2 \mathrm{SO}_{4}{ }^{2-}=\mathrm{Pu}\left(\mathrm{SO}_{4}\right)_{2}(\mathrm{aq})$ & 10.984 & (a) \\
\hline $\mathrm{Pu}^{4+}+4 \mathrm{HCO}_{3}{ }^{2-}=\mathrm{Pu}\left(\mathrm{CO}_{3}\right)_{4}^{4-}+4 \mathrm{H}^{+}$ & -4.315 & (b) \\
\hline $\mathrm{Pu}^{4+}+5 \mathrm{HCO}_{3}^{-}=\mathrm{Pu}\left(\mathrm{CO}_{3}\right)_{5}^{6-}+5 \mathrm{H}^{+}$ & -16.067 & (b) \\
\hline $\mathrm{Pu}^{4+}+\mathrm{HPO}_{4}^{2-}+2 \mathrm{H}^{+}=\mathrm{PuH}_{3} \mathrm{PO}_{4}^{4+}$ & 11.732 & (a) \\
\hline $\mathrm{Pu}^{4+}+4 \mathrm{H}_{2} \mathrm{O}=\mathrm{PuO}_{2}$ (hydr, aged $)+4 \mathrm{H}^{+}$ & 1.980 & (a) \\
\hline $\mathrm{Pu}^{4+}+4 \mathrm{H}_{2} \mathrm{O}=\mathrm{PuO}_{2}(\mathrm{c})+4 \mathrm{H}^{+}$ & 8.017 & (a) \\
\hline $\mathrm{Pu}^{4+}+2 \mathrm{HPO}_{4}{ }^{2-}=\mathrm{Pu}\left(\mathrm{HPO}_{4}\right)_{2}(\mathrm{am}, \mathrm{hyd})$ & 30.450 & (a) \\
\hline $\mathrm{PuO}_{2}^{+}+\mathrm{H}_{2} \mathrm{O}=\mathrm{PuO}_{2} \mathrm{OH}(\mathrm{aq})+\mathrm{H}^{+}$ & -9.730 & (a) \\
\hline $\mathrm{PuO}_{2}^{+}+\mathrm{HCO}_{3}^{2-}=\mathrm{PuO}_{2} \mathrm{CO}_{3}^{-}+\mathrm{H}^{+}$ & -5.223 & (a) \\
\hline $\mathrm{PuO}_{2}{ }^{+}+3 \mathrm{HCO}_{3}{ }^{2-}=\mathrm{PuO}_{2}\left(\mathrm{CO}_{3}\right)_{3}{ }^{5-}+3 \mathrm{H}^{+}$ & -26.005 & (a) \\
\hline $\mathrm{PuO}_{2}^{+}+\mathrm{H}_{2} \mathrm{O}=\mathrm{PuO}_{2} \mathrm{OH}(\mathrm{am})+\mathrm{H}^{+}$ & -5.000 & (a) \\
\hline $\mathrm{PuO}_{2}^{2+}+\mathrm{H}_{2} \mathrm{O}=\mathrm{PuO}_{2} \mathrm{OH}^{+}+\mathrm{H}^{+}$ & -5.500 & (a) \\
\hline $\mathrm{PuO}_{2}{ }^{2+}+2 \mathrm{H}_{2} \mathrm{O}=\mathrm{PuO}_{2}(\mathrm{OH})_{2}(\mathrm{aq})+2 \mathrm{H}^{+}$ & -13.200 & (a) \\
\hline $\mathrm{PuO}_{2}^{2+}+\mathrm{F}^{-}=\mathrm{PuO}_{2} \mathrm{~F}^{+}+\mathrm{H}^{+}$ & 4.560 & (a) \\
\hline $\mathrm{PuO}_{2}^{2+}+2 \mathrm{~F}^{-}=\mathrm{PuO}_{2}(\mathrm{~F})_{2}(\mathrm{aq})$ & 7.250 & (a) \\
\hline $\mathrm{PuO}_{2}{ }^{2+}+\mathrm{SO}_{4}{ }^{2-}=\mathrm{PuO}_{2} \mathrm{SO}_{4}(\mathrm{aq})$ & 3.380 & (a) \\
\hline $\mathrm{PuO}_{2}{ }^{2+}+2 \mathrm{SO}_{4}{ }^{2-}=\mathrm{PuO}_{2}\left(\mathrm{SO}_{4}\right)^{2-}$ & 4.400 & (a) \\
\hline $\mathrm{PuO}_{2}{ }^{2+}+\mathrm{HCO}_{3}^{2-}=\mathrm{PuO}_{2} \mathrm{CO}_{3}(\mathrm{aq})+\mathrm{H}^{+}$ & 1.257 & (a) \\
\hline $\mathrm{PuO}_{2}{ }^{2+}+2 \mathrm{HCO}_{3}{ }^{2-}=\mathrm{PuO}_{2}\left(\mathrm{CO}_{3}\right)_{2}{ }^{2-}+2 \mathrm{H}^{+}$ & -6.187 & (a) \\
\hline $\mathrm{PuO}_{2}^{2+}+3 \mathrm{HCO}_{3}^{2-}=\mathrm{PuO}_{2}\left(\mathrm{CO}_{3}\right)_{3}^{4-}+3 \mathrm{H}^{+}$ & -13.330 & (a) \\
\hline $\mathrm{PuO}_{2}{ }^{2+}+3 \mathrm{H}_{2} \mathrm{O}=\mathrm{PuO}_{2}(\mathrm{OH})_{2} \cdot \mathrm{H}_{2} \mathrm{O}(\mathrm{cr})+2 \mathrm{H}^{+}$ & -5.500 & (a) \\
\hline $\mathrm{PuO}_{2}^{2+}+\mathrm{HCO}_{3}^{2-}=\mathrm{PuO}_{2} \mathrm{CO}_{3}(\mathrm{~s})+\mathrm{H}^{+}$ & 3.857 & (a) \\
\hline
\end{tabular}

(a) Lemire et al. (2001).

(b) Guillaumont et al. (2003). 


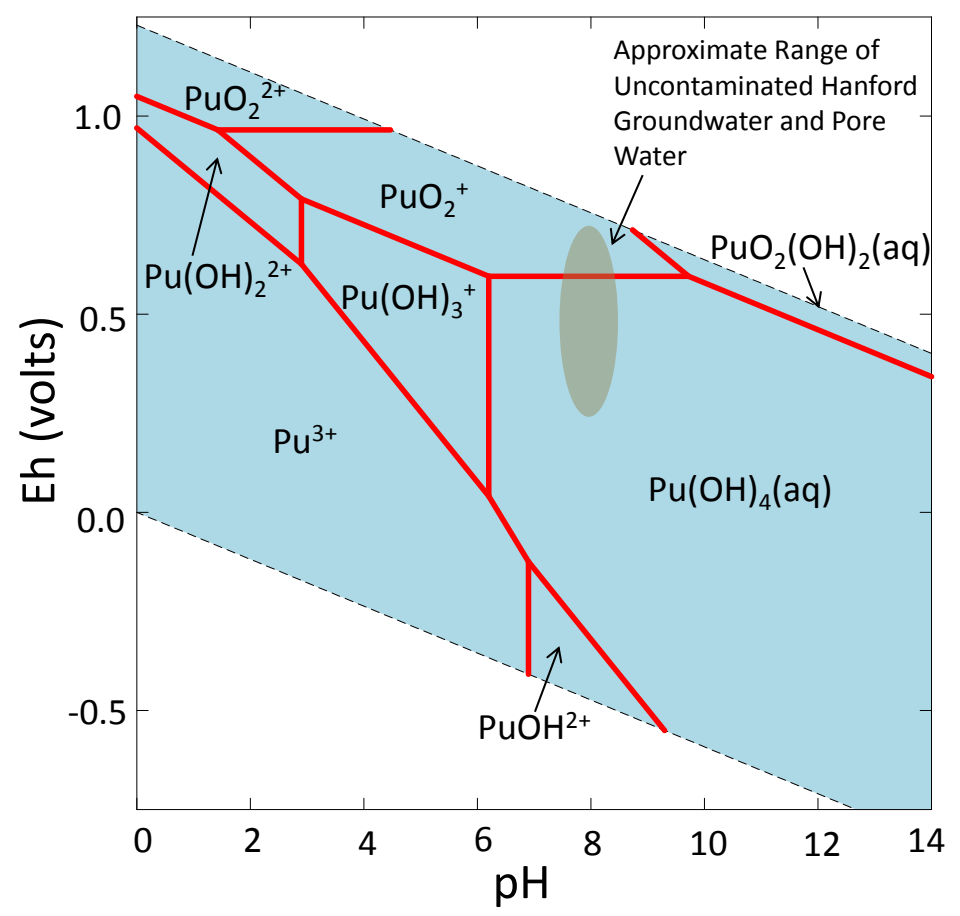

Figure 4.1. Eh $\mathrm{pH}$ Diagram for Plutonium at a Concentration of $10^{-12} \mathrm{M}(15 \mathrm{pCi} / \mathrm{L}$, the MCL) in Pure Water $(298.15 \mathrm{~K}, 0.1 \mathrm{Mpa})$

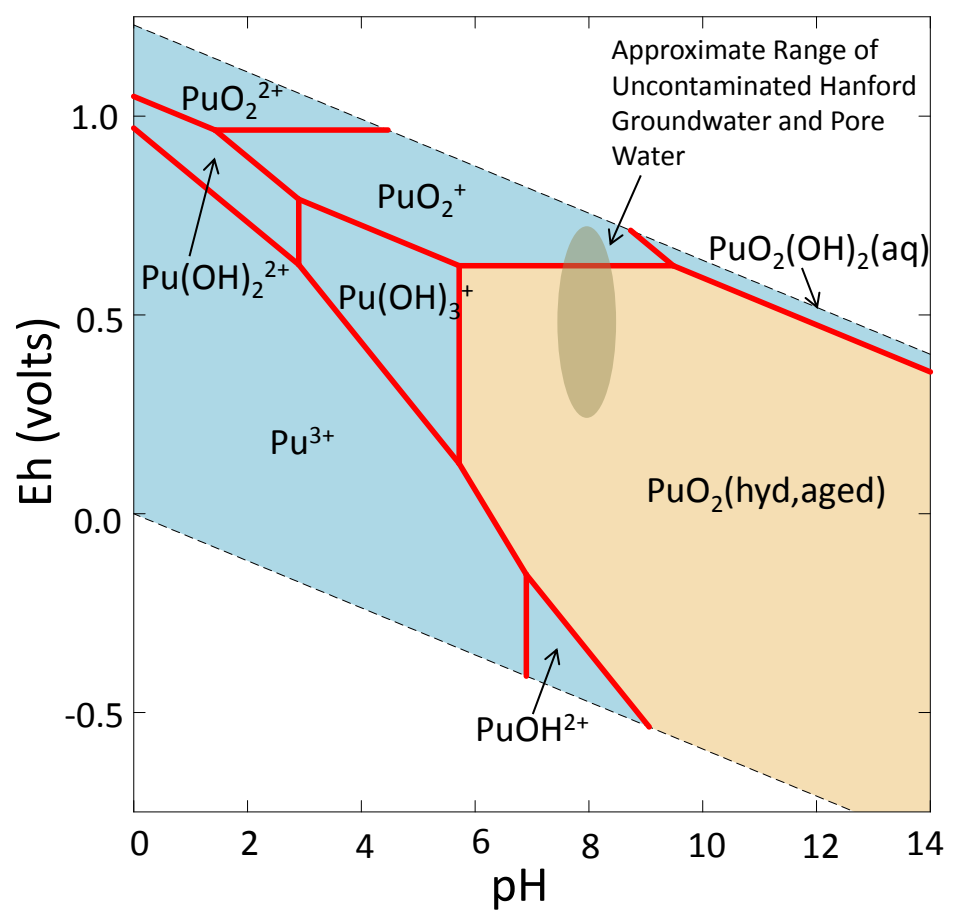

Figure 4.2. Eh $\mathrm{pH}$ Diagram for Plutonium at a Concentration of $10^{-10} \mathrm{M}(1,500 \mathrm{pCi} / \mathrm{L}$, the $\mathrm{MCL})$ in Pure Water $(298.15 \mathrm{~K}, 0.1 \mathrm{Mpa})$ 


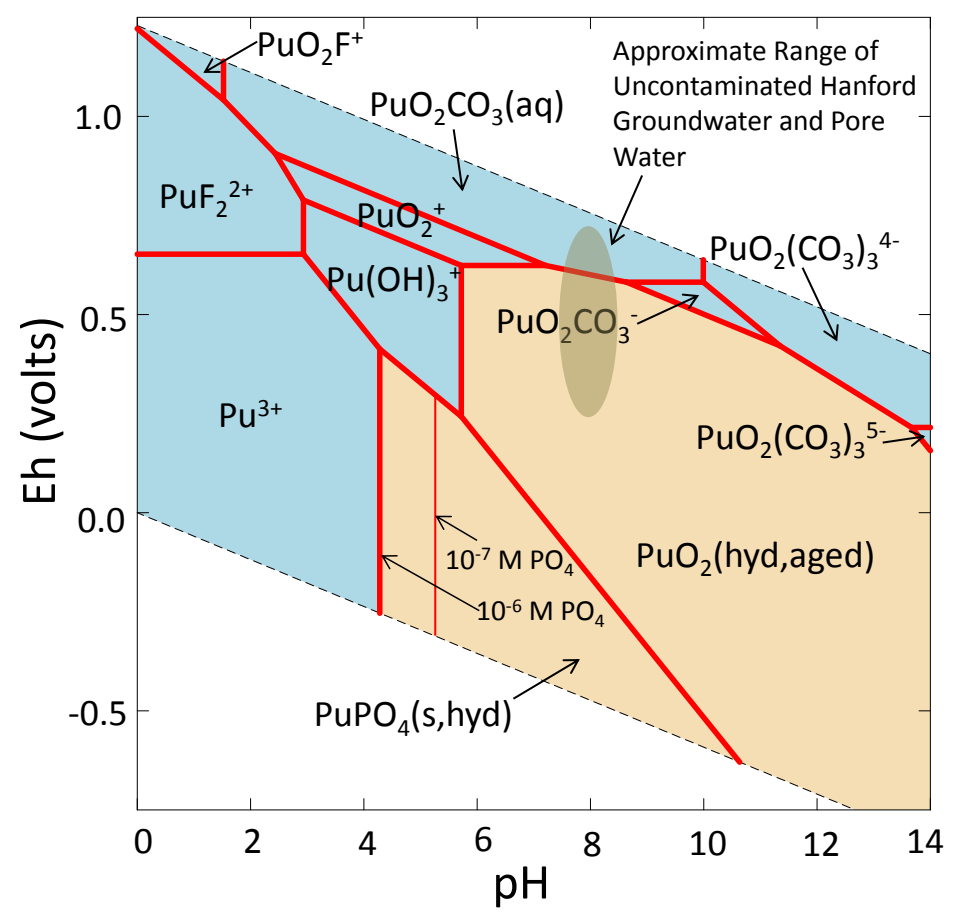

Figure 4.3. Eh $\mathrm{pH}$ Diagram for Plutonium at a Concentration of $10^{-10} \mathrm{M}(1,500 \mathrm{pCi} / \mathrm{L}$, the MCL) in a Hypothetical Hanford Site Groundwater with a Composition of $2 \times 10^{-3} \mathrm{M} \mathrm{HCO}_{3}^{-}$,

$10^{-3} \mathrm{M} \mathrm{Cl}^{-}, 5 \times 10^{-4} \mathrm{M} \mathrm{SO}_{4}{ }^{2-}, 10^{-6} \mathrm{M} \mathrm{HPO}_{4}{ }^{2-}\left(10^{-7} \mathrm{M} \mathrm{HPO}_{4}{ }^{2-}\right), 10^{-3} \mathrm{M} \mathrm{Na}^{+}, 2 \times 10^{-3} \mathrm{M} \mathrm{Ca}^{2+}$, and $5 \times 10^{-4} \mathrm{M} \mathrm{Mg}^{2+}(298.15 \mathrm{~K}, 0.1 \mathrm{Mpa})$

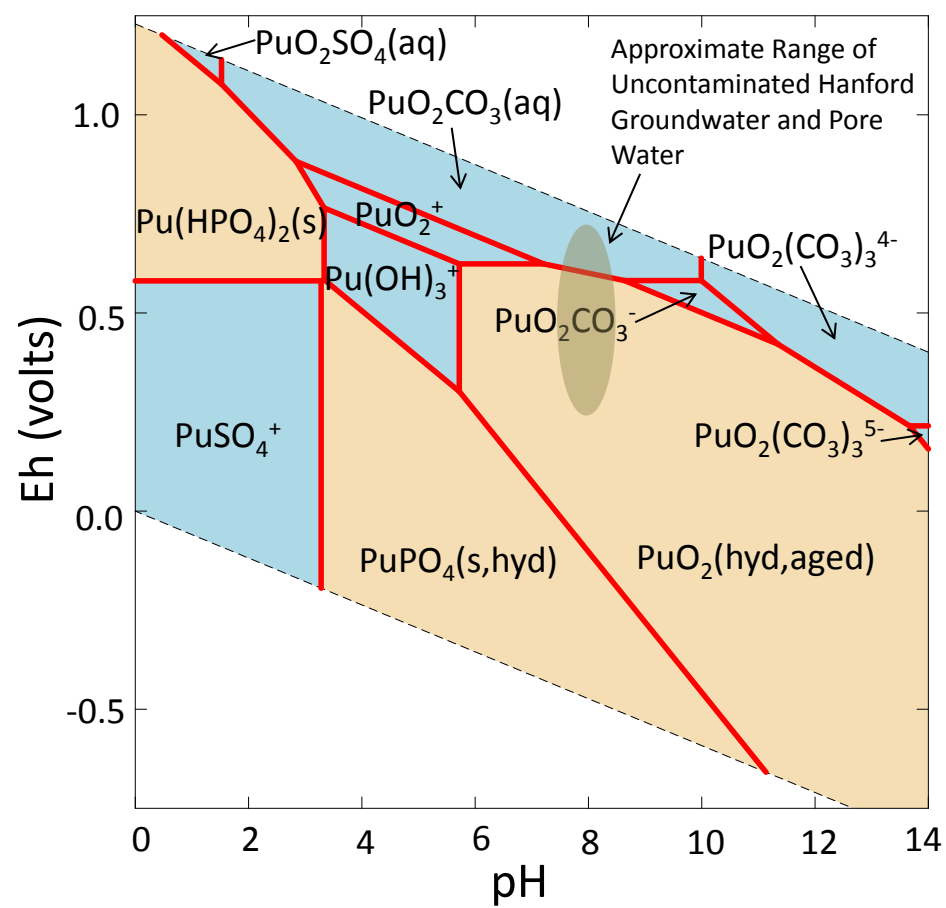

Figure 4.4. Eh $\mathrm{pH}$ Diagram for Plutonium at a Concentration of $10^{-10} \mathrm{M}(1,500 \mathrm{pCi} / \mathrm{L}$, the $\mathrm{MCL})$ in a Hypothetical Hanford Site Groundwater with a Composition of $2 \times 10^{-3} \mathrm{M} \mathrm{HCO}_{3}^{-}$, $10^{-3} \mathrm{M} \mathrm{Cl}^{-}, 5 \times 10^{-4} \mathrm{M} \mathrm{SO}_{4}{ }^{2-}, 10^{-5} \mathrm{M} \mathrm{HPO}_{4}{ }^{2-}, 10^{-3} \mathrm{M} \mathrm{Na}^{+}, 2 \times 10^{-3} \mathrm{M} \mathrm{Ca}^{2+}$, and $5 \times 10^{-4} \mathrm{M} \mathrm{Mg}^{2+}(298.15 \mathrm{~K}, 0.1 \mathrm{Mpa})$ 


\subsubsection{Hyperstoichiometric Plutonium Oxide}

For the calculation performed in Section 4.1.2, $\mathrm{PuO}_{2}$ (hyd,aged) was assumed to be the most stable oxide phase for $\mathrm{Pu}(\mathrm{IV})$. In the past, $\mathrm{PuO}_{2}$ has always been thought to be the highest stable oxide of plutonium (Keller 1973; Morss 1986). More recently plutonium dioxide $\left(\mathrm{PuO}_{2}\right)$ has been found to react with water to form higher oxides up to $\mathrm{PuO}_{2.27}$ (Haschke et al. 2000). Subsequently, Korzhavyi et al. (2004) performed calculations that indicate reactions of $\mathrm{PuO}_{2}$ with either $\mathrm{O}_{2}$ or $\mathrm{H}_{2} \mathrm{O}$ to form $\mathrm{PuO}_{2+\mathrm{x}}$ are endothermic (require energy to form) and therefore are not likely to occur. Additional calculations showed that $\mathrm{PuO}_{2+\mathrm{x}}$ can form as an intermediate product through reactions with radiolysis products of water, such as $\mathrm{H}_{2} \mathrm{O}_{2}$ (Korzhavyi et al. 2004). These results indicate that thermodynamic solubility calculations determined assuming $\mathrm{PuO}_{2}$ (hyd,aged) is the most stable oxide phase of $\mathrm{Pu}(\mathrm{IV})$ may produce incorrect results for environments where the radiation field is high enough to produce significant concentrations of radiolysis products such as $\mathrm{H}_{2} \mathrm{O}_{2}$. The bottom of the 216-Z-9 Trench is an example of where this process could potentially have an impact.

\subsection{Speciation and Solubility of Americium}

The environmental chemistry of americium is much less complicated than that of plutonium. Americium can exist in the $+3,+4,+5$, and +6 oxidation states; however, Am(III) is the most stable under environmentally relevant conditions. As was the case for plutonium, the more important inorganic ligands of environmental significance for americium include hydroxide, carbonate, fluoride, hydrogen phosphate, di-hydrogen phosphate, and sulfate. For typical Hanford Site conditions, carbonate complexes are the dominant species in solution. Americium complexes with naturally occurring organic ligands such as humic and fulvic acids, and low molecular weight organic acids (e.g., oxalate, acetate, and citrate) are also known. Under typical Hanford Site groundwater conditions (low dissolved organic carbon concentration, neutral to alkaline $\mathrm{pH}$, and high calcium concentrations), the impact of humic substances on actinide speciation can be neglected (Moulin et al. 1988, 1992).

\subsubsection{Americium Speciation and Solubility Calculations Relevant to Hanford}

As was done previously for plutonium, americium thermodynamic equilibrium speciation and solubility calculations for a range of conditions considered relevant to various Hanford Site waste site conditions or scenarios were performed. The thermodynamic data that were used in the present calculations are provided in Table 4.2.

Figure 4.5 is a speciation diagram for americium calculated for a concentration of $10^{-12} \mathrm{M}$ $(830 \mathrm{pCi} / \mathrm{L})$ in pure water. For these conditions, americium occurs entirely in the Am(III) oxidation state. Am(III) begins to hydrolyze (form hydroxide complexes) at $\mathrm{pH}$ values above 6 and becomes increasingly hydrolyzed as $\mathrm{pH}$ increases.

To evaluate the impact of ligands that are commonly present in a hypothetical Hanford Site groundwater, another diagram was constructed using the following major component concentrations $2 \times 10^{-3} \mathrm{M} \mathrm{HCO}_{3}{ }^{-}, 10^{-3} \mathrm{M} \mathrm{Cl}^{-}, 5 \times 10^{-4} \mathrm{M} \mathrm{SO}_{4}{ }^{2-}, 10^{-6} \mathrm{M} \mathrm{HPO}_{4}{ }^{2-}, 10^{-3} \mathrm{M} \mathrm{Na}^{+}, 2 \times 10^{-3} \mathrm{M} \mathrm{Ca}^{2+}$, and $5 \times$ $10^{-4} \mathrm{M} \mathrm{Mg}^{2+}$ (Figure 4.6). The most significant change in speciation for this diagram is that carbonate complexes dominate the speciation of americium between $\mathrm{pH}$ values approximately 6 to 9 . 
Table 4.2. Americium Thermodynamic Data Used in Speciation and Solubility Calculations (298.15 K, $0.1 \mathrm{Mpa}$ )

\begin{tabular}{|c|c|c|}
\hline Reaction & $\log K^{\circ}(I=0)$ & Source \\
\hline $\mathrm{Am}^{3+}+\mathrm{H}_{2} \mathrm{O}=\mathrm{AmOH}^{2+}+\mathrm{H}^{+}$ & -7.200 & (a) \\
\hline $\mathrm{Am}^{3+}+2 \mathrm{H}_{2} \mathrm{O}=\mathrm{Am}(\mathrm{OH})_{2}^{+}+2 \mathrm{H}^{+}$ & -15.100 & (a) \\
\hline $\mathrm{Am}^{3+}+3 \mathrm{H}_{2} \mathrm{O}=\mathrm{Am}(\mathrm{OH})_{3}(\mathrm{aq})+3 \mathrm{H}^{+}$ & -26.200 & (a) \\
\hline $\mathrm{Am}^{3+}+\mathrm{F}^{-}=\mathrm{AmF}^{2+}$ & 3.400 & (a) \\
\hline $\mathrm{Am}^{3+}+2 \mathrm{~F}^{-}=\mathrm{AmF}_{2}^{+}$ & 5.800 & (a) \\
\hline $\mathrm{Am}^{3+}+\mathrm{SO}_{4}{ }^{2-}=\mathrm{AmSO}_{4}^{+}$ & 3.300 & (a) \\
\hline $\mathrm{Am}^{3+}+2 \mathrm{SO}_{4}^{2-}=\mathrm{Am}\left(\mathrm{SO}_{4}\right)_{2}^{-}$ & 3.700 & (a) \\
\hline $\mathrm{Am}^{3+}+\mathrm{HPO}_{4}{ }^{2-}+\mathrm{H}^{+}=\mathrm{AmH}_{2} \mathrm{PO}_{4}{ }^{2+}$ & 10.205 & (a) \\
\hline $\mathrm{Am}^{3+}+\mathrm{HCO}_{3}^{-}=\mathrm{AmCO}_{3}^{+}+\mathrm{H}^{+}$ & -2.329 & (a) \\
\hline $\mathrm{Am}^{3+}+2 \mathrm{HCO}_{3}^{-}=\mathrm{Am}\left(\mathrm{CO}_{3}\right)_{2}^{-}+2 \mathrm{H}^{+}$ & -7.758 & (a) \\
\hline $\mathrm{Am}^{3+}+3 \mathrm{HCO}_{3}^{-}=\mathrm{Am}\left(\mathrm{CO}_{3}\right)_{3}{ }^{3-}+3 \mathrm{H}^{+}$ & -15.986 & (a) \\
\hline $\mathrm{Am}^{3+}+3 \mathrm{H}_{2} \mathrm{O}=\mathrm{Am}(\mathrm{OH})_{3}(\mathrm{am})+3 \mathrm{H}^{+}$ & -16.900 & (a) \\
\hline $\mathrm{Am}^{3+}+3 \mathrm{H}_{2} \mathrm{O}=\mathrm{Am}(\mathrm{OH})_{3}(\mathrm{cr})+3 \mathrm{H}^{+}$ & -15.600 & (a) \\
\hline $\mathrm{Am}^{3+}+\mathrm{HPO}_{4}{ }^{2-}=\mathrm{AmPO}_{4}(\mathrm{am}, \mathrm{hyd})+\mathrm{H}^{+}$ & 12.468 & (a) \\
\hline $2 \mathrm{Am}^{3+}+3 \mathrm{HCO}_{3}^{-}=\mathrm{Am}_{2}\left(\mathrm{CO}_{3}\right)_{3}(\mathrm{am})+3 \mathrm{H}^{+}$ & -14.286 & (a) \\
\hline $\mathrm{Am}^{3+}+\mathrm{HCO}_{3}^{-}+1.5 \mathrm{H}_{2} \mathrm{O}=\mathrm{AmCO}_{3} \mathrm{OH} \cdot 0.5 \mathrm{H}_{2} \mathrm{O}(\mathrm{cr})+2 \mathrm{H}^{+}$ & -1.924 & (a) \\
\hline $\mathrm{Am}^{3+}+\mathrm{HCO}_{3}^{-}+\mathrm{H}_{2} \mathrm{O}=\mathrm{AmCO}_{3} \mathrm{OH}(\mathrm{am}, \mathrm{hyd})+2 \mathrm{H}^{+}$ & -4.124 & (a) \\
\hline $\mathrm{Am}^{4+}+2 \mathrm{H}_{2} \mathrm{O}=\mathrm{AmO}_{2}(\mathrm{cr})+4 \mathrm{H}^{+}$ & 9.420 & (b) \\
\hline
\end{tabular}

(a) Guillaumont et al. (2003).

(b) Silva et al. (1995).

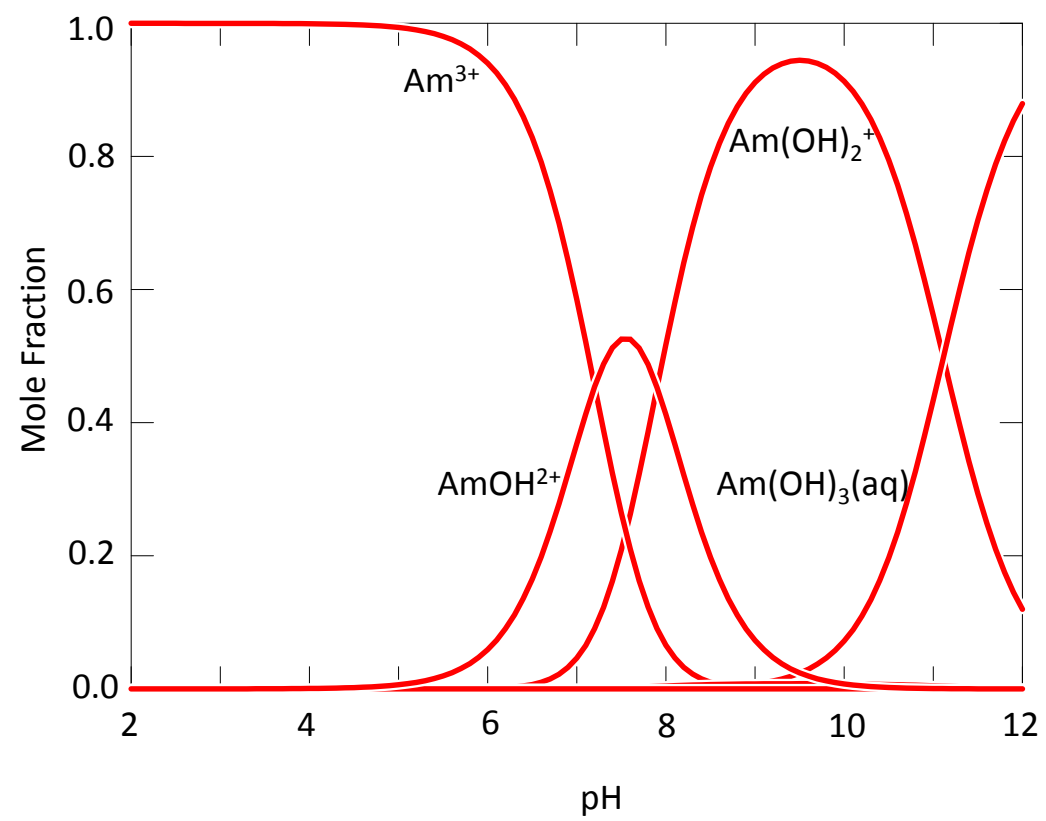

Figure 4.5. Distribution of Americium Species at a Concentration of $10^{-12} \mathrm{M}(830 \mathrm{pCi} / \mathrm{L})$ in Pure Water (298.15 K, 0.1 Mpa) 


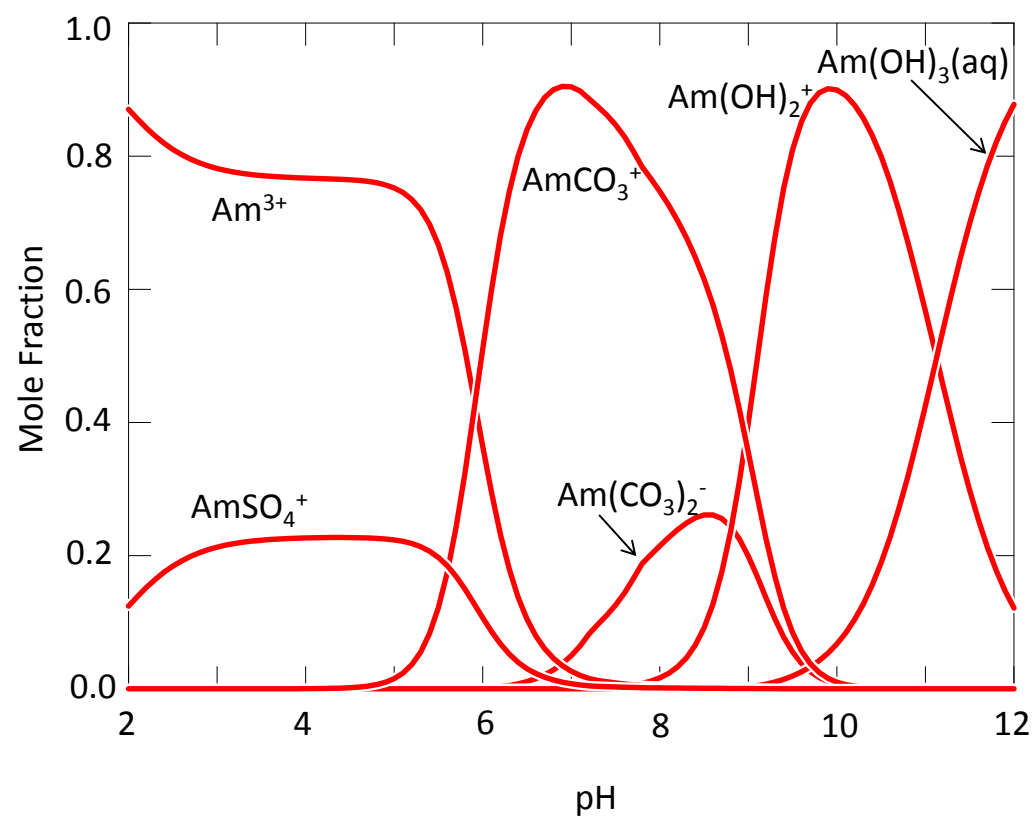

Figure 4.6. Distribution of Americium Species at a Concentration of $10^{-12} \mathrm{M}(830 \mathrm{pCi} / \mathrm{L})$ in a Hypothetical Hanford Site Groundwater with a Composition of $2 \times 10^{-3} \mathrm{M} \mathrm{HCO}_{3}^{-}$, $10^{-3} \mathrm{M} \mathrm{Cl}^{-}, 5 \times 10^{-4} \mathrm{M} \mathrm{SO}_{4}{ }^{2-}, 10^{-6} \mathrm{M} \mathrm{HPO}_{4}{ }^{2-}, 10^{-3} \mathrm{M} \mathrm{Na}^{+}, 2 \times 10^{-3} \mathrm{M} \mathrm{Ca}^{2+}$, and $5 \times 10^{-4} \mathrm{M} \mathrm{Mg}^{2+}(298.15 \mathrm{~K}, 0.1 \mathrm{Mpa})$

Figure 4.7 is a solubility diagram for americium phases for a hypothetical Hanford Site groundwater with the following major component concentrations: $2 \times 10^{-3} \mathrm{M} \mathrm{HCO}_{3}^{-}, 10^{-3} \mathrm{M} \mathrm{Cl}^{-}, 5 \times 10^{-4} \mathrm{M} \mathrm{SO}_{4}^{2-}$, $10^{-3} \mathrm{M} \mathrm{Na}^{+}, 2 \times 10^{-3} \mathrm{M} \mathrm{Ca}^{2+}$, and $5 \times 10^{-4} \mathrm{M} \mathrm{Mg}^{2+}$. Note that $\mathrm{HPO}_{4}{ }^{2-}$ was not included in this second groundwater composition. Under these conditions, the solid, $\mathrm{AmOHCO}_{3} \cdot 0.5 \mathrm{H}_{2} \mathrm{O}(\mathrm{cr})$, is the dominant precipitate until the $\mathrm{pH}$ increases to approximately 11 . Above $\mathrm{pH} 11, \mathrm{AmO}_{2}$ becomes the most stable precipitate.

Figure 4.8 is a solubility diagram for americium phases for a the hypothetical Hanford Site groundwater except that in this case $\mathrm{HPO}_{4}{ }^{2-}$ at a concentration of $10^{-6} \mathrm{M}$ was included. Under these conditions, the solid, $\mathrm{AmPO}_{4}(\mathrm{am})$, is the most stable precipitate for the $\mathrm{pH}$ range of 2 to approximately 11. Above $\mathrm{pH} 11, \mathrm{AmO}_{2}$ is again the most stable precipitate. For the conditions considered here, $\mathrm{AmPO}_{4}(\mathrm{am})$ is much less soluble than the $\mathrm{AmOHCO}_{3} \cdot 0.5 \mathrm{H}_{2} \mathrm{O}(\mathrm{cr})$ phase, maintaining americium concentrations at much lower values. 


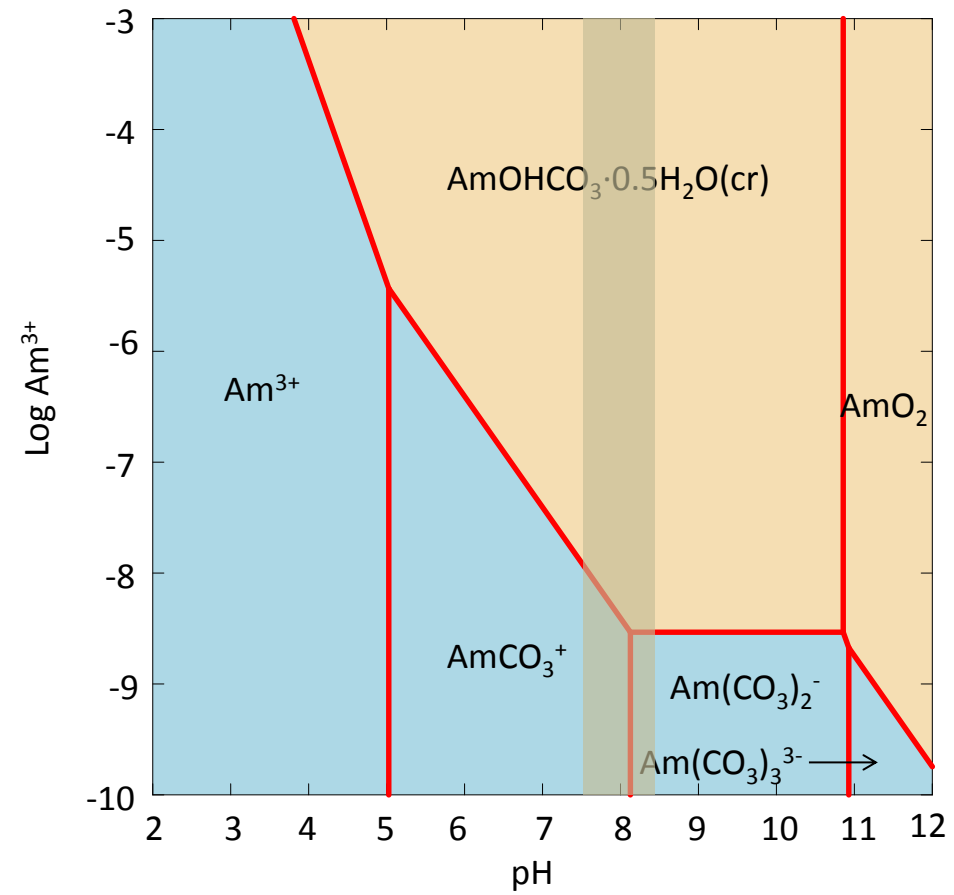

Figure 4.7. Solubility of Americium Phases in a Hypothetical Hanford Site Groundwater with a Composition of $2 \times 10^{-3} \mathrm{M} \mathrm{HCO}_{3}^{-}, 10^{-3} \mathrm{M} \mathrm{Cl}^{-}, 5 \times 10^{-4} \mathrm{M} \mathrm{SO}_{4}{ }^{2-}, 10^{-3} \mathrm{M} \mathrm{Na}^{+}$, $2 \times 10^{-3} \mathrm{M} \mathrm{Ca}^{2+}$, and $5 \times 10^{-4} \mathrm{M} \mathrm{Mg}^{2+}(298.15 \mathrm{~K}, 0.1 \mathrm{Mpa})$, Shaded Area Indicates Approximate Range of Uncontaminated Hanford Groundwater and Pore Water

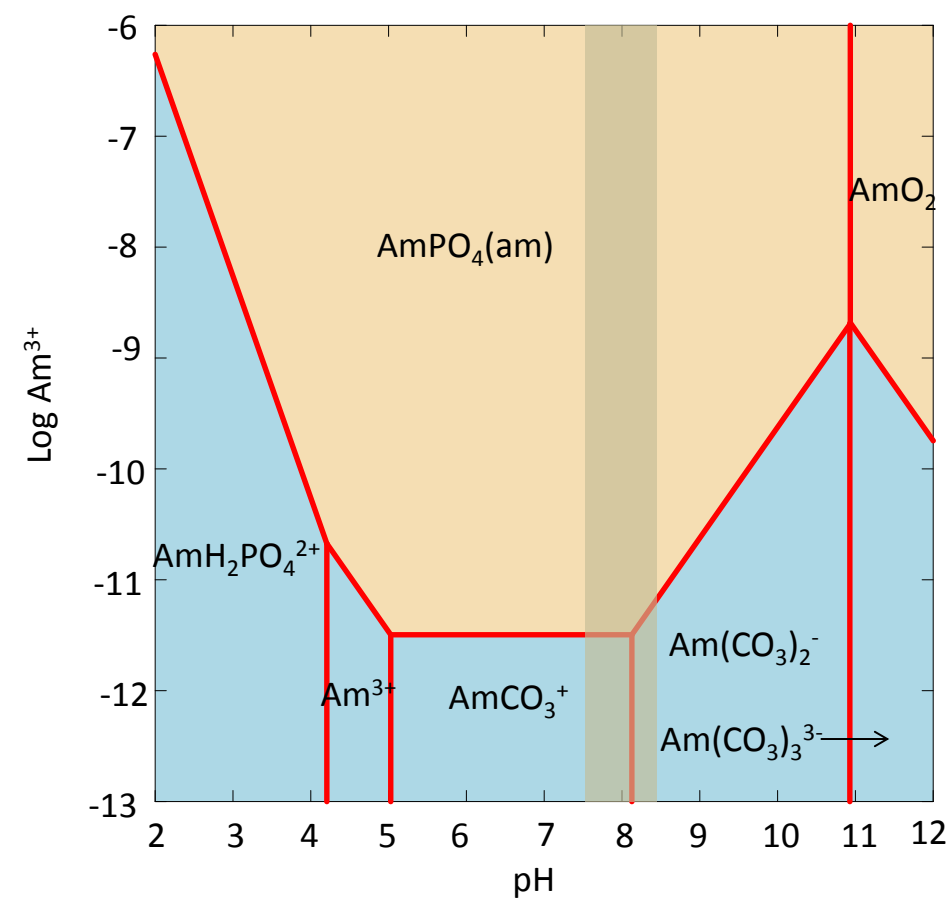

Figure 4.8. Solubility of Americium Phases in a Hypothetical Hanford Site Groundwater with a Composition of: $2 \times 10^{-3} \mathrm{M} \mathrm{HCO}_{3}^{-}, 10^{-3} \mathrm{M} \mathrm{Cl}^{-}, 5 \times 10^{-4} \mathrm{M} \mathrm{SO}_{4}{ }^{2-}, 10^{-6} \mathrm{M} \mathrm{HPO}_{4}{ }^{2-}$, $10^{-3} \mathrm{M} \mathrm{Na}^{+}, 2 \times 10^{-3} \mathrm{M} \mathrm{Ca}^{2+}$, and $5 \times 10^{-4} \mathrm{M} \mathrm{Mg}^{2+}(298.15 \mathrm{~K}, 0.1 \mathrm{Mpa})$, Shaded Area Indicates Approximate Range of Uncontaminated Hanford Groundwater and Pore Water 


\subsection{Organo-Phosphates and Phosphonates and Implications for Plutonium and Americium Mobility}

As indicated in Chapters 2 and 3, several waste sites (216-Z-18, 216-Z-1A, and 216-Z-9) where high quantities of plutonium were disposed, large quantities of acid/organic rich wastes were co-disposed. The major components of these organic wastes were derived from organic phase solvent extraction streams which consisted of carbon tetrachloride, TBP, and DBBP. During the plutonium recovery process TBP undergoes both thermal decomposition and radiolysis to generate DBP, monobutyl phosphate (MBP), and butanol (Grant et al. 1997). Hence, these breakdown products need to be considered as part of the waste stream along with the other solvents. TBP, DBP, MBP, and DBBP are well known to form neutral complexes with plutonium and nitrate that extract into the organic phase (see the review by Cleveland 1979). DBP and possibly MBP can also form both aqueous complexes with plutonium and americium and/or solid phase precipitates (Cleveland 1979; Pasquiou et al. 1987). Carbon tetrachloride as an organic phase, which has a higher density than aqueous solutions in which it is co-disposed, also has the potential to migrate along with aqueous solutions in the Hanford Site subsurface (see Oostrom et al. 2007; White et al. 2008). These factors suggest that co-disposed organic solvents or complexing agents could impact the subsurface transport of plutonium and americium in both aqueous solutions and in any DNAPLs that may have moved through the subsurface (Felmy et al. 2010).

\subsubsection{Aqueous Phase Transport}

Transport of plutonium and americium in the aqueous phase can be impacted by the potential formation of aqueous complexes or solid phases with TBP, DBBP, or their breakdown products. For example, thermodynamic data for a Pu(IV)-DBP precipitate are reported by Pasquiou et al. (1987). They report solubility products for two possible compositions of $\mathrm{Pu}(\mathrm{IV})$-DBP precipitates, i.e. $\mathrm{Pu}(\mathrm{DBP})_{4}$ with $\log \mathrm{K}_{\mathrm{sp}}=-27$ and $\mathrm{Pu}\left(\mathrm{NO}_{3}\right)_{2}(\mathrm{DBP})_{2} \cdot 2 \mathrm{H}_{2} \mathrm{O}$ with $\log \mathrm{K}_{\mathrm{sp}}=-16$. For Am(III)-DBP precipitates, there are only four data points determined in $3 \mathrm{M} \mathrm{HNO}_{3}$ on the solubility of $\mathrm{Am}(\mathrm{DBP})_{3}$ (Bogdanov et al. 1979. However, the solubility of lanthanide(III)-DBP phases (possible analogs for Am(III) phases) is reported by Sheka and Sinyavskaya $(1964 a, b)$. They report a solubility product for $\operatorname{La}(\mathrm{DBP})_{3}$ of $\log \mathrm{K}_{\mathrm{sp}}=-9.5$. These results imply that for solutions containing DBP there is little potential for DBP complexes to increase the solubility of plutonium and americium in the aqueous phase. In the development of the PUREX process and other solvent extraction processes for plutonium, a great deal of research was done on the impact of TBP, DBP, and other complexants on the solvent extraction properties of plutonium and other actinides with an emphasis on the species that were formed in the organic solvents (see the review in Cleveland 1979). However, the neutral TBP and DBBP coordination complexes that form with plutonium and americium, being non-ionic, are not likely to be stable in aqueous solutions. The structure of uncomplexed TBP and DBP in both aqueous solutions and organic solvents has been studied by phosphorus-31 nuclear magnetic resonance (NMR) spectroscopy (Belaid and Chachaty 1982; Uetake 1991; Iida and Hata 1992). Although it is known that the free hydroxyl groups in the structures of DBP and MBP could potentially form ionic complexes, very little information is available on the formation of such aqueous complexes. Sheka and Sinyavskaya (1964b) do report a stability constant for a LaDBP ${ }^{2+}$ complex of $\log K=1.78$. Such a value implies a limited stability for aqueous Am-DBP complexes. More recently, Zhang and Kimura (2006) have used highly sensitive laser luminescence techniques to examine $\mathrm{Eu}(\mathrm{III})$-DBP complexes, although once again the emphasis of that study was on identification of the extracted complexes in the organic phase. Although the research is certainly limited, the information that is available indicates that the organic breakdown products of TBP tend to form insoluble solids with 
actinides in the IV and III oxidation states in preference to aqueous complexes. This is a likely result of the presence of the hydrophobic butyl groups on both TBP and MBP. These results suggest that transport of plutonium and americium in the aqueous phase by complexes with TBP, DBBP, or their breakdown products will not be important.

\subsubsection{Organic Phase (DNAPL) Transport}

As noted previously, large quantities of organic solvents were co-disposed along with acidic plutonium and americium containing solutions at selected waste sites. For example, Oostrom et al. (2007) report that the three major disposal facilities that received organic rich wastes received between 363,000 and 580,000 liters of carbon tetrachloride, the majority of which migrated in the subsurface as an organic liquid (DNAPL). Although the concentration of DNAPL gradually reduced with time resulting from adsorption to the soil or dissolution into the soil gas or aqueous solution, model calculations indicate that even in 1993 approximately $43 \%$ of the of the original DNAPL inventory was still present in the vadose zone. In at least partial support of this, Bowles and Rohay (2007) report the development of a fleeting magenta color after the addition of iodine solution to sediments from a soil sample 52.5 to $54.5 \mathrm{ft}$ downhole in a core from Well 299-W15-48 collected beneath the 216-Z-9 disposal site. The development of a magenta color is indicative of the possible presence of carbon tetrachloride as a DNAPL (see Bowles and Rohay 2007).

If carbon tetrachloride is transported in the subsurface as a DNAPL then the possibility exists that plutonium or americium could be complexed with the extraction agents (e.g., TBP or DBP) and transported as a neutral complex within the organic phase. Previous researchers (Scoazec et al. 1990) have also shown that even plutonium polymers can be extracted by acidic DBP solutions into the organic phase and recently Tkac and Paulenova (2010) have also shown that $\mathrm{Pu}(\mathrm{IV})$ colloids can be extracted from acidic TBP solutions (0.1-10 M nitric acid). In addition, Solovkin and Lobanov (1990) have shown that at lower acidity $\mathrm{Pu}(\mathrm{IV})$ was concentrated at the organic/solution interface in the presence of DBP at least when the organic phase was n-decane. However, the results for carbon tetrachloride as an organic solvent were less clear. Cleveland (1979) also points out that DBP and MBP are deleterious to TBP extraction since DBP and MBP can form precipitates with metal ions that concentrate at liquid interfaces making phase separation difficult. Previous subsurface research at the 216-Z-9 disposal site, discussed in Section 3, has indicated that high concentrations of plutonium, americium, and TBP occur at and above the bottom of a silt layer located $65 \mathrm{ft}$ bgs, indicating that plutonium migrated with organic co-contaminants during the operational period. Hence, the possible role of organic solvents in the past transport of plutonium and americium at sites in which they were co-disposed is still unclear.

\subsubsection{Biodegradation}

The degradation of TBP to inorganic phosphate has important implications regarding plutonium and americium mobility at Hanford waste sites where acidic/organic rich wastes were co-disposed due to the low solubility of plutonium and americium phosphates. In this regard, Thomas and Macaskie (1998) investigated the effect of some environmental and physiological constraints on biodegradation of tributyl phosphate by a mixed microbial culture. It was determined that phosphate was released at concentrations that were high enough to precipitate uranium locally from solution. In addition to TBP biodegradation rates, Thomas and Macaskie (1998) also determined that DBP biodegradation was nearly $50 \%$ faster than that of TBP. A number of factors affected or inhibited the rate of TBP biodegradation. Biodegradation 
was optimal at $30^{\circ} \mathrm{C}$, reduced at $20^{\circ} \mathrm{C}$ and negligible at $4{ }^{\circ} \mathrm{C}$ and $37^{\circ} \mathrm{C}$. Significantly, growth of the bacteria at the expense of TBP as a carbon and phosphorus source occurred over a $\mathrm{pH}$ range from 6.5 to 8 , and optimally at $\mathrm{pH}$ 7. For Hanford waste sites that received high salt, acidic, organic type wastes, biodegradation is not expected to be significant due to the low $\mathrm{pH}$ conditions prevalent at locations where significant concentrations of plutonium, americium, and TBP occur.

\subsection{Importance of Precipitation and Mass-Transfer Processes}

The precipitation of plutonium and americium in Hanford Site sediments is linked to the concentrations in the disposed solutions, the oxidation state (plutonium), the acidity or $\mathrm{pH}$ of the discharged solutions, the presence of ligands (such as $\mathrm{PO}_{4}$ ) that can form solid phases, and the changes in chemistry that can occur when the waste solutions contact the subsurface sediments. In this regard, the acidic wastes discharged to the 216-Z-9 Trench, the 216-Z-1A Tile Field, and the 216-Z-18 Crib are examples of disposal sites where precipitation of plutonium, and possibly americium, solids would occur as the acid waste solutions contact the underlying sediments (Ames 1974; Price and Ames 1975; Price et al. 1979). The precipitation of this "non-particulate plutonium" appears to be linked with the dissolution of basic minerals (such as carbonates or feldspars) present in the sediments which can create higher $\mathrm{pH}$ regions in the local chemical environments near the mineral surfaces. Earlier reports (Ames 1974; Price et al. 1979) indicated that the chemical form of the precipitated plutonium was most likely plutonium polymer or amorphous plutonium hydroxide. However, recent analysis of the 216-Z-9 Trench near surface sediments by Batuk et al. (2012) and Buck et al. (2012) (see Section 6) indicates that a significant fraction of the precipitated plutonium could have occurred as plutonium phosphates or plutonium phosphates/silicates. The source of the phosphate in the waste solution is not precisely known, but thermal, radiolytic, and microbial breakdown of TBP or DBP are likely (see Section 4.3).

Interestingly, as noted earlier in this section, plutonium can form insoluble phosphate compounds in both oxidations states (III) and (IV) [e.g., $\mathrm{PuPO}_{4}, \mathrm{Pu}\left(\mathrm{HPO}_{4}\right)_{2}$ ]. Hence, even if reducing conditions occurred in the surface sediments (as a result of radiolytic production of $\mathrm{H}_{2}(\mathrm{~g})$ or organic reduction) the precipitation of plutonium as phosphate compounds should have continued to maintain low solubilities. The possible reasons for the apparent association of plutonium with silica is also unknown since no thermodynamic data for plutonium-silicate solids have been reported (see Guillaumont et al. 2003). The corresponding $\mathrm{U}(\mathrm{IV})$ phase (i.e., coffinite $\mathrm{USiO}_{4}$ ) is well known in uranium ore deposits as an alteration product of uraninite (Pointeau et al. 2009), although the temperature of formation of coffinite in sedimentary rocks is generally believed to be high $\left(80^{\circ} \mathrm{C}-140^{\circ} \mathrm{C}\right)$ (Deditius et al. 2008). Recent evidence also support the association of U(IV) with silica colloids (Dreissig et al. 2011). However, it is also possible that the apparent plutonium-silica association results from the fact that silica solubility is low under acid conditions even as amorphous silica. Hence, the plutonium-silica association may simply result from the silica being left behind as the aluminum or calcium components of the feldspars or other minerals dissolves. Clearly, more research is needed on the observed formation of plutonium phosphates/silicates in Hanford Site sediments.

Precipitation of plutonium compounds at disposal sites that did not receive acid waste is less clear owing to the fact that $\mathrm{Pu}(\mathrm{IV})$ is insoluble as $\mathrm{PuO}_{2}$ under circumneutral $\mathrm{pH}$ values. Hence, for plutonium to precipitate from such solutions would require that plutonium to have occurred in oxidation states other than $\mathrm{Pu}(\mathrm{IV})$ in the disposed waste [i.e., $\mathrm{Pu}(\mathrm{V})$ or $\mathrm{Pu}(\mathrm{III})]$. Unfortunately, the oxidation state of the plutonium in the disposed wastes is uncertain. 
The possibility of americium precipitation in Hanford Site sediments has never been established. In general, Am(III) is soluble over a wide range of $\mathrm{pH}$ values in the absence of other ligands. However, in the presence of phosphate, americium forms highly insoluble $\mathrm{AmPO}_{4}$ analogous to $\mathrm{PuPO}_{4}$. Hence, the precipitation of $\mathrm{AmPO}_{4}$ or the substitution of americium into plutonium phosphate compounds could have occurred at acid waste disposal sites. However, no evidence of such formation reactions currently exists. Americium can also form insoluble americium carbonate compounds, such as $\mathrm{AmOHCO}_{3}$, at circumneutral $\mathrm{pH}$ values but again no evidence for the formation of such compounds in Hanford Site sediments exits. 


\subsection{Adsorption and Surface Complexation}

Traditionally, when metal concentrations are calculated to be below the solubility limits of solubility controlling phases, adsorption has been defined as the primary mechanism controlling solution concentrations and migration in the vadose zone and groundwater. Typically adsorption to solid surfaces will immobilize metals from the aqueous phase; however, adsorption to surface sites on mobile colloidal particles can potentially act as a transport vector under certain circumstances. The focus of this section will be adsorption to immobile mineral and amorphous surfaces that can occur within the sediment matrix. The influence of colloids on the transport of plutonium and americium will be addressed in Chapter 6.0.

Adsorption of metals to soils, sediments, and minerals has been modeled using a variety of approaches that range from simple empirical approaches to mechanistically based surface complexation models. Empirical approaches include the linear distribution coefficient $\left(\mathrm{K}_{\mathrm{d}}\right)$ model, and the Freundlich and Langmuir isotherm equations. Empirical approaches are not capable of accounting for the effects of variable chemical conditions on adsorption reactions. In contrast, surface complexation models are capable of accounting for the impact of variable chemical conditions on absorption. These surface complexation models define specific surface species, chemical reactions, equilibrium constants, mass balances, and charge balances. These molecular features of surface complexation models give them a thermodynamic basis. A detailed account of approaches to modeling metal adsorption can be found in Goldberg et al. (2007).

Ion adsorption mechanisms and surface configurations of adsorbed species can be determined from independent experimental observations and can provide mechanistic validation for surface complexation models. Experimental techniques used to corroborate mechanistic hypotheses can include both indirect measurements, such as point of zero charge shifts, ionic strength effects, and calorimetry, and direct spectroscopic techniques, including vibrational spectroscopy, NMR spectroscopy, and x-ray absorption spectroscopy.

Surface complexation models were initially developed for single (pure) mineral phases but have now been applied to natural mineral assemblages such as sediments and soils using both component additivity and generalized composite approaches (Davis et al. 2005, 2002, 1998; Honeyman 1984; Payne et al. 2004; Waite et al. 2000). Surface complexation models have been used in subsurface transport models at several field sites; however, simplifying assumptions are required to handle heterogeneous materials (e.g., Curtis et al. 2006; Stollenwerk 1998; Kent et al. 2000).

In general terms, sorption of plutonium in the $\mathrm{Pu}(\mathrm{III})$ and $\mathrm{Pu}(\mathrm{IV})$ oxidations states is stronger than the dioxo $\mathrm{Pu}(\mathrm{V})$ and $\mathrm{Pu}(\mathrm{VI})$ oxidation states (Choppin 2007). In addition, many studies indicate that $\mathrm{Pu}(\mathrm{V})$ reduces to the more insoluble $\mathrm{Pu}(\mathrm{IV})$ on the surfaces of a variety of minerals and sediments (KenneyKennicutt and Morse 1985; Powell et al. 2005; Shaughnessy et al. 2003; Kaplan et al 2004; Kalmykov et al. 2007). However, owing to the low solubility of $\mathrm{Pu}(\mathrm{IV})$ compounds determining the precise nature of what is, or can be defined as, a Pu(IV) adsorbed species has been a difficult challenge. Traditionally, as noted above, such a distinction has been primarily determined either by direct identification of a specific $\mathrm{Pu}(\mathrm{IV})$ solid phase or, more commonly, by thermodynamic calculations that indicate the saturation state of the solution with respect to a solid precipitate. However, with the recent advances in analytical methods, primarily XAFS spectroscopy, it is becoming increasingly possible to more precisely 
determine what should be treated as an actinide adsorbed species or as a discrete solid phase, even for highly insoluble tetravalent actinides. For example, very recently, Veeramani et al. (2011) were able to distinguish the difference between a U(IV) adsorbed phosphate complex from a distinct U(IV) phosphate precipitate primarily by the absence of a long-range U(IV)-U(IV) backscatter in their XAFS spectra. The absence of such a backscatter indicated the presence of "monomeric" U(IV) which is indicative of the presence of adsorbed species rather than a discrete uranium solid phase with long-range order. Similarly, analysis of plutonium-contaminated 216-Z-12 sediments from the Hanford Site by XAFS spectroscopy also showed a lack of a $\mathrm{Pu}(\mathrm{IV})-\mathrm{Pu}(\mathrm{IV})$ backscatter (Felmy et al. 2010). This indicates that the $\mathrm{Pu}(\mathrm{IV}$ ) present at the 216-Z-12 disposal site is probably best represented as an adsorbed complex, rather than as a distinct plutonium solid phase, which is more characteristic of the plutonium disposed at the 216-Z-9 site (see Section 3). It should also be possible to identify co-adsorbed or co-precipitated species with tetravalent actinides using XAFS spectroscopy, as has been done by Boyanov et al. (2007) in identifying U(IV)-Fe associations. Although, to the best of our knowledge, such methods have not been applied to identify specific $\mathrm{Pu}(\mathrm{IV})$-metal ion associations in complex natural materials such as soils or sediments.

\subsection{Hanford-Specific Plutonium and Americium Distribution Coefficient Data}

Plutonium and americium (both free cations and many aqueous complexes) readily partition to natural materials such as sediments, soils, and minerals under most natural conditions (EPA 1999, 2004). A compilation of $\mathrm{K}_{\mathrm{d}}$ values measured using various Hanford Site sediments and various solution compositions is available (Cantrell et al. 2003). Results from these data for plutonium and americium are summarized as follows.

Delegard and Barney (1983) conducted a series of plutonium adsorption experiments on Hanford Site sediment at high base concentrations and variable concentrations of chelating agents. It was found that even at high base concentrations, plutonium adsorption was moderately high. A combination of high base and high ethylenediaminetetraacetic acid (EDTA) concentrations reduced plutonium adsorption the most; however, even under these conditions significant adsorption occurred. $\mathrm{K}_{\mathrm{d}}$ measurements conducted using high salt-acid waste indicated that plutonium adsorption was low $\left(\mathrm{K}_{\mathrm{d}}<1 \mathrm{~mL} / \mathrm{g}\right)$ (Hajek and Knoll 1966). In another study in which $\mathrm{K}_{\mathrm{d}}$ values for plutonium were measured on Hanford Site sediment at different solution to solid ratios, variable initial plutonium concentrations and a range of $\mathrm{pH}$ values from 0.5 to 14 , it was determined that plutonium adsorption was high, except at very low $\mathrm{pH}$ (Rhodes 1952, 1957). The results of Rhodes $(1952,1957)$ at low and high $\mathrm{pH}$ are inconsistent with the Hajek and Knoll (1966) results. It is possible that the high $\mathrm{K}_{\mathrm{d}}$ values determined by Rhodes resulted from precipitation as a result of the high initial plutonium [stated to be $\mathrm{Pu}(\mathrm{IV})$ ] concentrations used in the experiments.

$\mathrm{K}_{\mathrm{d}}$ values for Am(III) measured under conditions that closely approximate those of natural Hanford Site groundwater indicate that Am(III) $\mathrm{K}_{\mathrm{d}}$ values are high (>1200 mL/g) (Routson et al. 1975, 1976). $\mathrm{Am}$ (III) $\mathrm{K}_{\mathrm{d}}$ values measured under highly basic $\mathrm{pH}$ conditions (1 $\mathrm{M}$ and $4 \mathrm{M} \mathrm{NaOH}$ ) were also determined to be large (Delegard and Barney 1983); however, it is not clear if the high Am(III) $\mathrm{K}_{\mathrm{d}}$ values measured were the result of adsorption or a combination of adsorption and precipitation. When high concentrations of EDTA are present $(0.05$ to $0.15 \mathrm{M})$ along with the base, Am(III) $\mathrm{K}_{\mathrm{d}}$ values are significantly reduced to low or moderate values. Am(III) $\mathrm{K}_{\mathrm{d}}$ values measured under high salt acidic conditions $(\mathrm{pH}<3)$ are low $(<1 \mathrm{~mL} / \mathrm{g})$ (Hajek and Knoll 1966). 
Tables with recommended $\mathrm{K}_{\mathrm{d}}$ values developed for various waste site chemistry categories, relative impact zones, and sediment textures are available in Last et al. (2006). Use of these data can be beneficial when used appropriately, such as for screening calculations in the absence of more site-specific data. However, these generic $K_{d}$ values should be used with caution. Improper application of generic $K_{d}$ values can result in erroneous predictions. This is particularly true for situations such as waste sites with high spatial variability in chemical conditions or where precipitation rather than adsorption is the dominant mechanism controlling solution concentrations.

\subsection{Surface Complexation of Plutonium}

Although no plutonium or americium surface complexation studies for Hanford sediments are currently available, a number of studies have been published on plutonium adsorption onto various mineral surfaces that occur in Hanford sediments (e.g., Sanchez et al. 1985; Lu et al. 2003; Hixon et al 2010; Romanchuk et al. 2011; Keeney-Kennicutt and Morse 1985; Powell et al. 2005; Fjeld et al. 2003). Recently new surface complexation models were developed to describe equilibrium and rate-limited sorption and desorption of plutonium on and off of iron oxide (geothite) and silica surfaces (Schwantes and Santschi 2010). The model was developed using a generic approach to estimate sorption constants that required minimal laboratory calibrations. The model consists of six equilibrium surface reaction equations and one kinetic equation (Table 5.1). The constants for the first four reactions, describing adsorption of free and linear dioxocations for each plutonium oxidation state, were derived from an empirical relationship described previously (Wang et al. 2001; Schwantes 2004). Constants for the last two reactions involving hydrolyzed species of $\mathrm{Pu}^{4+}$ were generated using an empirical relationship presented in Schwantes and Santschi (2010). The kinetic model that describes rate-limited sorption and desorption, decouples reduced (III, IV) and oxidized (V, VI) forms of plutonium using a single ratelimiting, but reversible, surface mediated reaction.

Table 5.1. Surface Complexation Model for Plutonium Adsorption onto Geothite and Silica (298.15 K, $0.1 \mathrm{Mpa}$ ) (Schwantes and Santschi 2010)

\begin{tabular}{|c|c|c|}
\hline Reaction & Log K (Goethite) & Log K (Silica) \\
\hline$\equiv \mathrm{SOH}+\mathrm{Pu}^{3+} \leftrightarrow \equiv \mathrm{SOPu}^{2+}+\mathrm{H}^{+}$ & -2.1 & -10 \\
\hline$\equiv \mathrm{SOH}+\mathrm{Pu}^{4+} \leftrightarrow \equiv \mathrm{SOPu}^{3+}+\mathrm{H}^{+}$ & 15.3 & 7.2 \\
\hline$\equiv \mathrm{SOH}+\mathrm{PuO}_{2}^{+} \leftrightarrow \equiv \mathrm{SOPuO}_{2}+\mathrm{H}^{+}$ & -8.5 & -16.5 \\
\hline$\equiv \mathrm{SOH}+\mathrm{PuO}_{2}^{2+} \leftrightarrow \equiv \mathrm{SOPuO}_{2}^{+}+\mathrm{H}^{+}$ & 1.2 & -6.5 \\
\hline$\equiv \mathrm{SOH}+\mathrm{Pu}^{4+}+3 \mathrm{H}_{2} \mathrm{O} \leftrightarrow \equiv \mathrm{SOPu}(\mathrm{OH})_{3}+4 \mathrm{H}^{+}$ & 12.5 & 4.6 \\
\hline$\equiv \mathrm{SOH}+\mathrm{Pu}^{4+}+4 \mathrm{H}_{2} \mathrm{O} \leftrightarrow \equiv \mathrm{SOPu}(\mathrm{OH})_{4}{ }^{-}+5 \mathrm{H}^{+}$ & 5.0 & -2.3 \\
\hline$\equiv \mathrm{SOPuO}_{2}+\mathrm{H}_{2} \mathrm{O}+1 / 2 \mathrm{H}_{2(\mathrm{~g})} \stackrel{\mathbf{k}_{\mathbf{1}}}{\underset{\mathbf{k}_{2}}{\rightleftarrows}} \equiv \mathrm{SOPu}(\mathrm{OH})_{3}$ & \multicolumn{2}{|c|}{$\log k_{1}=-5.3$} \\
\hline$-\mathrm{d}\left[\equiv \mathrm{SOPuO}_{2}\right] / \mathrm{dt}=\mathrm{k}_{1}\left[\mathrm{Pu}_{\mathrm{ox}}\right]-\mathrm{k}_{2}\left[\mathrm{Pu}_{\mathrm{red}}\right]^{(\mathrm{a})}$ & & \\
\hline
\end{tabular}

(a) $\left[\mathrm{Pu}_{\mathrm{ox}}\right]$ is sum of oxidized ( $\mathrm{V}$ and $\left.\mathrm{VI}\right)$ surface species and $\left[\mathrm{Pu}_{\mathrm{red}}\right]$ is sum of the reduced species (III and IV) surface species. 
The predictive capability of the equilibrium and kinetic models was validated using previously published experimental results and support the mechanisms used in the model to describe sorption of plutonium on the two mineral oxide surfaces. The existence of the six assumed sorbing species, $\equiv \mathrm{SOPu}^{2+}$, $\equiv \mathrm{SOPu}^{3+}, \equiv \mathrm{SOPuO}_{2}, \equiv \mathrm{SOPuO}_{2}{ }^{+}, \equiv \mathrm{SOPu}(\mathrm{OH})_{3}$, and $\equiv \mathrm{SOPu}(\mathrm{OH})_{4}{ }^{-}$, were not confirmed, but are justified based on theoretical considerations (Schwantes and Santschi 2010). The model does not account for the impact of $\mathrm{PuO}_{2}{ }^{2+}$ carbonate surface species, which are potentially important at higher $\mathrm{pH}$ values (Murphy et al. 1999).

Based on simulation results determined with this conceptual adsorption model, several significant implications were put forth by Schwantes and Santschi (2010).

1. Under most conditions, surface species of the IV and VI oxidation states dictate overall sorption behavior of the element.

2. Rate limitations during the sorption process are only expected when the initial forms of plutonium are that of oxidized (V and/or VI) species.

3. Sorption kinetics for plutonium may be most important for mineral surfaces (like goethite) that have high affinity for the element.

In addition, the desorption reaction rate that was determined is orders of magnitude faster than previous estimates. Much slower reaction rates have been estimated by assuming that oxidized forms of plutonium initially dominating solution speciation will govern speciation on the mineral oxide surfaces over time (Guillaumont et al. 2003; Lu et al. 2003; Painter et al. 2002). Based on these assumptions, it has been suggested that adsorption of oxidized species may be irreversible. As a result, model predictions based on these assumptions have severely overestimated the kinetic stability of plutonium sorbed species and the impact plutonium sorption kinetics has on pseudocolloid transport mechanisms (Painter et al. 2002).

In another study, Romanchk et al. (2011) examined plutonium adsorption onto hematite at femto- and nanomolar concentrations. In this study, it was demonstrated that at low concentration $\left(\sim 10^{-14} \mathrm{M}\right) \mathrm{Pu}(\mathrm{IV})$ adsorption was fast, whereas $\mathrm{Pu}(\mathrm{VI})$ adsorption was kinetically controlled by slow reduction to $\mathrm{Pu}(\mathrm{IV})$ on the surface. This is consistent with the kinetic model developed by Schwantes and Santschi (2010) and is not consistent with $\mathrm{Pu}(\mathrm{V})$ disproportionation on the surface or self-reduction due to radiolysis. Romanchk et al. (2011) also proposed that at higher plutonium concentrations $\left(\sim 10^{-9} \mathrm{M}\right) \mathrm{Pu}(\mathrm{IV})$ polymerizes on the surface based on the sorption kinetics and desorption behavior.

Lujaniene et al. (2010) developed a surface complexation model for plutonium and americium adsorption onto a natural Triassic clay. The clay used in this study was composed of microaggregates of clay particles [with $56 \%-71 \%$ of smectite, including $14 \%$ of montmorillonite, $20 \%$ of illite, and from $1 \%$ to $9 \%$ of chlorite minerals (wt. basis)] which were cemented by limonite $\mathrm{FeO}(\mathrm{OH}) \cdot \mathrm{nH}_{2} \mathrm{O}$. Two samples of the clay were used for the sorption studies: sample $\mathrm{S}(1)$ contained siderite $\left(\mathrm{FeCO}_{3} 1.6 \%\right)$, hematite $\left(\mathrm{a}-\mathrm{Fe}_{2} \mathrm{O}_{3} 2.3 \%\right)$, goethite (a-FeOOH $\left.0.1 \%\right)$, calcite $\left(\mathrm{CaCO}_{3} 19.8 \%\right)$, and total organic carbon (TOC $0.034 \%$ ) in surface coatings. Sample $\mathrm{S}(2)$, originally $\mathrm{S}(1)$ from which surface coatings containing carbonates and iron oxides were removed by leaching with $2 \mathrm{~mol} / \mathrm{L} \mathrm{HCl}$ and then by citrate-dithionite treatment. The background electrolyte consisted of 0.01 or $0.1 \mathrm{M} \mathrm{NaNO}_{3}$.

Experimental results of Lujaniene et al. (2010) indicated that plutonium sorption to the natural clay was strong in the studied $\mathrm{pH}$ range of 3.5 to 8.5 . Based on surface speciation calculations, it was 
suggested that at low $\mathrm{pH}$ (3.5 to 6) plutonium adsorption was dominated by ion exchange on layer sites. At higher $\mathrm{pH}$, sorption to edge sites also occurred. Sorption and speciation of plutonium was not affected by ionic strength (between 0.01 and $0.1 \mathrm{M}$ ). Comparison of the experimental results with surface speciation calculations indicated that at low $\mathrm{pH}(<4-5)$ and high $\mathrm{pH}(>8$ for goethite) mineral coatings (goethite, hematite, and magnetite) played a minor role in plutonium adsorption to the natural clay. Lujaniene et al. (2010) also indicated that other mineral coatings (ferrihydrite and organic matter) could enhance plutonium uptake on the clay particles.

\subsection{Surface Complexation of Americium}

Surface complexation models have been developed or used to model americium adsorption for various mineral phases in several studies (Degueldre et al. 1994; Alonso and Degueldre 2003; Lujaniene et al. 2010). Degueldre et al. (1994) studied sorption of americium on montmorillonite, illite, and hematite colloids. In this study, the role of particle and carbonate concentration was investigated. Distribution coefficients were found to be independent of colloid concentration in the range of 1 to 300 parts per million ( $\mathrm{ppm}$ ), indicating that significant colloid aggregation did not take place. It was also determined that formation of carbonate and hydroxide-carbonate complexes in solution compete with surface complexes. Based on their analyses, they concluded that in addition to free americium $\left(\mathrm{Am}^{3+}\right)$, hydroxide, carbonate, and mixed hydroxide-carbonate complexes were sorbed to the colloids. A relatively simple surface complexation model was established that described the experimental sorption data.

In a later work, Alonso and Degueldre (2003) studied sorption of americium on $\mathrm{Al}_{2} \mathrm{O}_{3}, \mathrm{FeOOH}$, and $\mathrm{SiO}_{2}$ colloids under variable $\mathrm{pH}$, redox potential (Eh), and carbonate concentration. As expected, Eh under environmentally relevant conditions did not influence adsorption of americium. An equation was developed for the americium $\mathrm{K}_{\mathrm{d}}$ that accounted for cation exchange, surface complexation with one type of surface site, and solution complexation. Americium sorption on the colloids followed the order $\mathrm{Al}_{2} \mathrm{O}_{3}$ $>\mathrm{FeOOH} \gg>\mathrm{SiO}_{2}$. In the absence of carbonate, maximum adsorption occurred at approximately $\mathrm{pH} 8$ for $\mathrm{Al}_{2} \mathrm{O}_{3}, \mathrm{pH} 10$ for $\mathrm{FeOOH}$, and $\mathrm{pH} 7$ for $\mathrm{SiO}_{2}$. At a solution concentration of $0.02 \mathrm{M}$, carbonate significantly reduced sorption for all three colloids was observed over the $\mathrm{pH}$ range of 6 to 12 .

As indicated in Section 5.2, Lujaniene et al. (2010) developed a surface complexation model for plutonium and americium adsorption onto a natural Triassic clay. For americium, sorption was dominated by ion exchange on layer sites. The predominate sorbing species were $\mathrm{Am}^{3+}$ and $\mathrm{AmNO}_{3}{ }^{2+}$, with $\mathrm{Am}^{3+}$ being dominant at higher $\mathrm{pH}$ values $(\mathrm{pH}>4)$. Surface speciation was affected by ionic strength and corresponded with changes in solution speciation.

\subsection{Summary and Implications}

When plutonium and americium concentrations are below the solubility limits of applicable solubility controlling phases, adsorption to mineral surfaces can be important. Adsorption is particularly important in the far field region of a waste site. The degree of adsorption can vary considerably and is dependent upon oxidation state (for plutonium), $\mathrm{pH}$, complexation with dissolved ligands, and mineral surface type and surface area. Some of the more important minerals that can adsorb plutonium and americium include various metal oxides (iron oxides, manganese oxides, aluminum oxides), clay minerals, calcite, and silica. All of these minerals occur in Hanford sediments. Of these minerals, the most significant for adsorption 
of plutonium and americium on Hanford sediments are likely to be iron oxides, clay minerals, and calcite; however, this will be very dependent upon their concentrations in the sediment and will therefore be site specific. 


\subsection{Plutonium and Americium Colloids}

According to International Union of Pure and Applied Chemistry (IUPAC), colloids are nanoparticles and macromolecules in the defined size range between $1 \mathrm{~nm}$ to $1 \mu \mathrm{m}$ (Buffle and van Leeuwen 1992). Colloids are complex particles that are suspended in solutions and are a potentially important means of transport of actinides in environmental systems. There are two types of colloids that are important with respect to the transport of actinides in aquatic environments. These are referred to here as intrinsic colloids and pseudo colloids. Intrinsic colloids (sometimes called real, pure, or true colloids) are primarily composed of actinides formed through condensation by hydrolytic or precipitation processes. Pseudo colloids (or associative colloids) are colloids in which trace amounts of actinides adsorb to naturally occurring colloids that consist of various minerals, clays and oxides, partially coated with organic matter, and organic macromolecules. Colloidal particles are generated through physical fragmentation, erosion, and nucleation and precipitation from oversaturated solutions and can be removed from solution by coagulation, attachment and settling, and dissolution. Because colloids are complex species, they must be characterized in detail to provide the data to reduce uncertainty in larger-scale transport models. Unfortunately, colloid characterization is difficult because of their small sizes, chemical complexity, and structural variability. A single colloid may be a composite of irregular structures with differing compositions which further complicates characterization.

Colloid characterization techniques include imaging and surface probing techniques, dynamic size determination, and chemical and structural characterization (Wilkinson and Lead 2007). Imaging and surface probing techniques include transmission electron microscopy (TEM) which if coupled with x-ray energy dispersive spectroscopy or other techniques can also give chemical information on the particles (Powell et al. 2011), atomic force microscopy techniques for imaging, measuring adhesion forces, and charge distributions. Dynamic size determination techniques include fluorescence correlation spectroscopy and dynamic light scattering to quantify aggregate size as a function of time (i.e., aggregate formation). The local bonding structure can also be probed with x-ray absorption spectroscopy (XAS), which includes both $\mathrm{x}$-ray absorption near-edge structure and extended XAFS. These techniques provide information about speciation including oxidation state and near-neighbor coordination environments out to distances of about $5 \AA$. Mass spectrometry techniques such as NanoSIMS (Novikov et al. 2006) can also identify the chemical composition of colloids with nanometer spatial resolution.

One of the key challenges, within the context of colloid characterization, is finding ways to synthesize or isolate molecular crystals suitable for structural characterization. Under favorable conditions, highenergy (>60 keV) x-ray scattering (HEXS) experiments (Soderholm et al. 2008) can be used to probe solute correlations at length scales to distances of $20 \AA$ or longer, which is important to understanding of aggregate formation.

Environmental and subsurface sampling techniques for capturing representative colloids without introducing artifacts are also difficult to implement. Current knowledge of sampling, characterization, and interaction mechanisms for colloids with metals or radionuclides was reviewed by IUPAC (Wilkinson and Lead 2007 and references therein). Sampling techniques include 1) ultrafiltration (crossflow, tangential flow, stirred cell); 2) field flow fractionation; 3) reverse osmosis; 4) electrophoresis; 5) combined electrodialysis and reverse osmosis; and 6) chromatographic (high performance liquid chromatography) and resin techniques, including size exclusion, hydrophobic resins or ion exchange. 
In situ approaches for sampling groundwater are challenging since such approaches need to have minimal disturbances due to artifactual colloids introduced during well sampling, and minimal aggregate formation or fractionation processes.

In summary, the potential importance of colloid-facilitated transport in the geologic environment has been long recognized but is difficult to predict and model owing to the complex nature of the particles and the difficulties in environmental sampling and characterization. However, strongly sorbing and/or highly insoluble radionuclides are likely to be transported in the subsurface only in association with colloids (DOE/BES 2007).

\subsection{Plutonium Colloids}

Among all of the actinide elements, plutonium is the most likely element to be transported in colloidal form in subsurface systems. This results from the fact that plutonium in the $\mathrm{Pu}(\mathrm{IV})$ oxidation state has a very low solubility over a broad range of environmental conditions (see Chapter 4). $\mathrm{Pu}$ (IV) intrinsic colloids can be easily synthesized by neutralization of acid solutions of $\mathrm{Pu}(\mathrm{IV}$ ) (Costanzo et al. 1973) or by radiolysis of $\mathrm{Pu}(\mathrm{V} / \mathrm{VI}$ ) solutions (Newton et al. 1986), can remain stable for years (Silva and Nitsche 1995) and can occur in submicron to nanometer size (Ichikawa and Sato 1984; Rundberg et al. 1987; Triay et al. 1991; Soderholm et al. 2008; Powell et al. 2011). There is also unequivocal evidence that plutonium can associate with colloidal particles containing iron, natural organic matter, carbonates, or other components to form pseudocolloids (Powell et al. 2011; Kalmykov et al. 2007; Schwantes and Santschi 2010; Novikov et al. 2009; Asbury et al. 2001). However, despite clear evidence for the formation of both intrinsic and pseudo plutonium colloids in laboratory systems, evidence for the transport of plutonium in colloidal form in field situations is much less evident. This results from a variety of factors including changes in solubility with respect to redox conditions, lack of actual field measurements, particle aggregation, and the difficulty of determining plutonium concentrations and speciation at the typically low levels in environmental systems (Buesseler et al. 2009). For example, more than two decades ago, Penrose et al. (1990) provided evidence for plutonium colloidal transport at Mortandad Canyon near the Los Alamos National Laboratory; however, subsequent detailed isotopic analysis by Marty et al. (1997) indicated that the potential for plutonium collodial transport at that site had been overstated. The two most definitive studies on the subsurface environmental transport of plutonium colloids were reported for the Nevada Test Site (Kersting et al. 1999) and at the Mayak production facility in Russia (Novikov et al. 2006) where the presence of plutonium on colloidal particles was verified by ultrafiltration and analysis by nanoSIMS and/or highly sensitive mass spectrometry methods. The total concentrations of plutonium observed in groundwater were, however, quite low $\left(<10^{-14} \mathrm{M}\right.$ at the Nevada Test Site and $0.029-4.8 \mathrm{~Bq} / \mathrm{l} \sim 5 \times 10^{-14} \mathrm{M}$ to $9 \times 10^{-12} \mathrm{M}$ plutonium-239 at Mayak).

At the Hanford Site, there has been very little study of colloidal transport of plutonium. For example, in laboratory studies, Mashal et al. (2004) identified the potential for colloid formation upon reacting Hanford Site sediments with simulated tank waste but the potential for radionuclide association with the colloids was not addressed. The only study where the potential for plutonium transport in colloidal form was directly addressed was conducted by Dai et al. (2005) who investigated plutonium colloidal transport in the 100 Area near the K Basins, where spent fuel elements were stored. Plutonium colloidal particles were identified using a combination of ultrafiltration coupled with analysis by high resolution thermal ionization mass spectrometry. However, the fraction of plutonium present as colloids ranged only from 7\%-29\% and the total plutonium concentrations were extremely low (maximum concentration 
$5 \times 10^{6}$ atoms $/ \mathrm{kg}$ ) which is $\sim 10,000$ times below EPA drinking water standards, suggesting that plutonium transport in groundwater by colloids is not a substantial process at the Hanford Site. Recent sediment leaching studies by Cantrell et al. (2008) on selected sediment samples collected from the two wells (299-W15-46 and 299-W15-48) drilled near the 216-Z-9 Trench also did not reveal the presence of colloidal particles in $0.0018 \mu \mathrm{m}$ filtrates.

The potential for colloidal transport of plutonium in the Hanford 200 Areas where the majority of the plutonium has been disposed (see Chapter 2) has never been studied in detail. For example, past and more recent studies of samples collected from the 216-Z-9 Trench indicate that plutonium may have precipitated from the original acid solutions when the solutions were at least partially neutralized upon contact with subsurface sediments. As described in previous sections, precipitated plutonium particles tend to be very small in size (i.e., nanometer) and hence, potentially more mobile than larger micron-sized plutonium particles. As partial evidence for this was the early work of Ames $(1974,1976)$ and Price and Ames (1975) which indicated the presence of plutonium in two different forms in surface sediments of the 216-Z-9 Trench. One of these types was referred to as "particulate" plutonium consisting of discrete plutonium particles (>70 wt\% plutonium), 2-25 $\mu \mathrm{m}$ in size, which were concentrated near the release points but very scarce below about $30 \mathrm{~cm}$ of sediment. X-ray diffraction and electron microprobe analysis indicated that much of this particulate plutonium was crystalline $\mathrm{PuO}_{2}$ disposed directly from Z Plant operations as suspended solids. The second type of plutonium $(<0.5 \mathrm{wt} \%$ plutonium) was apparently originally disposed as soluble $\mathrm{Pu}(\mathrm{IV})$ and precipitated upon interaction of the acidic waste with the subsurface sediments, referred to as "silicate hydrolysis." This "nonparticulate" plutonium penetrated much deeper into the subsurface than the large "particulate" plutonium. Ames $(1974,1976)$ and Price and Ames (1975) were unable to characterize the chemical form or composition of this "non-particulate" plutonium. Recent studies of these same sediments by Felmy et al. (2010) and Batuk et al. (2012) using XAS has shown the particles appear to be $\mathrm{PuO}_{2+\mathrm{x}}$ like but show a possible inclusion of phosphorus in the structure (Figure 6.1). This inclusion of phosphorus also occurs in the micron-sized particles as well. In at least partial agreement with this finding, Buck et al. (2012) identified the formation of plutonium-

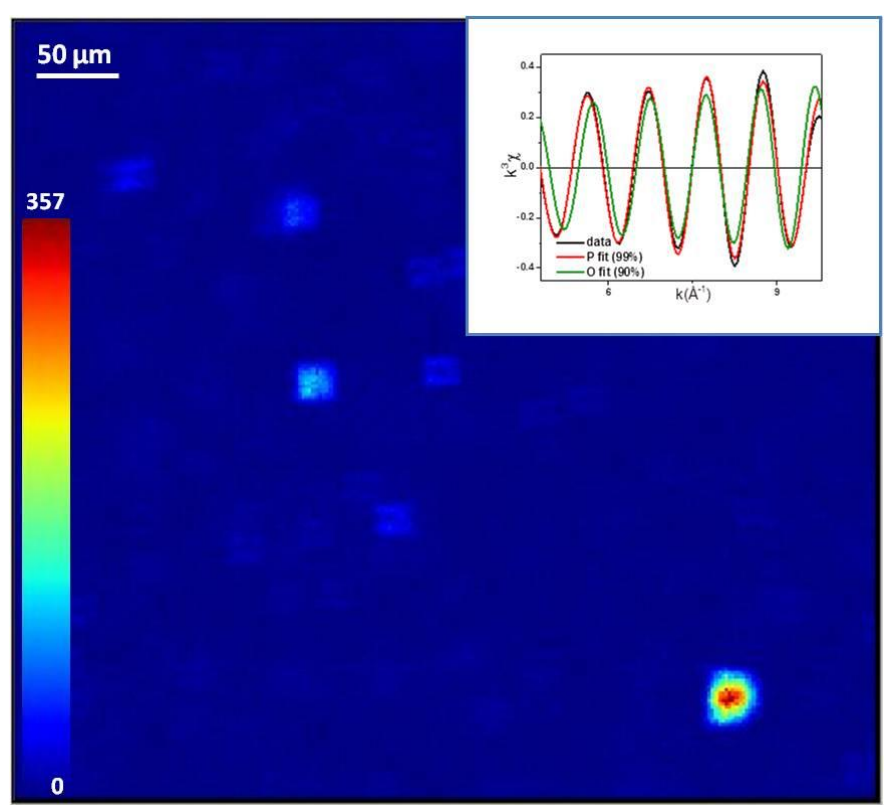

Figure 6.1. The Elemental Mapping of 216-Z-9 Crib Surface Sample and Results of a Curve Fitting for a Shell at 3.45-3.54 Å Using Both $\mathrm{Pu}-\mathrm{O}$ and $\mathrm{Pu}-\mathrm{P}$ Amplitudes and Phases Compared to the Data (Batuk et al. 2012) phosphate and plutonium silicate nanoparticles in 216-Z-9 crib sediments using high-resolution TEM, and electron energy-loss spectroscopy (Figure 6.2). High-resolution TEM, electron diffraction, and x-ray energy dispersive spectroscopy were used to examine the nature of these fine-grained plutonium phases. These unique nano-sized plutonium silico-phosphate phases in the sediments appear to have formed directly from 


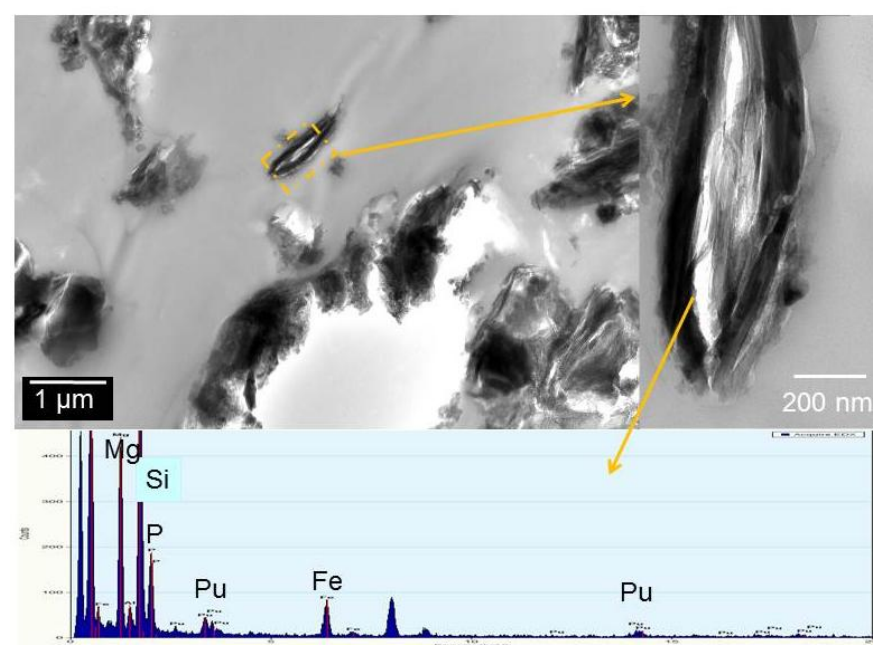

Figure 6.2. Thin-Sectioned 216-Z-9 Crib Sediment Showing the Occurrence of a PlutoniumPhosphate Region Within a Clay-Like Phase. The higher magnification image shows the strands of clay fibers. The composition is consistent with mica with $\mathrm{Mg}, \mathrm{Si}$, and $\mathrm{Fe}$ as the major components (Buck et al. 2012). solution as the acidic plutonium containing waste was neutralized by interaction with the soil. The plutonium precipitated at the mineral surface where the $\mathrm{pH}$ was higher than in the bulk solution owing to mineral dissolution. This is similar to the "silicate hydrolysis" hypothesis postulated many years ago by Price and Ames (1975). The potential for subsurface migration of such nano-sized plutonium containing particles is currently unknown.

Very recently selected samples collected from the one well (299-W15-48) drilled near the 216-Z-9 Trench described earlier, have been analyzed using scanning electron microscopy and by NanoSIMS for determination of the plutonium particle distribution (Kipps et al. 2012). The results for one of these samples (B1HY61) collected at sample depth of 65-66 ft bgs (76.5-77.5 along the slant borehole) shows the presence of plutonium both along grain boundaries and

associated with $\mathrm{CaCO}_{3}$ precipitates (Figures 6.3 and 6.4). Cantrell et al. (2008) performed $\mathrm{pH}$ measurements on water extracts of sediments located above this sample at depths of 56.8-58.5 ft and 59.4-61.1 ft bgs, (samples B1HK27 and B1HK32) that had pH values of 7.8-7.9 after 30 days of reaction. Correspondingly, the $\mathrm{pH}$ of extracts from samples located below this depth $(84.8-86.5 \mathrm{ft})$ yielded low $\mathrm{pH}$ values (i.e., 4.55) after 30 days of reaction. The occurrence of plutonium associated with carbonate containing sediments is difficult to reconcile with acidic solutions at greater depth. Several possibilities exist: 1) acidic solutions did pass through these sediments transporting plutonium but the sediments re-carbonated following the acid treatment, 2) these sediments only saw small amounts of acid solution because drilling a slant bore hole results in collection of samples that are not directly above or below each other, and 3) these sediments never saw acidic solutions, the plutonium was transported into these sediments in a non-acidic medium, most likely in a colloidal form owing to the low solubility of plutonium phases. In the latter case, lateral movement of acidic solutions below the 65-66 ft depth could result in the more acid solutions occurring at greater depth. Clearly, more extensive characterization of the plutonium containing sediment samples collected beneath the 216-Z-9 Trench will be required to distinguish among these possibilities.

The previous discussion focused on the 216-Z-9 Trench which is an example of an acidic, high-salt, organic rich waste disposal site as noted in Table 3.3. However, it is also of interest to examine the potential for colloid formation/migration at the 216-Z-12 Crib which is an example of a low-salt, alkaline waste disposal site (Table 3.3). Kasper (1982) presents a detailed description of the 216-Z-12 disposal site including the crib layout, a description of the processing solutions, and the wells drilled to assess the possible levels of contamination. The waste solutions disposed to the 216-Z-12 Crib were relatively low ionic strength $(\sim 0.15 \mathrm{M})$, slightly basic $(\mathrm{pH} \sim 8)$ and comprised principally of sodium, nitrate, and fluoride. 
The waste solutions were passed through the 216-Z-361 Settling Tank before being discharged to the 216-Z-12 Crib. As described previously, the vast majority of the plutonium and americium was retained in the top few meters of sediment at the bottom of the crib. However, the samples from the deepest well drilled (Well 299-W18-181, see Figure 6.5) also showed an increase in plutonium and americium concentration in a silt layer located approximately $40 \mathrm{~m}$ below the surface of the $216-\mathrm{Z}-12 \mathrm{Crib}$. Kasper (1982) indicated that the source of the plutonium and americium was from the 216-Z-12 Crib and not due to lateral spreading from the 216-Z-1A Tile Field or the 216-Z-18 Crib. Such observations are significant because they indicate the potential for migration of plutonium and americium deep into the subsurface even at waste sites that never received acid waste, albeit the concentration levels are apparently very low. The chemical form of this mobile plutonium/americium is currently unknown; however, transport in colloidal form is a possibility given the expected higher $\mathrm{pH}$ values and the accumulation of both plutonium and americium (from plutonium-241 decay) in the silt layer. Accumulations of plutonium and americium in underlying silt layers were also observed in sediments below the 216-Z-9 Trench. Detailed microscopic analysis of 216-Z-12 sediments may give important insight into the chemical forms of plutonium and americium in the 216-Z-12 sediments.

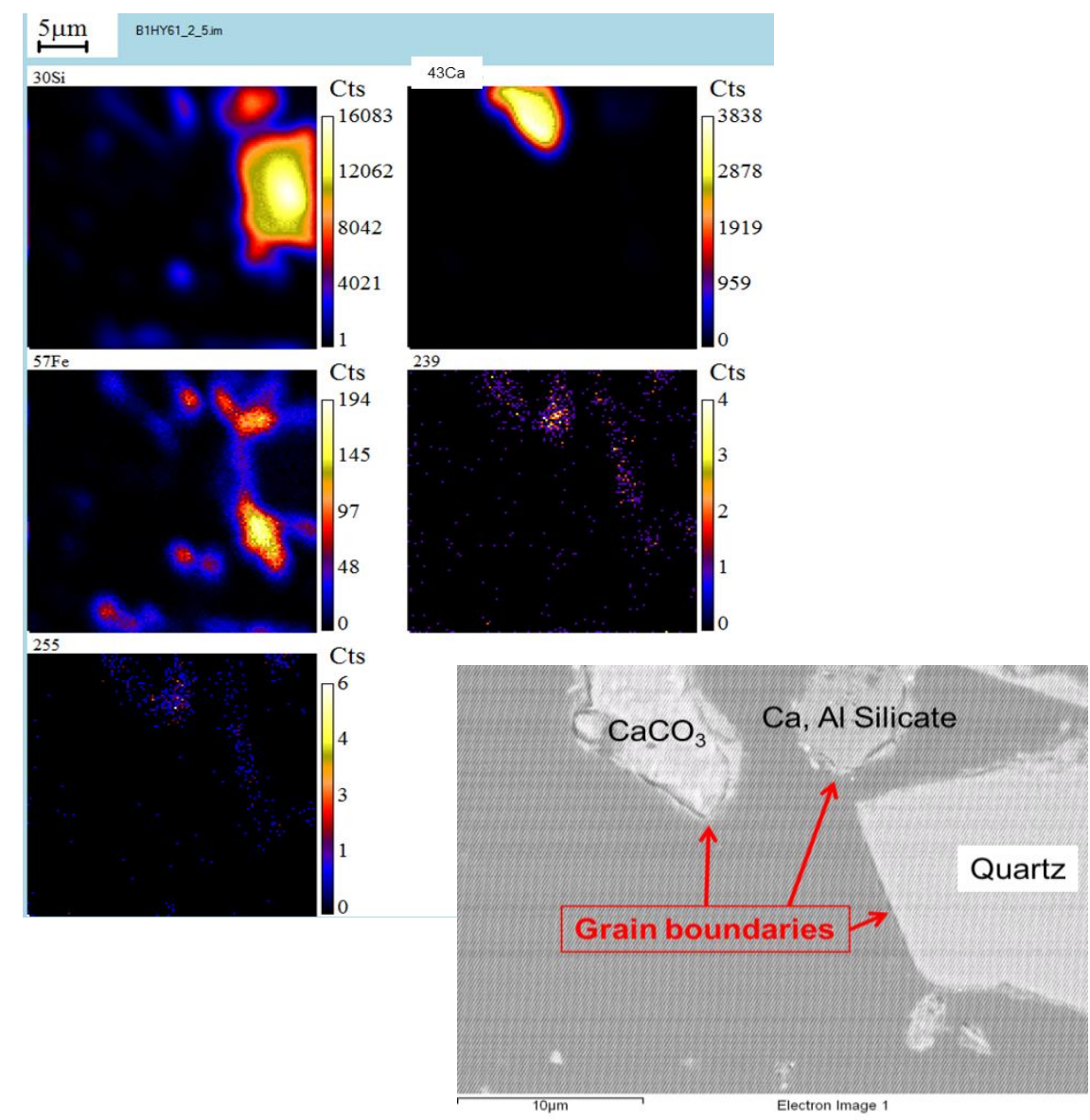

Figure 6.3. NanoSIMS and SEM Images of Individual Soil Particles Collected from Well 299-W15-48, Sample B1HY61, Collected at Sample Depths of 65-66 ft bgs. Plutonium mass spectra are shown both at molecular weight $239(\mathrm{Pu})$ and $255(\mathrm{PuO})$. Plutonium appears to be concentrated at grain boundaries on these samples. 


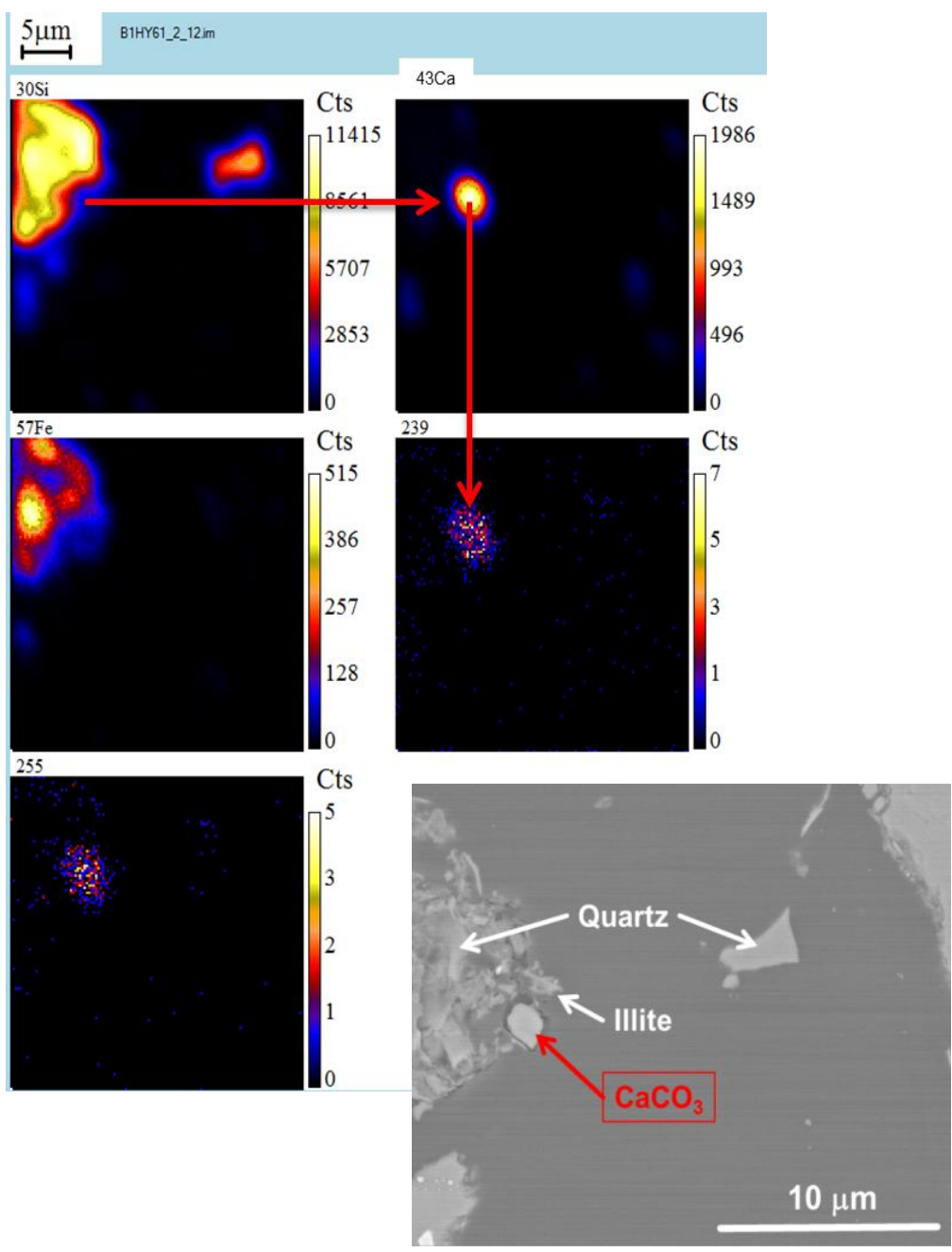

Figure 6.4. NanoSIMS and SEM Images of Individual Soil Particles Collected from Well 299-W15-48, Sample B1HY61, Collected at Sample Depths of 65-66 ft bgs. Plutonium mass spectra are shown both at molecular weight $239(\mathrm{Pu})$ and $255(\mathrm{PuO})$. Plutonium appears to be concentrated in $\mathrm{CaCO}_{3}$ precipitates.

\subsection{Americium Colloids}

In general, the formation of americium aggregates or nanoparticles through hydrolysis or other mechanisms is not expected to play a significant role in the transport of americium in subsurface environments at the Hanford Site. However, the co-disposal of TBP or other phosphate containing compounds at the Hanford Site creates the possibility for the formation of insoluble americium phosphate particles (see Section 3). In addition, significant quantities of plutonium-241 were disposed at the Hanford Site. Decay of plutonium-241 yields americium-241. Hence, if plutonium-241 is transported in colloidal form, colloidal transport can also impact the fate of americium in the subsurface. The occurrence of plutonium in phosphate compounds in the 216-Z-9 Trench sediments has implications for the possible colloidal transport of americium and needs to be considered in any future americium fate and transport analyses. 


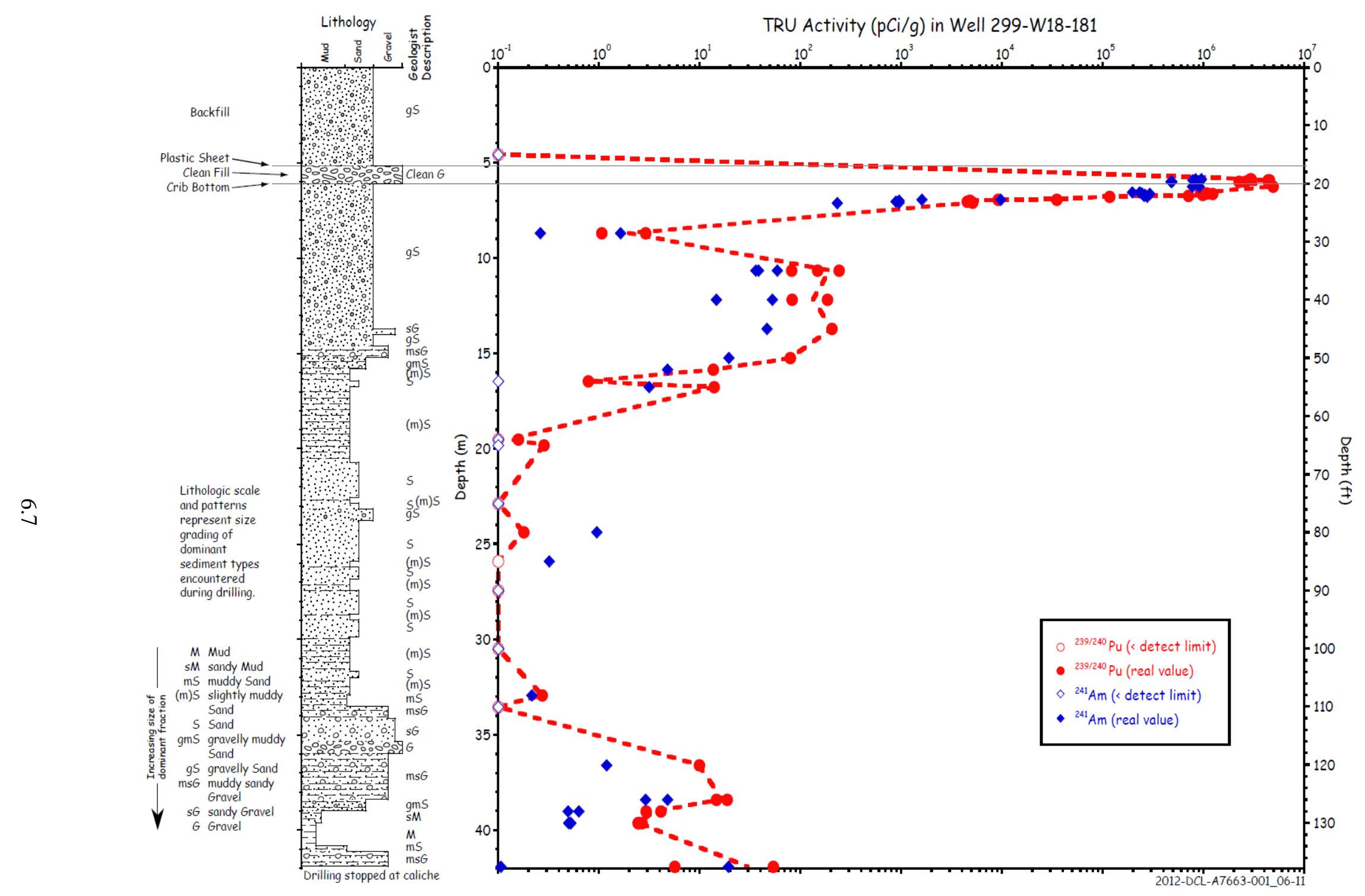

Figure 6.5. Plutonium and Americium Distributions in Well 299-W18-181 as a Function of Depth (from Kasper 1982) 


\subsection{Implications of Plutonium and Americium Colloids}

The significance of colloidal transport of plutonium and americium within the Hanford vadose zone where significant amounts of plutonium and americium wastes were disposed remains unclear. Based on data from a single study, it appears that for typical far-field conditions, colloidal transport through Hanford groundwater is not an important transport mechanism. However, the situation for waste sites significantly impacted by plutonium processing wastes is much less certain. Several lines of evidence suggest that colloidal transport may have played a role in the migration of plutonium through the vadose zone beneath waste sites during periods of active disposal. These include that fact that acidic wastes containing plutonium and americium can produce colloidal particles during acid induced weathering of sedimentary minerals in the vadose zone. Adsorption of plutonium and americium to these nascent particles and subsequent advection deeper into the vadose zone could have potentially served as a transport mechanism during active disposal. Recent studies provide evidence of the presence of nanosized particles of plutonium precipitates of variable composition in sediment samples collected below the 216-Z-9 Trench; however, it is unclear if these particles precipitated in situ or were transported as colloidal particles. The potential for remobilization of these particles during future closure scenarios is unknown. 


\subsection{Challenges and Research Needs}

The objective of this section is to identify critical unresolved questions necessary to define scientifically defensible end states and support remediation decisions for plutonium and americium at key Hanford Site disposal facilities. This information would provide the necessary understanding to provide robust conceptual models which identify the controlling processes for plutonium and americium transport and fate across the broad range of Hanford Site subsurface disposal sites.

Issue \#1: What was the mechanism responsible for the migration of plutonium and americium into the deep subsurface at disposal sites in the Hanford Site 200 West Area? The majority of the disposal sites in the 200 West Area that show plutonium and americium migration into the deep subsurface received acid wastes (i.e., 216-Z-9, 216-Z-1A, and 216-Z-18) and as a result past studies have assumed that acidic conditions were required to transport plutonium/americium. Certainly, acid facilitated transport has had some influence on the migration of plutonium/americium at these sites. However, additional factors and recent research are beginning to indicate that acid transport may not explain all of the features of the plutonium and americium distributions in the Hanford Site 200 West Area. First, at least small concentrations of plutonium and americium are found in the deep subsurface $(\sim 40 \mathrm{~m})$ at the 216-Z-12 disposal site, even though this site never received acid waste. Second, small concentrations of plutonium have also been found associated with carbonate minerals in sediments at the Z-9 disposal site indicating that such sediments never received acid waste or received only minor amounts of acid. Third, high concentrations of plutonium are found associated with TBP and non-aqueous carbon tetrachloride in silt layers below the 216-Z-9 Trench site, indicating that organic complexation and/or transport in a nonaqueous phase $\left(\mathrm{CCl}_{4}\right)$ may have had some impact on plutonium/americium distributions. Fourth, thermodynamic calculations indicate that both plutonium and americium could have precipitated as highly insoluble phosphate phases in Hanford Site sediments. In at least partial support of this, recent studies have found a plutonium phosphate phase in sediments below the 216-Z-9 Trench. The presence of this phase and its insoluble nature under acidic conditions casts doubt on acid facilitated transport as the only transport mechanism.

Issue \#2: Can plutonium and americium present at Hanford Site disposal sites be re-mobilized from the deep vadose zone and reach groundwater? As described earlier in this report, large quantities of plutonium and americium have been disposed into the Hanford Site subsurface. This large quantity of material presents a possible source term for future subsurface migration or transport. In general, the disposed plutonium and americium in Hanford Site disposal sites has been considered as immobile since plutonium tends to be highly insoluble as $\mathrm{Pu}(\mathrm{IV})$, plutonium and americium tend to adsorb strongly to many of the solid phases present in the sediments, and the vast majority of plutonium and americium in Hanford Site sediments is found in close proximity to the bottoms of the disposal facilities. Unfortunately, there have been few studies of the actual sediment materials to verify or confirm the potential for re-mobilization. Cantrell et al. (2008) did perform leaching studies of 216-Z-9 sediments taken from Wells 299-W15-46 and 299-W15-48. Only the sediments with low pH values showed measureable plutonium or americium concentrations in water extracts. However, only one composition of simulated Hanford Site groundwater was used and the water extracts with measurable plutonium/ americium were not ultrafiltered to quantify the fraction of leachable plutonium/americium that occurred as colloidal or dissolved species. 
Addressing these issues requires resolving some fundamental aspects of the chemistry of plutonium and americium in the subsurface. Specifically, these research challenges address the chemical behavior of the Hanford Site sediments in response to different waste compositions, and the re-mobilization of plutonium/americium in either aqueous vadose zone pore water or in non-aqueous solvents, and ultimately groundwater. Studies to address these challenges are embodied in the following research statements with specific research needs highlighted within each challenge.

Research Challenge \#1: Determine the transformations of Hanford Site sediments in response to changes in waste/vadose zone porewater composition. This effort would be similar to previous studies done on Hanford Site sediments using tank waste simulants. These studies, using simulants of the Z Plant waste streams (details in Appendix D of Corbin et al. 2005) will yield information on acid neutralizing capacity, the mineral transformations that take place and the possible generation of pseudo colloids that could facilitate plutonium/americium migration. The reacted sediments will need to be analyzed with high resolution microscopy methods to precisely determine the reaction products formed and their spatial distribution.

Research Challenge \#2: Assess the potential for plutonium/americium solubilization or colloid formation. A range of $\mathrm{pH}$ and redox conditions will need to be studied in well controlled laboratory experiments of Hanford sediments to determine under what specific environmental conditions each remobilization mechanism (e.g. solubility, adsorption, colloid formation) is active. A critical part of this task will be the characterization of the chemical form of the plutonium and americium in the contaminated Hanford Site sediments proximal and beneath the inactive trenches, cribs and tile files that received Z Plant wastes. Knowledge of the chemical form will be crucial in terms of evaluating the potential for solublization, colloid formation or the remobilization of adsorbed complexes. Identification of the chemical form will also allow the preparation and testing of the reactivity of model materials (based upon the determination of the chemical form such as in the case of the plutonium phosphates/silicates), as well as use of actual Hanford Site sediments.

Research Challenge \#3: Establish the role of organic complexants and/or non-aqueous solvents in the transport of plutonium/americium in the deep subsurface. Although it is extremely unlikely that nonaqueous solvents will ever be introduced into the Hanford Site subsurface in the future, past releases of significant quantities (e.g., TBP, carbon tetrachloride, lard oil) have occurred. Hence it is important to establish the role of non-aqueous solvent in past movement of plutonium and its potential role in future mobility. Also, it appears that plutonium is currently associated with TBP and the presence of nonaqueous solvents, at least in certain Z-9 sediments. If confirmed, such a co-association could impact the formulation of future remediation strategies

In addition to the research needs described in this section, the proposed work will provide valuable and technically defensible information to address issues and concerns raised by regulatory agencies, stakeholders and review panels; for example, Alvarez (2011) and International Panel on Fissile Materials (2010). 


\subsection{References}

Allard B, U Olofsson, and B Torstenfelt. 1984. "Environmental Actinide Chemistry." Inorganica Chimica Acta 94:205-221.

Allard B and J Rydberg. 1983. "Behavior of Plutonium in Natural Waters." In Plutonium Chemistry, ACS Symposium Series 216, WT Carnall and GR Choppin (eds), pp. 275-295, American Chemical Society, Washington, D.C.

Alonso U and C Degueldre. 2003. "Modelling americium sorption onto colloids: Effect of redox potential." Colloids and Surfaces A: Physiochemical and Engineering Aspects 217:55-62.

Alvarez RA. 2011. "Plutonium Wastes from the U.S. Nuclear Weapons Complex." Science \& Global Security: The Technical Basis for Arms Control, Disarmament, and Nonproliferation Initiatives 19(1):15-27.

Ames LL. 1974. Characterization of Actinide Bearing Soils: Top Sixty Centimeters of 216-Z-9 Enclosed Trench. BNWL-1812, Pacific Northwest Laboratories, Richland, Washington.

Ames LL. 1976. Proceedings of an Actinide-Sediment Reactions Working Meeting at Seattle, Washington on February 10-11, 1976. BNWL-2117, Pacific Northwest National Laboratories, Richland, Washington.

ARH - Atlantic Richfield Hanford Company. 1977. Evaluation of Scintillation Probe Profiles from 200 Area Crib Monitoring Wells. ARH-ST-156, Richland, Washington.

Asbury SML, SP Lamont, and SB Clark. 2001. "Plutonium partitioning to colloidal and particulate matter in an acidic, sandy sediment: Implications for remediation alternatives and plutonium migration." Environmental Science \& Technology 35:2295-2300.

Batuk ON, SD Conradson, H Boukhalfa, BE Burakov, DL Clark, KR Czerwinski, AR Felmy, JS LezamaPacheco, SN Kalmykov, DA Moore, BF Myasoedov, DD Reilly, RC Roback, IE Vlasova, SM Webb, and MP Wilkerson. 2012. "Environmental and forensic chemistry of U and Pu at Chernobyl, McGuire AFB, Mayak, Rocky Flats, Hanford, and Los Alamos." Nature (submitted).

Belaid S and C Chachaty. 1982. "NMR and electron-spin-resonance evidence of molecular aggregates in sodium dibutyl phosphate aqueous-solutions." Journal of Colloid and Interface Science 86:277-281.

BHI - Bechtel Hanford, Inc. 1995. DNAPL Investigation Report. BHI-00431, Rev. 0, Richland, Washington.

Bogdanov FA, TB Belyaeva, LP Sokhina, and AS Solovkin. 1979. "Di-normal-butyl phosphates of trivalent plutonium and americium." Soviet Radiochemistry 21:786-788.

Bowles NA and VJ Rohay. 2007. Borehole Summary Report for Slant Well 299-W15-48

(Borehole C3427) Drilled at the 216-Z-9 Trench. WMP-30566, Fluor Hanford, Inc., Richland, Washington. 
Boyanov MI, EJ O'Loughlin, EE Roden, JB Fein, and KM Kemner. 2007. “Adsorption of Fe(II) and U(VI) to carboxyl-functionalized microspheres: The influence of speciation on uranyl reduction studied by titration and XAFS." Geochimica et Cosmochimica Acta 71:1898-1912.

Brown RE and HG Ruppert. 1950. The Underground Disposal of Liquid Wastes at the Hanford Works, Washington. HW-17088, General Electric Company, Hanford Atomic Products Operation, Richland, Washington.

Buck EC, AR Felmy, DA Moore, and KR Czerwinski. 2012. "Nature of Nanosized Plutonium Particles in the Hanford 216-Z9 Crib Sediments." In American Chemical Society Spring Meeting 2012, San Diego, California.

Buesseler KO, DI Kaplan, M Dai, and S Pike. 2009. "Source-dependent and source-independent controls on plutonium oxidation state and colloid associations in groundwater." Environmental Science \& Technology 43:1322-1328.

Buffle $\mathrm{J}$ and $\mathrm{H}$ van Leeuwen (eds.). 1992. Environmental Particles. International Union of Pure and Applied Chemistry (IUPAC) Series on Analytical and Physical Chemistry of Environmental Systems, Lewis Publishers, Boca Raton, Florida.

Cantrell KJ. 2009. Transuranic Contamination in Sediment and Groundwater at the U.S. DOE Hanford Site. PNNL-18640, Pacific Northwest National Laboratory, Richland, Washington.

Cantrell KJ and RG Riley. 2008. A Review of Subsurface Behavior of Plutonium and Americium at the 200-PW-1/3/6 Operable Units. PNNL-SA-58953, Pacific Northwest National Laboratory, Richland, Washington.

Cantrell KJ, KN Geiszler, and BW Arey. 2008. Plutonium Mobility Studies: 216-Z-9 Trench Sample Analysis Results. PNNL-17839, Pacific Northwest National Laboratory, Richland, Washington.

Cantrell KJ, RJ Serne, and GV Last. 2003. Hanford Contaminant Distribution Coefficient Database and Users Guide. PNNL-13895, Rev. 1, Pacific Northwest National Laboratory, Richland, Washington.

Choppin GR. 2007. “Actinide Speciation in the Environment." Journal of Radioanalytical and Nuclear Chemistry 273:695-703.

Choppin GR. 1983. "Solution Chemistry of the Actinides.” Radiochimica Acta 32:43-53.

Choppin GR and A Morgenstern. 2001. "Distribution and movement of environmental plutonium." In Plutonium in the environment, ed. A. Kudo, pp. 91-105.

Cleveland JM. 1979. The Chemistry of Plutonium. American Nuclear Society, La grange Park, Illinois.

Connick RE. 1949. "Mechanism of Disproportionation of Plutonium(V)." Journal of the American Chemical Society 71:1528-1533. 
Connick RE and WH McVey. 1953. "Disproportionation Equilibria and Rates in Perchloric and Hydrochloric Acid Solutions of Plutonium: Influence of a-Particles." Journal of the American Chemical Society 75:474-479.

Corbin RA, BC Simpson, MJ Anderson, WF Danielson III, JG Field, TE Jones, and CT Kincaid. 2005. Hanford Soil Inventory Model, Rev. 1. RPP-26744, CH2M HILL Hanford Group, Richland, Washington.

Costanzo DA, RE Biggers, and JT Bell. 1973. "Plutonium Polymerization - I. A Spectrophotometric Study of the Polymerization of Plutonium(IV)." Journal of Inorganic Nuclear Chemistry 35:609-622.

Curtis GP, JA Davis, and DL Naftz. 2006. "Simulation of reactive transport of uranium(VI) in groundwater with variable chemical conditions." Water Resources Research 42:W04404, doi:10.1029/2005WR003979.

Dai MH, K Buesseler, and SM Pike. 2005. "Plutonium in groundwater at the 100K-Area of the US DOE Hanford Site. Journal of Contaminant Hydrology 76:167-189.

Davis JA, JA Coston, DB Kent, and CC Fuller. 1998. "Application of the surface complexation concept to complex mineral assemblages.” Environmental Science \& Technology 32:2820-2828.

Davis JA, M Ochs, M Olin, TE Payne, and CJ Tweed. 2005. Interpretation and Prediction of Radionuclide Sorption onto Substrates Relevant for Radioactive Waste Disposal Using Thermodynamic Sorption Models. NEA Sorption Project, Phase II, NEA Report 5992, OECD, Paris, France.

Davis JA, TE Payne, and TD Waite. 2002. "Simulating the $\mathrm{pH}$ and $\mathrm{pCO}_{2}$ dependence of uranium(VI) adsorption by a weathered schist with surface complexation models." In PC Zhang and PV Brady (ed.) Geochemistry of Soil Radionuclides. SSSA Special Pub. 59, p. 61-86, SSSA, Madison, Wisconsin.

Deditius AP, S Utsunomiya, and RC Ewing. 2008. "The chemical stability of coffinite, $\mathrm{USiO}_{4} \cdot \mathrm{nH}_{2} \mathrm{O}$; $0<\mathrm{n}<2$, associated with organic matter: A case study from Grants uranium region, New Mexico, USA. Chemical Geology 251:33-49.

Degueldre C, HJ Ulrich, and H Silby. 1994. "Sorption of ${ }^{241}$ Am onto Montmorillonite, Illite and Hematite Colloids." Radiochimica Acta 65:173-179.

Delegard CH and GS Barney. 1983. Effects of Hanford High-Level Waste Components on Sorption of Cobalt, Strontium, Neptunium, Plutonium, and Americium of Hanford Sediments. RHO-RE-ST-1 P, Rockwell Hanford Operations, Richland, Washington.

DOE/BES. 2007. Basic Research Needs for Geosciences: Facilitating $21^{\text {st }}$ Century Energy Systems. Bethesda, Maryland.

DOE/DP. 1996. Plutonium: The First 50 Years. DOE/DP-0137, U.S. Department of Energy, Washington D.C.

DOE/EM. 1997. Linking Legacies - Connecting the Cold War Nuclear Weapons Production Processes to Their Environmental Consequences. DOE/EM-0319, U.S. Department of Energy, Washington, D.C. 
DOE/RL. 1992. Z Plant Source Aggregate Area Management Study Report. DOE/RL-91-58, Rev. 0, U.S. Department of Energy, Richland Operations Office, Richland, Washington.

DOE/RL. 1996. 200-BP-5 Operable Unit Treatability Test Report. DOE/RL-95-59 Rev. 0, U.S. Department of Energy, Richland Operations Office, Richland, Washington.

DOE/RL. 2002. History of the Plutonium Production Facilities at the Hanford Site Historical District, 1943-1990. DOE/RL-97-1047 Rev. 0, U.S. Department of Energy, Richland Operations Office, Richland, Washington.

DOE/RL. 2007. Remedial Investigation Report for the Plutonium/Organic-Rich Process Condensate/ Process Waste Group Operable Unit: Includes the 200-PW-1, 200-PW-3, and 200-PW-6 Operable Units. DOE/RL-2006-51, Rev. 0, U.S. Department of Energy, Richland Operations Office, Richland, Washington.

DOE/RL. 2008. Hanford Site Groundwater Monitoring for Fiscal Year 2007. DOE/RL-2008-01, U.S. Department of Energy, Richland Operations Office, Richland, Washington.

DOE/RL. 2010. Hanford Site Groundwater Monitoring Report for 2009. DOE/RL-2010-11, Rev. 1, U.S. Department of Energy, Richland, Washington.

Dreissig I, S Weiss, C Hennig, G Bernhard, and H Zaenker. 2011. "Formation of uranium(IV)-silica colloids at near-neutral pH." Geochimica et Cosmochimica Acta 75:352-367.

EPA - U.S. Environmental Protection Agency. 1999. Understanding Variation in Partition Coefficient, $K_{d}$, Values: Volume II: Review of Geochemistry and Available $K_{d}$ Values for Cadmium, Cesium, Chromium, Lead, Plutonium, Radon, Strontium, Thorium, Tritium $\left({ }^{3} \mathrm{H}\right)$ and Uranium.

EPA 402-R-99-004B, prepared for U.S. Environmental Protection Agency, Washington, D.C., by Pacific Northwest National Laboratory, Richland, Washington.

EPA - U.S. Environmental Protection Agency. 2004. Understanding Variation in Partition Coefficient, $K_{d}$, Values: Volume III: Review of Geochemistry and Available $K_{d}$ Values for Americium, Arsenic, Curium, Iodine, Neptunium, Radium, and Technetium. EPA 402-R-04-002C, prepared for U.S. Environmental Protection Agency, Washington, D.C., by Pacific Northwest National Laboratory, Richland, Washington.

EPA - U.S. Environmental Protection Agency. 2011. Record of Decision, Hanford 200 Area Superfund Site, 200-CW-5 and 200-PW-1, 200-PW-3, AND 200-PW-6 Operable Units, U.S. Environmental Protection Agency, Richland, Washington.

Felmy AR, KJ Cantrell, and SD Conradson. 2010. "Plutonium contamination issues in Hanford soils and sediments: Discharges from the Z-Plant (PFP) complex." Physics and Chemistry of the Earth 35:292-297.

Fjeld RA, SM Serkiz, PL McGinnis, AI Elci, and DI Kaplan. 2003. "Evaluation of a conceptual model for the subsurface transport of plutonium involving surface mediated reduction of $\mathrm{Pu}(\mathrm{V})$ to $\mathrm{Pu}(\mathrm{IV})$." Journal of Contaminant Hydrology 67:79-94. 
Gephart RE. 2010. "A Short History of Waste Management at the Hanford Site.” Physics and Chemistry of the Earth 35:298-306.

Goldberg S, LJ Criscenti, DR Turner, JA Davis and Kirk J. Cantrell. 2007. “Adsorption-Desorption Processes in Subsurface Reactive Transport Modeling." Vadose Zone Journal 6:407-435.

Grant KE, GM Mong, SA Clauss, KL Wahl, and JA Campbell. 1997. "Determination of monobutyl phosphate and dibutyl phosphate in mixed hazardous wastes by ion-pair chromatography." Journal of Radioanalytical and Nuclear Chemistry 220(1):31-35.

Guillaumont R, FJ Mompean, T Fanghänel, J Fuger, I Grenthe, V Neck, DA Palmer, and ML Rand. 2003. Chemical Thermodynamics, Volume 5: Chemical Thermodynamics of Uranium, Neptunium, Plutonium, Americium, and Technetium. Elsevier Science Publishing Company, New York.

Hajek BF and KC Knoll. 1966. Disposal Characteristics of Plutonium and Americium in a High Salt Acid Waste. BNWL-CC-649, Battelle Pacific Northwest Laboratories, Richland, Washington.

Haschke JM, TH Allen and LA Morales. 2000. "Reaction of Plutonium Dioxide with Water: Formation and Properties of $\mathrm{PuO}_{2+\mathrm{x}}$." Science 287:285-287.

Haschke JM. 2007. "Disproportionation of $\mathrm{Pu}(\mathrm{IV})$ : A reassessment of kinetic and equilibrium properties." Journal of Nuclear Materials 362:60-74.

Hixon AE, YJ Hu, DI Kaplan, RK Kukkadapu, H Nitsche, O Qafoku and BA Powell. 2010. "Influence of iron redox transformations on plutonium sorption to sediments.” Radiochim. Acta 98, 685-692.

HNF - Fluor Daniel Hanford, Inc. 1997. History and Stabilization of the Plutonium Finishing Plant (PFP) Complex, Hanford Site. HNF-EP-0924, Richland, Washington.

Honeyman BD. 1984. Cation and Anion Adsorption at the Oxide/Solution Interface in Systems Containing Binary Mixtures of Adsorbents: An Investigation of the Concept. Ph.D. Dissertation, Stanford University, Stanford, California.

Ichikawa F and T Sato. 1984. "On the Particle Size Distribution of Hydrolyzed Plutonium(IV) Polymer." Journal of Radioanalytical and Nuclear Chemistry 84:269-275.

Iida M and Y Hata. 1992. "NMR relaxation studies for sodium and potassium-ions and water-molecules in concentrated aqueous-solutions of dibutyl phosphate." Bulletin of the Chemical Society of Japan 65:707-714.

International Panel on Fissile Materials. 2010. Global Fissile Material Report 2010 Balancing the Books: Production and Stocks. Fifth annual report. Available at http://fissilematerials.org/library/2010/12/global_fissile_material_report_4.html.

Kalmykov SN, VV Kriventsov, YA Teterin, and AP Novikov. 2007. "Plutonium and neptunium speciation bound to hydrous ferric oxide colloids." Comptes Rendus Chimie 10:1060-1066. 
Kaplan DI, BA Powell, DI Demirkanli, RA Fjeld, FJ Molz, SM Serkiz, SM, and JT Coates. 2004. "Influence of oxidation states on plutonium mobility during long-term transport through an unsaturated subsurface environment." Environmental Science \& Technology 38:5053-5058.

Kasper RB. 1982. 216-Z-12 Transuranic Crib Characterization: Operational History and Distribution of Plutonium and Americium. RHO-ST-44, Rockwell Hanford Operations, Richland, Washington.

Keeney-Kennicutt WL and JW Morse. 1985. "The redox chemistry of $\mathrm{Pu}(\mathrm{V}) \mathrm{O}_{2}{ }^{+}$interaction with common mineral surfaces in dilute solutions and seawater. Geochimica et Cosmochimica Acta 49:2577-2588.

Keller C. 1973. "Binary and Ternary Oxides, Hydroxides and Hydrous Oxides, Peroxides, Phosphates and Arsenates." In Comprehensive Inorganic Chemistry Vol. 5 Actinides, eds JC Bailar, HJ Emeleus, R Nyhom, and AF Trotman-Dickenson, pp. 219-276, Pergamon, Oxford, London.

Kent DB, RH Abrams, JA Davis, JA Coston, and DR LeBlanc. 2000. "Modeling the influence of variable $\mathrm{pH}$ on the transport of zinc in a contaminated aquifer using semiempirical surface complexation models." Water Resources Research 36:3411-3425.

Kersting AB, DW Efurd, DL Finnegan, DJ Rokop, DK Smith, and JL Thompson. 1999. "Migration of plutonium in ground water at the Nevada Test Site." Nature 397:56-59.

Kips R, PK Weber, M Zavarin, AR Felmy, and AB Kersting. 2012. "Investigating the Transport of Plutonium in Vadose Zone Sediments at the Hanford Site using NANOSIMS." In American Chemical Society Spring Meeting 2012, San Diego, California.

Korzhavyi PA, L Vitos, DA Andersson, , and B Johansson. 2004. "Oxidation of plutonium dioxide." Nature Materials 3:225-228.

Last GV, EJ Freeman, KJ Cantrell, MJ Fayer, GW Gee, WE Nichols, BN Bjornstad, and DG Horton. 2006. Vadose Zone Hydrogeology Data Package for Hanford Assessments. PNNL-14702, Rev. 1, Pacific Northwest National Laboratory, Richland, Washington.

Lavallee C and TW Newton. 1972. "Kinetics of the reaction between the chromium(III)-plutonium(V) complex and plutonium(III) in aqueous perchlorate solutions." Inorganic Chemistry 11:2616-2621.

Lemire RJ, J Fuger, H Nitsche, P Potter, MH Rand, J Rydbrg, K Spahiu, JC Sullivan, WJ Ullman, P Vitorge, and H Wanner. 2001. Chemical Thermodynamics, Volume 4: Chemical Thermodynamics of Neptunium and Plutonium. Elsevier Science Publishing Company, Inc., New York.

Lu N, PW Reimus, GR Parker, JL Conca, and IR Triay. 2003. "Sorption kinetics and impact of temperature, ionic strength and colloid concentration on the adsorption of plutonium-239 by inorganic colloids." Radiochimica Acta 91:713-720.

Lujaniene G, P Benes, K Stamberg, J Sapolaite, D Vopalka, E Radzuute, and T Sciglo. 2010. "Effect of natural clay components on sorption of $\mathrm{Cs}, \mathrm{Pu}$ and Am by the clay." Journal of Radioanalytical and Nuclear Chemistry 286:353-359. 
Marty RC, D Bennett, and P Thullen. 1997. "Mechanism of plutonium transport in a shallow aquifer in Mortandad Canyon, Los Alamos National Laboratory, New Mexico.” Environmental Science \& Technology 31:2020-2027.

Mashal K, JB Harsh, M Flury, AR Felmy, and HT Zhao. 2004. "Colloid formation in Hanford sediments reacted with simulated tank waste.” Environmental Science \& Technology 38:5750-5756.

Morss LR. 1986. "Chapter 17. Thermodynamic Properties." In The Chemistry of the Actinide Elements $2^{\text {nd }}$ Ed. Vol. 2, eds JJ Katz, GT Seaborg, and LR Morss, pp. 1278-1360, Chapman and Hall, London.

Moulin V, P Robouch, P Vitorge, and B Allard. 1988. "Environmental Behavior of Americium(III) in Natural Waters." Radiochimica Acta 44/45:33-37.

Moulin V, J Tits, and G Ouzounian. 1992. "Actinide Speciation in the Presence of Humic Substances in Natural Water Conditions.” Radiochimica Acta 58/59:179-190.

Murphy R J, JJ Lenhart, and BD Honeyman. 1999. "The sorption of thorium(IV) and uranium(VI) to hematite in the presence of natural organic matter." Colloids and Surfaces A: Physicochemical and Engineering Aspect 157:47-62.

Newton TW, DE Hobart, and PD Palmer. 1986. "The Formation of Pu(IV)-Colloid by the AlphaReduction of $\mathrm{Pu}(\mathrm{V})$ or $\mathrm{Pu}(\mathrm{VI})$ in Aqueous Solutions." Radiochimica Acta 39:139-147.

Novikov AP, SN Kalmykov, S Utsunomiya, RC Ewing, F Horreard, A Merkulov, SB Clark, VV Tkachev, and BF Myasoedov. 2006. "Colloid transport of plutonium in the far-field of the Mayak Production Association, Russia.” Science 314:638-641.

Novikov AP, SN Kalmykov, EV Kuzovkina, BF Myasoedov, K Fujiwara, and A Fujiwara. 2009. "Evolution of actinide partitioning with colloidal matter collected at PA "Mayak" site as studied by sequential extraction.” Journal of Radioanalytical and Nuclear Chemistry 280:629-634.

Oostrom M, ML Rockhold, PD Thorne, MJ Truex, GV Last, and VJ Rohay. 2007. "Carbon tetrachloride flow and transport in the subsurface of the 216-Z-9 trench at the Hanford Site." Vadose Zone Journal 6:971-984.

Painter S, V Cvetkovic, D Pickett, DR Turner. 2002. "Significance of kinetics for sorption on inorganic colloids: modeling and experiment interpretation issues." Environmental Science \& Technology 36:5369-5375.

Pasquiou JY, J Livet, M Germain, and C Musikas. 1987. "Pu(IV)-dibutylphosphate Complexes in the PUREX Process.” In The Institution of Chemical Engineers Symposium Series, No. 103:207-216. Institution of Chemical Engineers, Rugby, Warwickshire.

Payne TE, JA Davis, M Ochs, M Olin, and CJ Tweed. 2004. "Uranium adsorption on weathered schist: Intercomparison of modelling approaches." Radiochimica Acta 92:651-661. 
Penrose WR, WL Polzer, EH Essington, DM Nelson, and KA Orlandini. 1990. "Mobility of plutonium and americium through a shallow aquifer in a semiarid region." Environmental Science \& Technology 24:228-234.

Pointeau V, AP Deditius, F Miserque, D Renock, U Becker, J Zhang, N Clavier, N Dacheux, C Poinssot, and RC Ewing. 2009. "Synthesis and characterization of coffinite." Journal of Nuclear Materials 393:449-458.

Price SM and LL Ames. 1975. Characterization of Actinide-Bearing Sediments Underlying Liquid Waste Disposal Facilities at Hanford. ARH-SA-232, Atlantic Richfield Hanford Company, Richland, Washington.

Price SM, RB Kasper, MK Additon, RM Smith, and GV Last. 1979. Distribution of Plutonium and Americium beneath the 216-Z-1A Crib: A Status Report. RHO-ST-17, Rockwell Hanford Operations, Richland, Washington.

Powell B, R Fjeld, D Kaplan, J Coates, and S Serkiz. 2005. " $\mathrm{Pu}(\mathrm{V}) \mathrm{O}_{2}{ }^{+}$adsorption and reduction by synthetic hematite and goethite." Environmental Science \& Technology 39:2107-2114.

Powell BA, ZR Dai, M Zavarin, PH Zhao, and AB Kersting. 2011. "Stabilization of plutonium nanocolloids by epitaxial distortion on mineral surfaces." Environmental Science \& Technology 45:2698-2703.

Rabideau SW. 1953. "Equilibria and Reaction Rates in the Disproportionation of Pu(1V)." Journal of the American Chemical Society 75:798-801.

Rabideau SW and HD Cowan. 1955. "Chloride Complexing and Disproportionation of $\mathrm{Pu}(1 \mathrm{~V})$ in Hydrochloric Acid." Journal of the American Chemical Society 77:6145-6148.

Rai D and JL Ryan. 1982. "Crystallinity and Solubility of Pu(IV) Oxide and Hydrous Oxide in Aged Aqueous Suspensions.” Radiochimica Acta 30:213-216.

Rhodes DW. 1952. Preliminary Studies of Plutonium Adsorption in Hanford Soil. HW-24548, Hanford Works, Richland, Washington.

Rhodes DW. 1957. "The Adsorption of Pu by Soil.” Soil Science 84:465-471.

Ridgway KR, MD Veatch and DT Crawley. 1971. 216-Z-9 Crib History and Safety Analysis. ARH-2207, Atlantic Richfield Hanford Company, Richland, Washington.

RHO - Rockwell Hanford Operations. 1978. Report on Plutonium Mining Activities at 216 Z 9 Enclosed Trench. RHO-ST-21, Richland, Washington.

Romanchuk AY, SN Kamykov, and RA Aliev. 2011. "Plutonium sorption onto hematite colloids at femto- and nanomlar concentrations." Radiochimica Acta 99:137-144. 
Routson RC, G Jansen, and AV Robinson. 1975. Sorption of 99Tc, 237Np and 241Am on Two Subsoils from Differing Weathering Intensity Areas. BNWL-1889, Battelle Pacific Northwest Laboratories, Richland, Washington.

Routson RC, G Jansen, and AV Robinson. 1976. "241-Am, 237-Np, and 99-Tc Sorption on Two United States Subsoils from Differing Weathering Intensity Areas.” Health Physics 33:311-317.

Rundberg RS, AJ Mitchell, IR Triay, and NB Torstenfelt. 1987. "Size and Density of A ${ }^{242} \mathrm{Pu}$ Colloid." Material Research Society Proceedings 112:243.

Runde W. 2000. "The Chemical Interactions of Actinides in the Environment." Los Alamos Science 26:392-411.

Sanchez AL, JW Murray, and TH Sibley. 1985. "The adsorption of plutonium IV and plutonium V on goethite." Geochimica et Cosmochimica Acta 49:2297-2307.

Schwantes JM. 2004. Re-evaluating Effects of Sorption Kinetics on Colloid-Enhanced Migration of Plutonium. Waste Management '04, (February 29-March 4, 2004), Tucson, Arizona. (February 29March 4, 2004)

Schwantes JM and PH Santschi. 2010. "Mechanisms of plutonium sorption to mineral oxide surfaces: New insights with implications for colloid-enhanced migration." Radiochimica Acta 98:737-742.

Scoazec H, JY Pasquiou, and M Germain. 1990. "Some Plutonium IV Polymers Properties in PUREX Process." In The Institution of Chemical Engineers Symposium Series No. 119, Institution of Chemical Engineers, Rugby, Warwickshire.

SGW. 2009. Z Plant Complex Waste Streams Discharged to the Soil Column (1949 to 1973).

SGW-39385, Rev. 0, CH2M HILL, Richland, Washington.

Shaughnessy DA, H Nitsche, CH Booth, DK Shuh, GA Waychunas, RE Wilson, H Gill, KJ Cantrell, and RJ Serne. 2003. "Molecular Interfacial Reactions between $\mathrm{Pu}(\mathrm{VI})$ and Manganese Oxide Minerals Manganite and Hausmannite.” Environmental Science \& Technology 37(15):3367-3374.

Sheka ZA and EI Sinyavskaya. 1964a. "The solubility of lanthanum dibutyl phosphate in sulphuric and nitric acids." Russian Journal of Inorganic Chemistry 9:1212-1215.

Sheka ZA and EI Sinyavskaya. 1964b. "Solubility of rare-earth dialkyl phosphates in water." Russian Journal of Inorganic Chemistry 9:1065-1068.

Shilov VP, AV Gogolev, and AM Fedoseev. 2011. "Mechanism of Pu(VI) and Pu(V) Autoreduction in Aqueous Solutions.” Radiochemistry 53:466-473.

Silva RJ and H Nische. 1995. “Actinide Environmental Chemistry.” Radiochimica Acta 70/71:377-396.

Silva RJ, G Bidoglio, MH Rand, PB Robouch, H Wanner and I Puigdomenech. 1995. Chemical Thermodynamics, Volume 2: Chemical Thermodynamics of Americium. Elsevier Science Publishing Company, Inc., New York. 
Silver GL. 2011. "Plutonium hydrolysis and disproportionation reactions." Journal of Radioanalytical and Nuclear Chemistry 288:257-260.

Smith AE. 1973. Nuclear Reactivity Evaluations of 216-Z-9 Enclosed Trench. ARH-2915, Atlantic Richfield Hanford Company, Richland, Washington.

Smith RM. 1980. 216-B-5 Reverse Well Characterization Study. RHO-ST-37, Rockwell Hanford Operations, Richland, Washington.

Soderholm L, PM Almond, S Skanthakumar, RE Wilson, and PC Burns. 2008. "The structure of the plutonium oxide nanocluster $\left[\mathrm{Pu}_{38} \mathrm{O}_{56} \mathrm{Cl}_{54}\left(\mathrm{H}_{2} \mathrm{O}\right)_{8}\right]^{14-}$." Angewandte Chemie-International Edition 47:298-302.

Solovkin AS and AV Lobanov. 1990. "Determination of the composition of compounds formed in the extraction systems H2O-HNO3-diluent-TBP(TIAP)-DBP (DIAP)-Pu(IV).” Soviet Radiochemistry $32: 218-220$.

Stollenwerk KG. 1998. "Molybdate transport in a chemically complex aquifer: Field measurements compared with solute-transport model predictions." Water Resources Research 34:2727-2740.

Thomas RAP and LE Macaskie. 1998. "The effect of growth conditions on the biodegradation of tributyl phosphate and potential for the remediation of acid mine drainage waters by a naturally-occurring mixed microbial culture." Applied Microbiology and Biotechnology 49:202-209.

Tkac P and A Paulenovea. 2010. "Spectroscopic identification of tri-n-butyl phosphate adducts with $\mathrm{Pu}(\mathrm{IV})$ hydrolyzed species.” IOP Conf. Series: Materials Science and Engineering 9:1-7.

Toth LM, JT Bell and HA Fiedman. 1990. "The Disproportionation of Pu-4+ in Nitric-Acid Solutions." Radiochimica Acta 49:193-199.

Triay IR, DE Hobart, AJ Mitchell, TW Newton, MA Ott, PD Palmer, RS Rundberg, and JL Thompson. 1991. "Size Determinations of Plutonium Colloids Using Autocorrelation Photon Spectroscopy."

Radiochimica Acta 52/53:127-131.

Uetake N. 1991. "Chemical-state detection of dibutyl phosphate using P-31 NMR chemical-shift change.” Canadian Journal of Chemistry-Revue Canadienne De Chimie 69:322-326.

Unterweger MP, DD Hoppes, FJ Schima, and JS Coursey. 1992. Radionuclide Half-life Measurements. National Institute of Standards and Technology (NIST), accessed March 27, 2012 at http://www.nndc.bnl.gov/nudat $2 /$.

Veeramani H, DS Alessi, EI Suvorova, JS Lezama-Pacheco, JE Stubbs, JO Sharp, U Dippon, A Kappler, JR Bargar, and R Bernier-Latmani. 2011. "Products of abiotic U(VI) reduction by biogenic magnetite and vivianite." Geochimica et Cosmochimica Acta 75:2512-2528.

Waite TD, JA Davis, BR Fenton, and TE Payne. 2000. "Approaches to modeling uranium (VI) adsorption on natural mineral assemblages.” Radiochimica Acta 88:687-693. 
Wang P, A Anderko, and D Turner. 2001. "Thermodynamic modeling of the adsorption of radionuclides on selected minerals." Industrial \& Engineering Chemistry Research 40:4428-4443.

Watrous RA, DW Wootan, and SF Finfrock. 2002. Activity of Fuel Batches Processed Through Hanford Separations Plants, 1944 Through 1989. RPP-13489, Rev. 0, CH2M HILL Hanford Group, Inc., Richland, Washington.

Weimer WC. 1978. Isolation of Plutonium Physical-Chemical States from Natural Waters. PNL-2672, Pacific Northwest Laboratory, Richland, Washington.

WHC - Westinghouse Hanford Company. 1993. Results of Spectral Gamma Ray Logging of Select Boreholes for the 200 Aggregate Area Management Study. WHC-SD-EN-TI-021, Rev. 0, Richland, Washington.

White MD, M Oostrom, ML Rockhold, and M Rosing. 2008. "Scalable modeling of carbon tetrachloride migration at the Hanford Site using the STOMP simulator." Vadose Zone Journal 7:654-666.

Wilkinson KJ and JR Lead. 2007. Environmental Colloids and Particles: Behaviour, Separation and Characterisation. John Wiley \& Sons, Chichester, England; Hoboken, New Jersey.

WMP. 2005. Borehole Summary Report for Well 299-W15-46 (C3426) Drilled at the 216-Z-9 Trench. WMP-26264, Rev. 0, Fluor Hanford, Inc., Richland, Washington.

WMP. 2007. Borehole Summary Report for Well 299-W15-48 (C3427) Drilled at the 216-Z-9 Trench. WMP-30566, Fluor Hanford, Inc., Richland, Washington.

Zhang P and T Kimura. 2006. "Complexation of Eu(III) with dibutyl phosphate and tributyl phosphate." Solvent Extraction and Ion Exchange 24:149-163. 


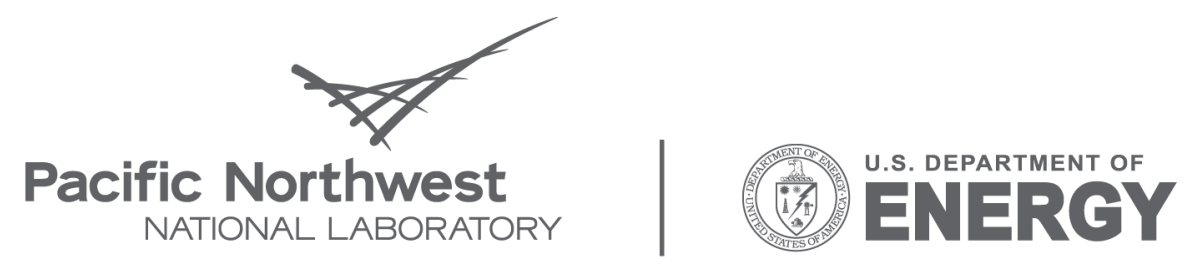

Proudly Operated by Battelle Since 1965

902 Battelle Boulevard

P.O. Box 999

Richland, WA 99352

1-888-375-PNNL (7665)

www.pnl.gov 